\title{
The Development of the Short Story in the South
}

\author{
A DISSERTATION
}

Submitted to the Faculty of the University of Virginia in Partial Fulfillment of the Requirements for the

Degree of Doctor of Philosophy

BY

ROBERT CECIL BEALE

Fredericksburg, $V a$.

THE MICHIE COMPANY, PRINTERS

Charlottesville, Virginia 1911

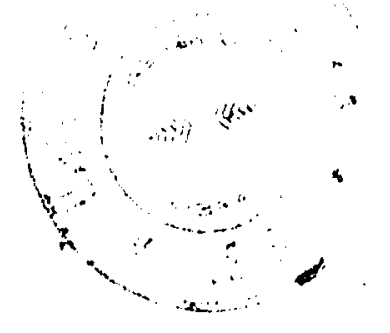




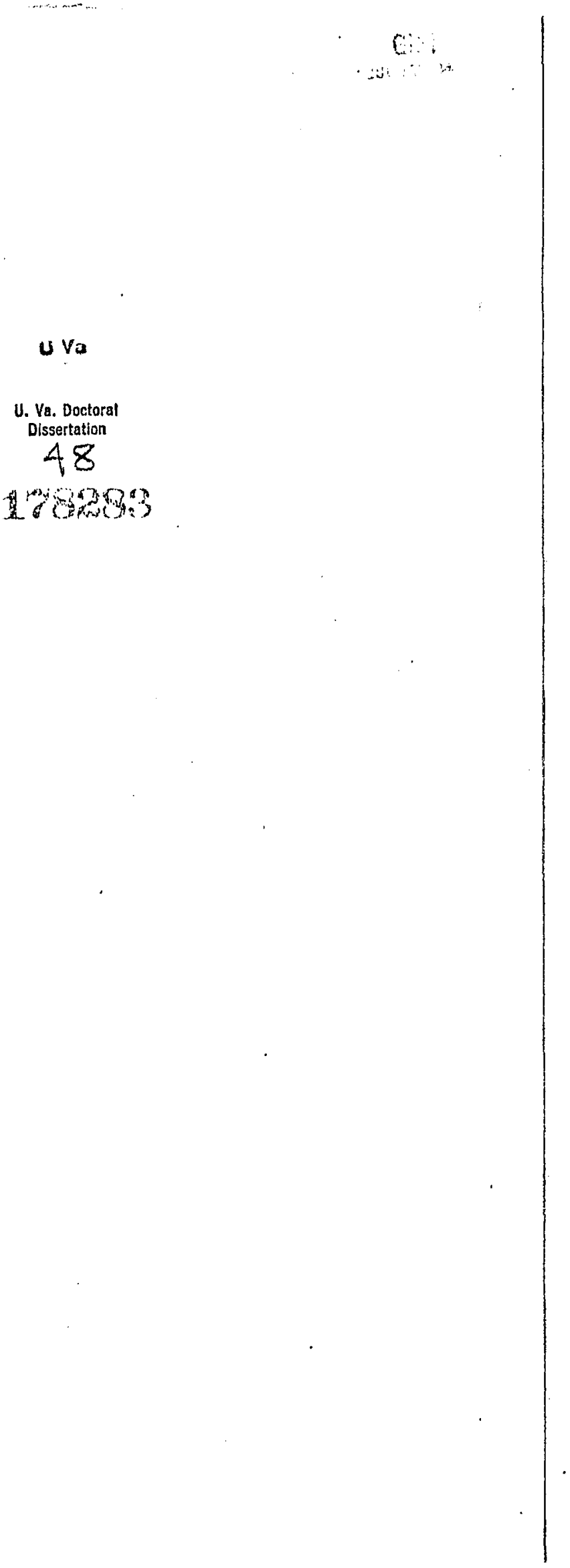




\section{PREFACE}

In regard to any piece of literary composition it is usually true that no one is more clearly conscious of defects and limitations than the author. The demands of his theme are so frequently and carefully reviewed by him and the investigations incident to his work so often yield results far below his expectations that there is little danger of his being too lenient a critic of his own achievement. In the present work much remains unaccomplished that the writer desired to perform. Accurate conclusions in many matters have not always been obtained; points of interest have elucled investigation; and facts have not always been at hand to stipport inferences that appeared reasonable. The result, imperfect as it is, is put forth with the hope that any merits that it may possess will enable it to be of some small service and that its defects will lead others to correction and improvement.

In the preparation of this work help and encouragement have been received from many sources. The sympathetic interest, the general guidance, and the critical assistance of Dr. Charles W. Kent are here gratefully acknowledged. Valuable criticisms and suggestions have also been furnished by Dr. Alphonso Smith, Dr. William Harrison Faulkner, and Dr. George A. Wauchope of the University of South Carolina, who was, during the latter part of the session of 1909-'10, temporarily filling the chair of English Literature in the absence of Dr. Kent.

The works of others along similar or related lines have greatly assisted in the preparation of this monograph. Among these I desire to acknowledge great indebtedness to the dissertation of $\mathrm{Mr}$. James Gibson Johnson of Charlottesville, Va. on "Southern Fiction Prior to 1860" and to an unpublished catalogue of Southern fiction from 1860 to 1908 prepared by him. The list of authors contained in this catalogue was exceedingly valuable as a general guide in my examination of magazines. Dissertations containing special points of information useful to me were also kindly-furnished by Dr. Gustav Gruener of Yale University, Dr. Palmer Cobb of the University of North Carolina, Dr. Scott H. Goodnight of the University of Winconsin, 
and by Dr. William Cairns of the University of Wisconsin. Other works that have been consulted are mentioned in the bibliography.

Authors to whom letters of inquiry have been addressed have kindly furnished much helpful information. For such letters acknowledgment is due to Dr. William P. Trent of Columbia University, Mr. Hamilton W. Mabie of New York, Mr. George W. Cable of Northhampton, Mass., Mrs. Ruth McEnery Stuart of New York, Mr. Harry Stillwell Edwards of Macon, Georgia, Mr. John M. Elliott of Portland, Oregon, Mrs. Attwood R. Martin of Anchorage, Ky., Miss Lotise Preston Looney of Memphis, Tenn., Mrs. LaSalle Corbell Pickett of Baltimore, Md., Mr. Jas. L. Easby-Smith of Washington, D. C., Mr. William Perry Brown of Glenville, W. Va., Miss Kate Slaughter McKinney of Montgomery, Ala., Mr. L. C. Whitlock of Baltimore, Md., Mrs. Clark Waring of Columbia, S. C., Miss Evelyn Snead Barnett of Lotisville, Ky., and Miss Annie Booth McKinney of Knoxville, Tenn.

In the libraries from which the material for this dissertation has been gathered uniform courtesy has been shown by the officials and many special favors granted. The author's thanks are therefore due to the officials of the library of the University of Virginia, the Virginia State Library and the Confederate Library of Richmond, Va., the Library of Congress in Washington, and the library of Fredericksburg, Va.

\section{Miller School, Va.,}

Robert C. Beale.

May IO, IOII. 


\section{Contents}

CHAPTER PAGE

Preface . . . . . . . . . . . . . . . . . III

INTRODUCTION . . . . . . . . . . . . . . 1

I. The Short Story in the South before 1833 . . 7

II. Poe and the Short Story . . . . . . . . . 12

III. The Tales of the Southern Magazines and NeWSPAPERS From 1834 to 1860 . . . . . . . 25

IV. The Period of, Transition-1860-1870 . . . . 47

V. The Southern Renaissance . . . . . . . . 50

VI. Stories of "Cracker" Life . . . . . . . . . 53

VII. Stories of Creole Life . . . . . . . . . . 58

VIII. Stories of Negro Dialect and Character . . . 64

IX. The Mountaineer Story . . . . . . . . . 76

X. The General Field . . . . . . . . . . . . 82

Short Story Writers of the South . . . . . . . 91

Periodicnls Containing Short Stories by Southern Writers . . . . . . . . . . . . . . . 99

Chironological List of Southern Short Stories Writ-

ten in the Nineteenth Century . . . . . . . . 101

Supplementary List of Coliections of Short Stories of

Which the Dates of Publication Could Not Be

Ascertained . . . . . . . . . . . . . . . 135

BIBLIOGRAPHY . . . . . . . . . . . . . . . 136 


\section{INTRODUCTION}

It is the purpose of this monograph to trace the development of the short story in the literature of the Southern States from 1833 to the end of the nineteenth century. Two reasons may be noted for the selection of the former date. The year 1833 marks the rise of the modern short story in the work of Poe, and also furnishes an approximate date for the beginning of popular periodical literature in the South. ${ }^{1}$ The relation between the growth of the short story and the modern magazine makes it important to study the history of the one in its chonological connection with the other. Professor Canby is without doubt correct in asserting that the short story and the modern magazine may each in turn be regarded as the cause and effect of the other, a statement amply verified in the history of every modern literature in which the short story has been extensively cultivated.

The condition of Southern fiction in the form of the short story antecedent to Poe will be briefly reviewed as far as will be essential to the purpose of the present work. The close of the nineteenth century has been selected as the end of the period to be studied for obvious reasons. By the end of the century the sectional influences that have given Southern literature its special characteristics, which clearly differentiate it from that of other sections of the country, had exerted their full force, and had begun to show signs of abatement. By the end of this period, the special forms of the short story typical of the South had attained their full development. Thenceforward the literature of the South was to display less of local peculiarity, and to share more in the general national character.

The century falls naturally into two main periods, separated by the sharply dividing line of the Civil War. The effect of this conflict on the material and the spirit of the Southern short

1. The Cosmopolitan, Charleston, S. C., 1833. The Southern Literary Messenger, Richmond, Va., 1834. The Southern Literary Journal, Charleston, S. C., 1835. 
story will be the leading fact to be taken into account in the study of the second period.

The limits of the period to be studied being thus defined, it becomes necessary to add two words of explanation with reference to terms employed in the theme. In the first place, it is important to make clear the exact sense in which the term short story is to be used in these pages. The recent discussion of this type of fiction has given rise to a considerable body of literature in the form of magazine articles and separate volumes devoted exclusively to it. ${ }^{2}$ These discussions have revealed some divergency of opinion as to the precise character and limits of the short story. It is therefore important to note the present application of the term.

The term short story has two meanings. In a loose, general sense, it is used to cover any form of brief narrative. Used by the literary critic of today with reference to the form of the short story that has been typical of the nineteenth and twentieth centuries, it designates a highly compact and unified brief narrative so planned and proportioned as to leave upon the mind of the reader a single definite impression.

The slight vagueness in the application of the term is to be explained by the history of the development of the short story as a literary form. Brief narratives have always existed since human expression began. Until the nineteenth century, however, literary usage recognized no essential distinction between the longer fiction classified roughly as novel and romance and the short tale except that of length. Strictly speaking, as fiction was then composed, there was no other distinction. During the third decade of the nineteenth century, however, a new ideal of the short story began to embody itself in the work of Poe and

2. Albright, Evelyn May; "The Short Story," Macmillan, 1907. Barrett, Chas. Raymond; "Short Story Writing," Baker, 1900. Canby, Henry Seidel; "The Short Story in English," Henry Holt, 1909. Hart, W. M.; "Hawthorne and the Short Story," Berkeley, Cal., 1900. Matthews, Brander; "The Philosophy of the Short Story," Longmans, 1901. Quick, Leslie W.; "How to Write a Short Story," Editor, 1904. Smith, Lewis Worthington; "The Writing of the Short Story," Esenwein, J. Berg; "Writing the Short Story," Hinds, Noble \& Eldredge, 1908. 
Hawthorne in America, Mérimée, Balzac and Gautier in France. In a word, the artistic possibilities of the story that was short began to be fully realized. Substituting for the looseness of the older tale a compactness and brevity of structure, confining the attention closely to a single incident, and proportioning the narrative so as to give this incident a climactic effect conveying a definite impression, the writers just named may be said to have begun a new type of the short story. Since then literary critics have chosen largely to confine the term short story to this special type and to employ the term tale to designate brief stories of looser form not obeying these rigid principles of technique. $\mathrm{Mr}$. Esewein, editor of Lippiniott's Magazine, thus defines the two forms: ${ }^{3}$

"A Tale is a simple narrative, usually short, having little or no plot, developing no essential change in the relation of the characters, and depending for its interest upon incidents rather than upon plot and the revelation of character."

"A Short Story is a brief narrative unfolding a single predominating incident and a single character; it contains a plot, the details of which are so compressed and the whole treatment so organized as to produce a single impression."

Now these definitions cannot, as Mr. Esenwein admits, be applied with rigid exactness in classifying specimens of brief narrative. Indeed, in discussing the historical development of the short story it is necessary to give the term a broader application, while recognizing the fact that the definition covers one type of short story; namely, that chiefly in vogue today.

In deciding whether the modern short story shall be classified as a distinct type, the most reasonable view of the question is, as it seems, to take the ground assumed by Prof. Bliss Perry. ${ }^{4}$ Although he admits the distinction between the modern short story and the older tale, it is, in his opinion, best explained as a different attitude of the author toward his material. This is about equivalent to saying that, after all, the real difference in the method of the modern short story consists in the fact that the writers have shown greater condensation, more effort after

3. "Writing the Short Story," by J. B. Esenwein, pages 26 and 30 .

4. "A Study of Prose Fiction," by Bliss Perry. Chapter on the Short Story, page 303. 
unexpected conclusions and striking impressions, more sublety of suggestion, a keener sense of situation, and more skillfull use of local color. In a word the modern short story has resulted from the application of higher art to a form which in essential features has always existed. The change has been a matter of literary technique.

The true difficulty in the discussion of the short story is, after all, not a question of analysis and definition, but of terminology. The confusion is due to the arbitrary insistence that the term short story, which is, by its nature, a generic term, shall be confined to one species. The suggestion of Prof. Brander Matthews that the hyphenated spelling of the term be employed to designate the modern form of the short story has not found general acceptance. ${ }^{5}$ Professor Canby, in his preface to his recent work, "The Short Story in English," makes use of a distinction which practically solves the difficulty. ${ }^{6}$ He differentiates the historical and rhetorical uses of the term. By this distinction he explains his discussion of many short narratives which, according to modern standards, are not short stories, and yet are a part of the historical development of the form. It is in the historical sense that the term will be frequently used in this monograph.

Two forms closely allied to the short story, the sketch and the anecdote, are to be distinguished from it. The sketch differs from the short story in the fact that the author's purpose is primarily description, rather than narrative. When an incident is related in the sketch, it is not the central point of interest, but is merely one of the details of a picture. In a short story the incident related must be the very kernel of the work. The interest may appear to center in the character, but it must be an interest in the character as revealed by that incident and not apart from it. ${ }^{7}$

In defining the anecdote, Mr. Wm. Dean Howells says: "It offers an illustration of character or records a moment of action." 8

5. "The Philosophy of the Short Story," p. 24.

6. Pages VI and VII.

7. On distinction between short story and sketch, see Esenwein's "Writing the Short Story," page 25.

8. "Some Anomalies of the Short Story," North American Review, Sept., 1901. 
Its motive is thus seen to be simpler than that of the short story, and it is practically without plot. It shows greater brevity and suppression of details; not, however, for the sake of securing greater unity and singleness of impression, as in the short story, but because the incident is simple and is to be kept unincumbered in order that its point may be properly felt.

One question remains for consideration by way of introduction. Has the Short Story in the South shown characteristics sufficiently distinctive to justify separate treatment? It is generally conceded that the South has produced a literature which should be studied apart from the general literature of the country if it is to be rightly understood and appreciated. Prof. Carl Holladay, in his "History of Southern Literature," says: "When in the development of a nation the extent of territory inhabited by that people becomes so great as to preclude a mutual understanding of diverse customs and feelings of the various sections, it is but natural and, indeed, necessary that such a commonwealth should have more than one type of literature and that these types should be in many traits exceedingly different."

From the beginning of the Colonial Period influences were at work in the South which tended to produce a civilization quite distinct from that of other sections of the country. The differences, instead of diminishing with establishment of the Republic, were augmented by the grave political issues which were soon forced upon the attention of the nation. When the time came for an adequate literary expression of Southern life, the mental attitude of her writers, as well as their field of work, was entirely distinct from that of the nation at large. For these reasons, it appears that the Southern short story justly deserves separate consideration.

The short story in the South has displayed individual characteristics both in theme and treatment. To understand the various phases of life described, to catch the spirit of the setting, to sympathize with the ideals and sentiments embodied in the characters, requires an understanding of the conditions in which this fiction grew. In treatment, on the other hand, the Southern short story has been characterized by simplicity of plot, natural-

9. Preface, p. 13. 
ness of action, warmth of imagination, genuine feeling, tender pathos, racy wit and humor. The Southern writers of the short story in the period since the Civil War have been almost literal transcribers from life. If there has been tragedy, pathos or humor in their work, it is because these elements existed in the life that they knew and described. They have at all periods been singularly free from the chilling touch of artificiality, and have shown an utter distaste for reveling in the ugly, exceptional and morbid phases of life. ${ }^{10}$

Mr. Hamilton Mabie made a sound generalization when he said of the later school of Southern writers: "Their work comes from the heart rather than from the analytical faculties."11 In concluding this introductory chapter, we may fittingly add the criticism of Prof. Pancoast: ${ }^{12}$

"These Southern story-writers have done more than give us studies of new localities; we feel instinctively a different quality in their work. If we contrast it with the productions of New England, intellectual, self-examining, self-conscious, we feel the richer coloring, the warmer blood, the quicker pulses of the South. Read the most characteristic of Hawthorne's stories, and then turn to the "Marse Chan" or "Meh Lady" of Thomas Nelson Page. It is like passing from the world of thought to the world of action, from the analysis of life to living. . . . . . . It is a world to be alive in, a young world, where men are full of knightly courtesies and knightly courage, and where women are good and fair. Put a book of Cable's beside a keen and clever study of Howells's and it is like the tropic warmth of the Gulf Stream after the chill of Northern Waters. . . . . . Whatever else this Southern literature may be, at least it is different."

10. Poe is an exception to this statement. The entirely unmoral character of his work, however, prevents it from having any force as ethical teaching. A slight tendency to unhealthy sentiment is to be traced also in some of the Southern magazine stories in the antebellum period. This was, however, a general failing of periodical literature in the first half of the century.

11. Burlington (Vt.) Magazine.

12. Introduction to American Literature, p. 320. 


\section{CHAPTER I}

The Short Story in the South before 1833

In the introduction to Professor Baldwin's "American Short Stories" an admirable statement is given of the general state of the tale in America before the thirties. Speaking of this period, he says: ${ }^{1}$

"The significance of the short story as a new form of fiction appears on comparison of the staple product of tales before 1835 with the staple product thereafter. 1835 is the date of Poe's 'Berenice.' ${ }^{2}$ Before it lies a period of experiment, of turning the accepted anecdotes, short romances, historical sketches, toward something vaguely felt after as more workmanlike.' This is the period of precocious local magazines ${ }^{3}$ and of that ornament of the marble-topped tables of our grandmothers, the annual. Various in name and color, the annual gift-books were alikeexternally in the profusion of design and gilding, internally in serving up, as staples of their miscellany, poems and tales."

As Professor Baldwin here intimates, the "staple product" in tales from these two sources, the magazine and the annual, was, in spite of the abundance of these publications, entirely ephemeral in character.

It seems safe to assert that in this body of fiction there was no promise of the later short story beyond a growing interest in

1. Page 2.

2. Prof. Baldwin selects this year as his starting point because "Berenice" marks definitely the beginning of the modern method in the short story. In the present treatise, 1833 is chosen as the beginning of the period because Poe's first published story appears in that year.

3. See Prof. N. B. Cairns' "On the Development of American Literature from 1815 to 1833 , with Especial Reference to Periodicals." Bulletin of the University of Wisconsin, Philology and Literature Series, Vol. 1, No. 1, pp. 42-44. Prof. Cairns cites 135 periodicals founded in America between 1815 and 1833 . Not all of these, of course were mediums for the publication of fiction. $\mathrm{He}$ names also eight annuals, a part of the number appearing in 1829 alone. 
American character and scenery manifested in a fondness for depicting some phase of local manners through a bit of history or popular legend. It is here that the popular tale of the day shows its connection with Irving, and it is in his work alone that we find truly artistic specimens of the tale in America before the thirties.

Irving's influence upon the development of the short story in America was not in proportion to the charm and interest of his own work. He had brought the leisurely tale to a point of artistic excellence hitherto tnattained, but his work did not point clearly in the direction of the modern short story, nor did the direct imitation of his style and method contribute perceptibly to the development of the form. ${ }^{*}$ On the contrary, his special type of narrative in less skillful hands usually resulted in intolerable dullness, a fact which serves to account, in some measure, for the tedious character of the magazine tale in the early years of the last century.

This brief statement will indicate sufficiently the degree of progress attained by the American short story at this period outside of the Southern states. The output in Southern fiction prior to 1833 is small." This is particularly true in the department of the short story. In 1832, Joln P. Kennedy of Baltimore had shown the infuence of Irving in his "Swallow Barn," a connected series of sketcles following the general manner of "Bracebridge Hall." None of these sketches attains the form of a distinct tale more closely than the story of "Abe," the negro sailor lost in a storm, a strong descriptive sketch, with an element of plot. ${ }^{0}$

Other attempts in fiction had preceded Kennedy's work. In 1821, Tobias Watkins (1780-1855) of Maryland issued in Baltimore "Tales of the Tripod; or a Delphian Evening. By Pertinax Placid." 7 Isaac Edward Holmes published in Charleston, S. C., in 1822, "Recreation of George Telltale," a series of essay stories

4. Cairns: On the Development of American Literature from 1815 to 1833, p. 64 .

5. See Jas. Gibson Johnson: Southern Fiction Prior to 1860 . University of Va., 1909.

6. Swallow Barn, pp. 461-490.

7. Johnson: So. Fict. Prior to 1860 , p. 100. 
and descriptive sketches. ${ }^{8}$ "Anecdotes of the Revolution,"9 (1822) by Alexander Garden (1757-1829) of Charleston, S. C., show some humor and sprightliness in the telling of simple incidents. In 1824 "The Tales of an American Landlord, Containing Sketches of Life South of the Potomac,"10 appeared anonymously. Between 1830 and 1835, Alexander Dimitry of Louisiana contributed several short stories to annuals under the name of "Tobias Guarnerius."

At this time, the literary conditions in the South were peculiarly disadvantageous for the production of the short story. Foremost among the obstacles may be mentioned the scarcity of periodicals. The few magazines that were then issued in the South gave little encouragement to fiction. The Visitor, ${ }^{12}$ Richmond, Va., first issued Feb. 11th, 1809, stated in its prospectus that the magazines of the South were all of a political complexion, and it announced its intention of being more broadly literary. The conditions here intimated did not change materially in the years immediately following. Such publications as The Evangelical and Literary Magazine, Richmond, Va., (1821) occasionally contain a tale, tediously moral. Of the magazines named by Dr. Reinhold Rogers in his monograph, ${ }^{13}$ none before the Southern Literary Messenger (1834) issued any large amount of fiction. The Western Review, Lexington, Ky., (1820), The Tablet, Charleston, S. C., (1828), and The Cosmopolitan, Charleston, (1833) were among the few that were issuing fiction at all. In fact, the Southern magazines at this period served chiefly as a medium of expression of the literary critic and the political essayist. The Southern Reviere, founded in Charleston, S. C., in 1828, is representative of this class of periodicals. Modeled after the solid English reviews of the period and containing only matters of great pith and moment, it illustrates forcibly the general character of the Southern periodical literature of the time.

8. Johnson: So. Fict. Prior to 1860, p. 39.

9. Carl Holladay: History of Southern Literature, p. 155.

10. See Evang. and Lit. Rev.

11. Johnson: So. Fict. Prior to 1860, p. 24.

12. Virginia State Library.

13. "Four Southern Magazines," University of Va. 
A second condition then unfavorable to the short story in the South is to be found in the literary tastes of the time. Literary opinions in America, and especially in the South, still closely followed those of England. ${ }^{14}$ In England the three volume novel was the form of fiction that chiefly commended itself to public taste. The cultivated classes in the South found their reading matter in the Elizabethan classics, the poets and essayists of the eighteenth century and the recent Romantic literature. ${ }^{16}$ A limited circulation of British periodicals supplied them with contemporary thought and opinion. In this condition of literary taste, there was little influence favorable to the production of short tales.

Attention has been frequently called to the existence in the Old South of certain feelings of prejudice against literature as a profession. It can hardly be doubted that this prejudice operated more strongly against the cultivation of the lighter types of literary work than those which appealed to the more scholarly tastes. The production of tales could, therefore, scarcely be regarded as an exercise worthy of the best literary talent, which at that time found vent in the moral or political essay, or in disquisitions of a profound and learned character.

Lastly, there was among the Southern writers of that time a lack of the precise literary training necessary to qualify them for handling this difficult type of fiction. Of all forms of prose composition, the short story is the one in which execution counts for most. Although there was among the cultivated classes of the South an intense appreciation of pure literature and an acceptance of the best standard, there was an absence of the strict literary discipline necessary to enable the writer of tales to master the technical difficulties of his art. This was then in large measure true of American authorship in general. The isolation of Poe and Hawthorne in this special field of fiction shows how inadequately equipped were the mass of literary craftsmen of that time for the successful handling of the short

14. See the criticisms of American literature in the magazines of that period and even later.

15. On literary taste in Virginia at this period, see "The Old Régime in the Old Dominion," by George Carey Eggleston, Atlan, Mo., Nov., 1875. 
story. Writing nearly ten years later in Graham's Magazine, ${ }^{10}$ Poe was forced to say that America had produced few tales of merit except those of Irving and Hawthorne (his own would, of course, be added), and in subsequent criticisms, when he felt called upon to give praise to a tale, he ustually bestowed it upon the rare and much needed quality of constructiveness. ${ }^{17}$

To sumniarize briefly the points of the chapter, it may be said that Southern literature prior to 1833 contains no short tales of decided merit; that the sketches of John P. Kennedy were the best of their class produced in this section; that the causes then unfavorable to the production of the short story in the South were the scarcity of perioclicals, the state of literary taste, the prejudice against professional authorship, and the lack of technical training in the writers of the period.

16. Criticism of "Twice Told Tales," Graham's Magazine, May, 1842.

17. Comments on story writers in "The Literati of New York City."

$-2$ 


\section{CHAPTER II}

\section{POE AND THE SHORT STORY}

All the facts connected with the publication of Poe's stories have been abundantly set forth in the numerous biographies of this atthor. ${ }^{1}$ The purpose of this study demands only a summary of these facts as an introduction to the discussion of his place in the development of the short story.

Poe's apprenticeship in prose fiction began, as far as all the testimony goes, while he was a student at the University of Virginia in 1826.

No record is preserved of the exact plot of any of these stories, which delighted his college friends, nor is it known whether any of his later published tales had then taken shape in his mind. The history of his development as a story writer is a blank from this time until 1833 , when he won the prize of $\$ 100$ offered by the Baltimore Saturday Visitor with the tale, "The Ms. Found in a Bottle," which appeared in the number for October 12th. ${ }^{2}$ At this time he had on hand six or eight tales, one of which was "A Descent into the Maelstrom,"3 and to these tales he had given the general title "Tales of the Folio Club."

This collection, supplemented by other tales, was offered to the publishing house of Carey and Lea, of Philadelphia, in 1834. Finally, upon the recommendation of Mr. John P. Kennedy of Baltimore, Poe sent to Thos. Willeys White, the proprietor of the Southern Literary Messenger, in Richmond, Virginia, some of the "Tales of the Folio Club." appeared in the Messenger for March, 1835. By the summer of $1835, \mathrm{Mr}$. White had offered Poe employment upon the staff of the magazine. ${ }^{0}$ Leaving Baltimore he entered upon his duties as

1. Harrison, Woodberry, Lauvriere, Joyce, Link, Gill and others.

2. Harrison: Edgar Allan Poe's Work, Vol. 1, p. 101.

3. Reminisciences of Poe by John H. Latrobe. Edgar Allan Poe. Memorial Volume, by Sara Sigourney Rice. Turnbull Bros., Baltimore, 1877.

5. Harrison: Works of Edgar Allan Poe, Vol, 1, p. 113, 116.

6. Harrison: Works of Edgar Allan Poe, Vol. 1, p. 116. 
assistant probably in the early fall, although he was not editor until December. ${ }^{7}$ His connection with the magazine as editor ended with the December number of 1836.

The stories contributed by Poe to the "Messenger" were "Berenice" (March, 1835), "Morella" (April), "Some Passages in the Life of a Lion" (May), "The Unparalleled Adventures of One Hans Pfaall" (June), "The Assignation" (July), "BonBon" (August), "Shadow: a Parable" (September), "Loss of Breath" (September), "King Pest" (September), "Metzengerstein" (January, 1836), "The Duc de L'Omelette" (February, 1836), "Four Beasts in One" (March), "A Tale of Jerusalem" (April). These tales just named, together with the "Ms. Found in a Bottle" (Balto. Sat. Visitor, Oct. 12, 1833), "Silence; a Fable" (Balto. Book, 1839), "A Descent into the Maelstrom" (Grahan's Magasine, May, 1841) are believed to have been the sixteen "Tales of the Folio Club." $\$$ The tales also formed, a part of the "Tales of the Grotesque and Arabesque." 9 The two volumes of this work contain in all twenty-five stories.

The further steps of Poe's progress in fiction need not be traced in detail. Continuing his work in Philadelphia and New York, he showed a further development of motives; new studies of supernatural agency; as in "The Fall of the House of Usher" (Burton's Gentleman's Mag., Aug., 1839); dual personality in "William Wilson" (Burton's Gentleman's Mag., Oct., 1839); solution of mystery in "The Murders of the Rue Morgue (Grahan's Mag., April, 1841) and "The Mystery of Marie Roget" (Snozvden's Lady Companion, Dec., 1842); new pictures of horror in "The Masque of the Red Death" (Graham's Mag., May, 1842); "The Pit and the Pendulum:" (The Gift, 1843), and "The Black Cat" (The Phil. U. S. Sat. Post., Aug. 19, 1843); acute analysis of facts in "The Gold Bug" (Phil. Dollar Nez'spaper, June 21-28, 1843 ) and "The Purloined Letter" (The Gift, 1845); the cloctrine of metempsychosis and hypnotism in "A Tale of the Ragged Mountains (Godey's Lady's Book, Apr., 1844) and "The Facts in the Case of Mr. Valdemar" (American Whig Reviezu, Apr., 1845).

7. Rogers: Four Southern Magazines, p. 99.

8. Harrison: Works of Edgar Allan Poe, Vol, 2, p. XXXV.

9. Woodberry: Edgar Allan Poe, pp. 115-116. 
The following points are now to be considered: Poe's influence in the development of the short story; his indebtedness to outside sources.

In the Introduction the distinction that is now usually made between the short story and the tale was noted, and the chief characteristics of the modern short story were there briefly set forth. We shall now proceed to show, in the first place, that before Poe began his work there was in the main no reason for making this distinction; next, that Poe more fully than any other writer of his time conscionsly cleveloped the modern method; and finally, that his method, which he not only practiced consistently, but expounded clearly, has been the most potent single influence in the development of the form.

Professor Baldwin, in his introduction to "American Short Stories," has traced the development of the tale through ancient and modern times down to the modern French short story. $\mathrm{He}$ has shown that although rarely, as in the Decameron of Boccaccio, there are found tales which can hardly be distinguished from the modern short story, the achievement was, so to speak, accidental, and not the result of conscious contrivance, nor was it influential in establishing a method. He has also shown that neither Nodier nor Mérimée established firmly in France the modern form of the short story. Nodier, like Hawthorne, his supposed disciple, shows decided tendency to the descriptive essay and the moralizing tale. Mérimée's pieces most distinguished by conciseness are in reality descriptive anecdotes and lack the focusing of details that characterizes the short story. "La Venus d'Ille" is his one definite and perfect example of the short story.

From these conclusions of Professor Baldwin we note that before Poe began his work no writer of short stories had displayed a firm grasp of the full possibilities of the brief narrative for securing unity of effect and intensity of impression. Here and there a writer had in isolated specimens of his work attained a compactness and brevity of structure which resulted in practical unity of impression. Poe, on the other hand, from the very beginning of his work, consciously developed a method for securing this result and consistently followed it to the end. Basing his practice upon this theory of the tale, which he later set forth in his criticism of Hawthorne, he began by cutting away the 
usual delaying introduction and rigidly excluding every detail that did not bear directly on the conclusion. Then with deliberate art he proceeded to harmonize the tone of the narrative. Not a detail was admitted that was not in keeping with the spirit of the whole. With minute attention to the value of the specific term, he set the example for the modern accentutation of the mood of the story and the intensifying of an emotional situation. No less skill does he display in graduating to a climax the incidents of a story of action. $\dot{F}$ urthermore, these principles of his technique were displayed with deliberate intent and sureness of touch in the early group of stories appearing in the Southern Literary Messenger. "By 1836," says Professor Baldwin, "Poe knew his art; he had only to refine it."10

Poe and Hawthorne are usually classed together as the originators of the short story in America. A careful comparison of their work, however, will show that Poe displays at all stages of his work a more distinct consciousness of the form that the short story should take. Hawthorne, who far outweighs Poe in ethical value, does not show the same definiteness of conception and sureness of touch on the purely structural side of his work. Professor Canby has stated that Hawthorne's chief contribution to the development of the short story was his emphasis of situation as a motive for brief narrative, ${ }^{11}$ and that Poe's, on the other hand, was the perfecting of the technique of the short story to convey an intense impression. ${ }^{12}$ It would seem, perhaps, more exact to say that Hawthorne's situations are of far greater moral import than Poe's, and hence secure for themselves an increase of emphasis. The essence of Poe's method is in reality a concentration upon the clenouement. The situation there portrayed is usually one of horror, not of moral significance, but the lesson he thus taught in the principles of short story construction is a more definite one than Hawthorne's, since the latter sometimes blurs the effect of his situation by a moralizing conclusion.

To state briefly the true significance of Poe's achievement, we quote Professor Canby, who says: "He (Poe) succeeded in his

10. "American Short Stories," p. 22.

11. Canby: "The Short Story in English," pp. 260-261.

12. "The Short Story in English," pp. 261-262. 
attempt by fixing the attention on the climax of the story, usually some outward sign of horror, such as Berenice's teeth, the physical terrors of the Antarctic, or the fall of the House of Usher, and always with the result that the reader sees, feels, thinks of the unique effect of the story and of nothing else. If the modern short story has a technique here it is; if it is an invention, Poe invented it."13

The method which Poe thus brought into use has been in the main the method used by the skillful short story writer ever since. Poe's explanation of his method has been without doubt the most influential single statement that has been made upon the subject. It has been quoted by every writer upon the short story, and has been made the basis of practically every exposition of the form. Furthermore, Poe was the founcler of the modern detective story; he was the first to employ scientific facts in fiction, and by his method of analysis, he set the example for the story involving the solution of mystery.

Poe's influence upon the short story in the South is not to be traced in the work of any immediate successor. He aroused no following. He had attained so high a standard that few were tempted to follow where imitation would be weak and immediately detected. His field, moreover, was not entirely congenial to Southern temper, which has shown a strong tendency to shun the morbid and weird and to maintain a healthy and natural tone. A few imitations of his manner can be traced in isolated cases. Mrs. Catharine Warfield attempted some imitations of his style, which never appeared in print. ${ }^{14}$ Some likeness to Poe may be observed in a few of Grace Elizabeth King's "Stories of Time and Place." Perhaps a few magazine tales that are to be noted later may owe some of their gloom to Poe, but his subtile touch is never felt again in Southern literature in his special field. $\mathrm{He}$ has not materially affected the Southern short story in general mood nor in the choice of material. His influence has been felt only in the obedience to the principles of short story structure, which, as we have seen, received their clearest definition from

13. Canby: "The Short Story in English," p. 237.

14. "Tales of the Weird and Wonderful." See Tardy's "Southland Writers," p. 36. 
him. The extent to which these principles have guided the writers of the New South will be noted in the later pages of this work.

We come now to the consideration of Poe's indebtedness to outside sources. None of these influences, except the German, needs special attention. This will be treated only as it bears directly on the present theme.

The true extent of Poe's indebtedness to German sources seems to be fairly represented in the words of Professor Canby: "To say that Poe was a creature of German influence would be absurd. To say that German thought and fancy were sympathetic to his genius would be putting it too mildly. Between these extremes the truth must lie."15

Dr. Gustav Gruener of Yale and Dr. Palmer Cobb of the University of North Carolina have written monographs on Hoffmann's inflience upon Poe. ${ }^{10}$ Dr. Gruener in another paper also discusses Poe's knowledge of German. ${ }^{17}$ These papers appear to be successful in establishing the fact that Poe was indebted to Hoffmann for the motives of some of his stories. They establish nothing beyond that. Dr. Gruener's paper also seems to furnish strong evidence for the belief that Poe acquired at some time during his life a reading knowledge of German. Two questions suggested by these papers will now be considered. First, did Poe owe to German any lesson in the structure of his tales? Second, at what time did his study of German begin?

Dr. Cobb has shown the points of resemblance in the following tales by Hoffmann and Poe: "Die Elixiere des Teufels" and "William Wilson;" "Der Magnetiseur" and "A Tale of the Ragged Mountains ;" "Die Jestitkirche in G-" and "The Oval Portrait;" "Doge and Dogaressa" and "The Assignation."18

A comparison of the first two will make clear the point we desire to emphasize. The conclusions reached will apply with

15. "The Short Story in English," p. 230.

16. "Notes on the Influence of E. T. A. Hoffmann upon Edgar Allan Poe," by Gustav Gruener. "The Influence of E. T. A. Hoffmann on the Tales of Edgar Allan Poe," by Palmer Cobb.

17. "Poe's Knowledge of German," by Gustav Gruener.

18. "Influence of E. T. A. Hoffmann on the Tales of Edgar Allan Poe." 
equal force to the others. "Die Elixiere des "Teufels" is a long story in several chapters describing the life of the monk Medarus, who is beset so fiercely by temptation that he is driven from the monastery into a life of crime and misery. The inception of evil is traced to his drinking certain wine kept in the monastery among the relics of which he was custodian. This wine had been received from the devil by St. Anthony when tempted in the wilderness. The character who appears as the double of Medarus is in reality his half brother, Graf Viktorin, who, becoming insane, imagines himself to be the monk Medarus. Thus an entirely natural explanation is given of the supposed double existence. How essentially different is the story of "William Wilson." Poe commits himself absolutely to the theory of the double existence. It is the whole point of his story. By reducing his narrative to brief limits and concentrating attention on the crucial scene in the development of his character, he moves rapidly and with intensifying emotional effect to a striking climax. In a word, he produces a short story and this is precisely what Hoffmann does not do. Here we come upon that quality in Poe's genius which chiefly distinguishes him from other writers of tales in his time. It was his gift to see the elements of a situation which made it proper material for a short story, and then to incorporate this situation in a narrative structure of exactly the right proportions to secure the carefully designed effect. Granting his indebtedness to Hoffmann for some suggestions of motive, what he clearly did not learn from Hoffmann was how to construct a short story.

We come now to the second question: If Poe studied German, when did he begin it? The bearing of this question upon the extent of Poe's indebtedness to German will later be made clear. Professor Gruener endeavors to prove that Poe studied German while he was at the University of Virginia in 1826.10 His line of argument is as follows: Although there is no definite statement of the fact that Poe studied German at the university, he was then enrolled in the department of modern languages in which German was taught. His chief instructor was Professor Blaetterman, an accomplished German, whose influence on Poe is perceptible. Poe's entrance into the university took place just at

19. "Poe's Knowledge of German," p. 3. 
the time when the modern interest in German, particularly of the Romantic school, was beginning. Poe's ability was equal to the task of acquiring rapidly a reading knowledge of German. From the foregoing evidence Dr. Gruener reaches the conclusion that: "It does not seem an unwarranted assumption that Poe availed himself of the opportunity and studied German, either in the classroom or outside." 20

Now it will be observed that this agreement has weight only when combined with the general conclusion that Poe shows evidence in his later work of a reading knowledge of German. Professor Gruener reaches this conclusion through Poe's repeated references to German, his acquaintance with the spirit of the language, his knowledge of certain German idioms, and his apparently original translation of several German passages. Having reached this conclusion as to Poe's knowledge of German, the inference that he began this study at the University of Virginia does not seem to Professor Gruener an "unwarranted assumption." We think, however, it can be shown that the assumption is, perhaps, unwarranted, since certain evidence seems to point very strongly to the conclusion that Poe did not study German while at the University of Virginia. The purpose of this line of investigation will at once become evident when the fact is recalled that Poe had begun at the university to compose stories which bore plainly the marks of his later work. It is, therefore, important to discover whether German influence had begun at this period either directly through a reading knowledge of the language or through translations.

The stories just referred to are described in a paper in the University of Virginia Magazine based upon the recollections of Mr. Thomas Goode Tucker, Poe's most intimate friend at the university. 21

"They were," says the writer of this article, "mostly stories characterized by the same weirdness of style, graphically picturing horrible scenes and incidents that strongly marked all his published writings. His little room on West Range was often filled

20. Page 3.

21. University of Va. Mag., Vol. XIX, p. 431. Old Oddity Papers. By Douglas Shirly. These papers contain the substance of $\mathrm{Mr}$. Tucker's letters to him. 
with a small select audience of his most particular friends, who, spellbound, scarcely breathed while they eagerly listened to some story-strange and weird like all the rest-that he had just written and that he read with his whole soul thrown into every action and intonation of his voice-now loud and rapid like the mad rush of many waters, and now sinking into a scarcely audible whisper, of some terrible sentence of incantation or curse sending a shiver over all that heard."

This description shows that Poe was at this time displaying the qualities which form the distinctive marks of his later work. If it can be shown that his knowledge of German fiction, either in original or translation, had not yet begun, the point is of decided importance in establishing the true relation of German influence to his work in total.

The fact known as to the studies that Poe pursued at the university are related in the recollections of the first librarian of the institution, Mr. William Wertenbaker.

"He (Poe) entered the schools of Ancient and Modern Languages, attending the lectures in Latin, Greek, French, Spanish and Italian. I was myself a member of the last three classes, and can testify that he was tolerably regular in attendance, and a successful student, having obtained distinction in Latin and French."22

Had Poe attended the class in German, Mr. Wertenbaker could not have failed to know it for several reasons. The total number of students was small, 170 in all. There were only 90 men in the department of Modern Languages. To have been a student of German would have made Poe a marked man. Professor Gruener calls attention to the interest in German that was just then springing up. It was just this fact that would have made Poe's example conspicuous. Compare for a moment the conditions existing at Harvard at exactly the same period. Dr. $\mathrm{S}$. H. Goodnight of the University of Wisconsin has shown that German was practically unknown at Harvard until 1825, when Dr. Follen began his instruction in this language. ${ }^{23}$ Dr. A. P.

22. Harrison: Works of Edgar Allan Poe, Vol. 1, p. 45.

23. German Literature in American Magazines prior to 1846. By Scott Holland Goodnight, Bulletin of University of Wisconsin, No. 188, Philology and Literature Series, Vol. 4, No. 1. 
Peabody is quoted as saying of this event: "German had never been taught in college before, and it was with no little difficulty that a volunteer class of eight was found desirous, or at least zcilling, to avail themselves of his (Dr. Follen's) services. I was one of that class. We acere looked upon zoith very much the amasement with which a class in some obscure tribal dialect of the remotest Orient would now be regarded. . . . . . There were no German books in the bookstores. There were no attainable class books that could be used as readers. . . . . . The German Reader for beginners, compiled by our teacher, was furnished to the class in single sheets as it was needed, and was printed in Roman type, there being no German type in easy reach."

Conditions at the University of Virginia must have been practically similar when Professor Blaetterman began his work. Had Poe been among those to take up the new study, the fact would have been far more striking than his attendance in other classes, and could not have escaped some comment by his friends, Mr. Thos. Goode Tucker, Mr. Wm. Burwell, and Mr. Wm. Wertenbaker, who have left rather minute and detailed recollections of Poe at the university. ${ }^{24}$ Moreover, before these gentlemen prepared their recollections, it had become a well established literary opinion that Poe was somewhat affected by German. The first criticism of Poe's stories that appeared in the Southern Litcrary Messenger contains reference to supposed German influence, and this opinion was repeated in every further comment made by this magazine upor his stories. It is true that Poe disclaimed this influence, 25 but in view of this general literary opinion, it seems inconceivable that, if Poe had regularly studied German at the university, the men most closely associated with him should have never thought worthy of record what they should

24. For Mr. Tucker's account, see "Old Oddity Papers," University of Va. Magazine, Vol. XIX, pp. 376-381 and 426-445. "Edgar A. Poe and His College Contemporaries," by Hon. Wm. H. Burwell, editor of DeBow's Review, in the New Orleans Times-Democrat, 1844. Recollections of Poe, by Wm. Wertenbaker, contained in a paper by Prof. Jas. H. Farrison in the "Independent," Sept., 1900.

25. Preface to "The Tales of the Grotesque and Arabesque." 
naturally have regarded as the most significant fact in his entire university career.

Suppose we accept Professor Gruener's other supposition, that Poe studied German privately. This fact would undoubtedly have been known to his close and intimate friend, Mr. Thos. Goode Tucker. Theirs was no mere acquaintance, but a "warm, impulsive, genuine college friendship." 20 They were constantly together and "managed to spend a good portion of their time in the university library engaged in reading the histories of Lingard and Hume, while to them the whole field of English poetry from Chaucer to Scott was perfectly familiar, and it was one of their favorite pastimes to engage for hours in writing to each other those passages of particular beauty and striking thought that had especially attracted their attention." $2 \pi$ It is hardly possible that a friend of this character could have known nothing of time that Poe was giving to the mastery of a foreign language like German.

Again, Professor Gruener represents Poe's course as a light one for his talent, and maintains that he had abundant time for the study of German outside of class. If, however, we take the account of the facts just mentioned concerning the habits of the two friends, if we recall the fact that Poe gave much time to gaming and convivial pleasures, ${ }^{28}$ that he was in the habit of taking long rambles in the mountains, ${ }^{29}$ and if we add to all these the five regular courses that Poe is known to have followed, it seems difficult to agree with Professor Gruener in his conclusion as to Poe's time for private study of German.

Again, Poe's use of the university library should throw some light on the question of his interest in German at that time. Says Mr. Wertenbaker: "During the year 1826, there used to come into the library a young student (Poe) perhaps eighteen years of age in search of old French books, principally histories." 30 It is a matter of record that Poe did not procure from the library any book connected with either German language or literature. ${ }^{31}$

26. University of Va. Mag. Vol. XIX, p. 429.

27. University of Va. Mag. Vol. XIX, p. 379.

28. University of Va. Mag. Vol, XIX, p. 428.

29. University of Va. Mag. Vol. XIX, p. 433 .

30. University of Va. Mag. Vol. XIX, No. 1, p 45.

31. Harrison: Works of Edgar Allan Poe, Vol. 1, p. 47. 
The first catalogue of the library of the university was published in 1828.32 An examination of this shows that even then the library did not contain in original or translation any work of Hoffmann, Tieck, or other German romantic writers of fiction. There were, however, a number of books on German language which Poe would almost certainly have been led to borrow at some time had he been engaged in the private study of the language.

Dr. Palmer Cobb mentions several translations of German tales appearing in London and Edinburgh in 1826,33 among these stories by Hoffmann, Tieck, Fougue, Schiller, Langbein and Engel. From the conditions of the time, it is impossible to believe that Poe could have known of the appearance of these works at that time or could have procured them during his stay at the university. Except the translation of "Die Elixiere des Teufels," which appeared in Blackwood's Magazine in 1824, there does not seem to be any German fiction with which Poe can reasonably be believed to have been acquainted before he left the university in 1826 .

It must be admitted that the evidence that has been advanced to disprove Poe's interest in German at this time is entirely of a negative character, but owing to the peculiar character of Poe's special case, negative evidence is almost as convincing as positive proof.

To sum up the results of this very brief inquiry into the question of German influence on Poe, the conclusion seems warranted that Poe in 1826 was composing prose fiction exactly similar to his later work, both in subject and style; that his knowledge of the German language had not yet begun; and that with the possible exception of one story, he was as yet probably unacquainted with the work of Hoffmann, that his interest in Hoffmann was probably first aroused by Scott's article on Hoffmann in the Foreign Quarterly Review (July, 1827); that his later debt to Hoffmann consists in the suggestion of certain motives for perhaps four or five of his stories; that his adaptation of these motives-if he really procured them from Hoffmann-resulted

32. University of Va. Library.

33. Pages 15-18. 
in a product entirely new and distinctly different from anything Hoffmann had produced.

In conclusion, it may be noted that as far as any literary form may be justly regarded as an invention, the technique of the modern short story as a distinct literary type is to be credited chiefly to Poe. 


\section{CHAPTER III}

\section{The Tales of the Southern Magazines and Newspapers FROM 1834 TO 1860}

The present chapter is designed to present three topics; first, the general tendencies of the Southern magazine tales prior to the sixties; second, the work of William Gilmore Simms in the short story; and, lastly, the work of the humorous sketch writers of the far South.

A detailed discussion of all the short fiction contained in the magazines $^{1}$ that have been examined in the preparation of this treatise would be a somewhat profitless task. The stories in the Southern Literary Messenger of Richmond, Virginia, (18341864) may be regarded as representative of the general tendencies then prevailing in Southern fiction. As typical of the best work then being done in the Scuth in the several kinds of fiction, ${ }^{2}$ it may be safely male the basis for any general conclusion. Simms, notwithstanding his comparatively small output in the short story, appears to deserve separate treatment on account of his position as the most prominent writer of fiction in the South at this period. The group of humorous sketch writers, including Judge A. B. Longstreet, Joseph G. Baldwin, Wm. Tappan Thompson, Johnson Hooper, and George W. Harris, constitute a class to themselves. Although much of their humor has lost its appeal to the present age, their work constitutes a very original and characteristic product of a certain phase of Southern life, and forms a decideclly important element in the growth of the Southern short story.

The short fiction contained in the issues of the Southern Literary Messenger falls roughly into three general groups: tales founded upon historical incidents; stories of contemporary social life; narratives of adventure taken chiefly from the life of the frontier. Added to these, the translation of stories from foreign literature, principally the German, became very common in the forties.

1. See list of magazines, appended to the text, p. 99.

2. Poe is excluded from all remarks in this chapter. 
The tales founded upon historical incidents range from the events of the American and the French Revolutions back to Medixval times, and even to the clays of the Roman Empire. None of these narratives rises above the level of mediocrity. We search in vain for any very vivid character portrayal, and find all these stories trammeled by lack of condensation and focus, by conventionality of plot, and by the absence of satisfying climax. If the tale is one of remote times, the style usually tends to become overpowering in its dignity and solemnity. The effort for effect is too apparent and what is intended to be tragic becomes too often only melodramatic.

In the tales of social life, the faults are those common to the magazine story in general in the first half of the last century. They range from the weakly sentimental to the unduly sensational. The task of being earnest and strong and at the same time simple and natural seemed too much for the average magazine contributor of that time. With the edifying purpose of depicting the evils of social life, the authors of the clay found their favorite material in incidents of unhappy love, unfortunate marriages, the betrayal of innocent confidence and affection, and the hatred and revenge of rivals. A handsome and dashing young man wins the affection of a lovely, confiding girl. Circumstances separate them, and the unfaithful hero woes and weds another. The heroine hears of the dastardly act, falls in a dramatic faint and thence into a rapid and melancholy decline. This type, with interesting variations, is only too common.

It is true that here and there a story of healthy sentiment and genuine feeling is found among the mass of uninteresting sentimental narratives, yet it remains true that the overabundance of the sentimental element was one of the most common faults. A few specimen titles will indicate the type.

"The Blighted One," (May, 1839); "Naked Hearts, or Confidential Correspondence," (Apr., 1841) ; "The Victim of Love," (July, 1839); "The Perils of Passion," (Jan., 1838); "The Curse," (May, 1837); "Love at the Shrines," (Aug., 1837); "Love and Constancy," (Jan., 1836) ; "The Reclaimed," (Aug., 1835); "The Doom," (Jan, 1835); "The Palsied Heart," (May, 1842); "The Elopement," (Nov., 1842); "Female Revenge," (Mar., 1843) ; "The Fatal Effects of Insincerity," (Oct., 1843); 
THE TALES OF SOUTHERN MAGAZINES FROM 1834 TO 186027

"The Temptation and Triumph," (Sept., 1845); "Wilful Love," (Feb., 1846); "Woe and Weal," (Aug., 1847).

The extreme of melancholy sentiment is reached in "Henry Norman and Mary Neville," by J. C. McCabe of Petersburg, Va., in the July number of the Messenger for 1841. The hero of the tale is, of course, of the eminently correct romantic type, of "tall and manly form" and "lofty brow" with "dark expressive eye" and "firm but musical voice"; the heroine the usual "lovely drooping flower." Disease has laid hold of her frail form, and at the opening of the story the melancholy information is conveyed to the reader that she is "destined soon to lie down and make her cold bed amid the green leaves of the church yard." In view of this impending fate, the marriage is hastened. At the ceremony, the bride dramatically expires, and the wretched bridegroom disappears; no one knows whither. Years pass by, and one Sunday morning a stranger, a gray haired missionary, preaches in the village church. That night, a night "eloquent with stars, when the winds whispered among the drooping flowers, and seemeil hymning a sad sweet roundelay amid the foliage of the trees," Henry Norman was found in the little clurchyard lying across the grave of Mary Neville. In the agony of his grief, he had broken a blood vessel, and after a few eloquent words he was dead. As if the gloom of the narrative were not sufficiently intense, the tale is filled with sombre reflections of the author interspersed with passages of melancholy verse.

The sensational plot is well exemplified in "Female Revenge" signed E. M. D. C., Occoquon, Va. A girl is deceived by her lover. She thereupon invites him and her rival, who is also her best friend to a meal, and there poisons them. Then, taking up the role of a poisoner of young men, she continues her destructive work. When discovered she plunges a dagger into her bosom.

The tendency to sermonize through stories of social life is shown in a series of tales issued in Russell's Magazine of Charleston, S. C., in 1857-'58, by Mrs. Sue Petigru King Bowen. The series, under the general title "Crimes Which the Law Does Not Reach," consists of "Gossip," (Oct., 1857); "The Marriage of Persuasion," (Nov., 1857); "The Male Flirt," (Dec., 1857), "The Best of Friends," (Jan., 1858). 
In addition to the faults in material that have been mentioned, the magazine tales of the period also show weakness in construction and style. There is evidence at times of extremely amateurish work. The lack of constructive skill may be illustrated by "The Elopement" (So. Lit. Mess., Nov., 1842). At the crisis in the story, when a boat has been sent out into the river to rescue a young man and young woman about to sink, the author stops in the midst of the inciclent to explain how the rescuers happen to be present. On the side of style a leading fault, particularly in the tales clealing with society life, is the frequent use of lavish sentimental descriptions. "Florence Courtland. By a Lady of Virginia." (So. Lit. Mess., July, 1842) begins as follows :

"Night, the genmed and beautiful night, undimmed by fleecy cloud or envious mist, was holding revel in the sky. In sparkling group, or silvery galaxy, each star was turning its golden eye toward the East, and clustering together upon the blue concave shone forth the daughters of the ocean nymphs, the glittering Pleiades,"-and so on for a paragraph of five hundred words, and all to introduce a very simple love story.

In justice to the writers who occasionally contributed a well written and interesting story to the pages of such magazines as the Messenger, it is proper to note that the faults here set forth were not universal. It must be observed, however, the tales of the Southern magazines at this period give little evidence that the technique of Poe had been learned. The narratives, even when well expressed and totally free from the faults that have just been discussed, still remain tales of the older type, and do not assume the structural character of the typical nineteenth century short story.

Many female writers were contributing to magazines in other sections of the South. Caroline H. Gilman (1794-1888) edited in Charleston, S. C., The Southern Rose Bud, (1833-1835) which she changed into The Southern Rose, (1836-39). To this she contributed stories for children and also issued two volumes of such writings. ${ }^{3}$ Maria G. McIntosh (1803-1878), of Georgia, published in 1849 "Evenings at Donalson Manor," a

3. Johnson: Southern Fiction Prior to 1860, p. 31. 
THE TALES OF SOUTHERN MAGAZINES FROM 1834 to 186029

collection of stories from magazines. ${ }^{4}$ Annie R. Bount, of Augusta, $\mathrm{Ga}$. received a medal valued at $\$ 100$ for a short story called "The Sisters," published in the Neruberne Gavette, 1859.5 Mrs. N. W. Hentz (Caroline Lee Whiting, 1800-1856), although born in Massachtsetts, became identified with the South by her long residence in Alabama and gained sufficient insight into Southern spirit and views to produce faithful pictures of her section. She was a prolific writer and issued several volumes of short stories: "Aunt Patty's Scrap Bag," (1846); "Wild Jack; or the Stolen Child, and Other Stories," (1853); "The Victims of Excitement," including other stories, (1853); "Joys and Sorrows of Anerican Life," (1856). ${ }^{\circ}$ Among other writers of short stories may be mentioned Mrs. Bennet (Martha Haines Butt, of Norfolk, Va.), who published "Leisure Moments," (1859), a collection of tales and sketches; ${ }^{7}$ Mary Elizabeth Morange, born at Oakwood, S. C., 1815, who contributed short stories to the Augusta Mirror. ${ }^{8}$

\section{WILLIAM GILMORE SIMMS}

Simms has been described by Professor Trent as the most versatile man of letters the South has produced. From so prolific a writer of fiction some contribution to the department of the short story might naturally be expected. His short stories belong almost entirely to the early period of his work. Soon after the publication of "Martin Faber," his first novel (1833), he issued "The Book of My Lady," a collection of short stories which had previously appeared in magazines. In 1845 he made another collection of short stories in the volume entitled "The Wigwam and the Cabin." These tales, many of which had been issued in annuals, constitute the best work of Simms in this branch of fiction. The author says of these stories:

"The material employed will be found to illustrate, in large degree, the border history of the South. I can speak with con-

4. Davidson: Living Writers of the South, p. 363.

5. Forrest: Women of the South, p. 416.

6. Johnson: So. Fict. Prior to 1860, pp. 34-35.

7. Tardy: Southland Writers, p. 806.

8. Hart: Female Prose Writers of America, p. 453. 
fidence of the general truthftulness of the treatment. The life of the planter, the squatter, the Indian, the negro, the bold and hardy pioneer, the vigorous yeoman-these are the subjects. In their delineation, I have mcstly drawn from living portraits and in frequent instances from actual scenes and circumstances within the memories of men."

The tales included in the volume are: "Grayling, or Murder Will Out;" "The Two Camps, a Legend of the Old North. State;" "The Last Wager, or the Gamesters of Mississippi ;" "The Armchair of Tustenugge, a Trudition of the Catawba;" "The Snake of the Cabin;" "Oakatibbe, or the Choctaw Samson;" and "Jocasse, a Cherokee Legend." Decidedly the best of these is the first, "Murder Will Out." When it appeared in the annual, "The Gift," published by Carey and Hart in 1842, it attracted enough attention to be highly commended by the London E.taminer.

Poe, in his criticism of these tales in the Broadicuay Journal for Oct. 4, 1845, says of the story, "Murder Will Out:" "We have no hesitation in calling it the best ghost story we ever read. It is full of the richest and most vigorous innagination-it is forcibly conceived-and detailed throughout with a degree of artistic skill which has no parallel among American story tellers since the epoch of Brockclen Brown."

As Professor Trent remarks, this praise seems slightly extravagant; the story is hardly written as Poe or Hawthorne would have handled the same material. ${ }^{10}$ The setting and tone of the narrative are not perfectly executed, and the solution of the mystery is no nearly obvious as to require a very simple process of analysis.

It is interesting to note that in point of pure style Simms's short stories are in some respects superior to his longer narratives. Professor Trent says of his early stories: "Some of these show that Simms was master of a prose style, which, if not charming, might nevertheless with a little pains have been made distinctly graceful. Unfortunately as years went by and the temptation to hurried work became less easy to resist, his style lost these early traces of pleasing quality, and was never more

9. Introduction to "The Wigwam and the Cabin."

10. Trent: Southern Writers, p. 150. 
than a serviceable style, with some strength, but with a constant tendency to become slipshod."11

This criticism suggests plainly the causes of Simms's deficiency as a writer of short stories. Although he was fluent, he was not, in the highest sense, artistic, and there is no form in which execution counts for so much as in the short story. His constructive ability showed itself chiefly in the execution of a large plan, and not in the skilful manipulation of details. It is not an entirely sound literary law that the writer of novels cannot be successful in the short story. Still, it will always be found that the novelist who succeeds with the short story is conspictrous for artistic finish, attention to minute details, and for great directness and economy of expression. These qualities Simms did not display. The interest aroused by his novels is chiefly due to the cumliative force of many incidents leading up to a tragic situation; his thrilling effects are all secured by rather complex arrangements and lengthy suspense. As tales of the border life, Simms's short stories are the best of their type of that period, but they show no new skill in handling, no new grasp of structure. They are tales built on the method of the older schools of fiction, ${ }^{12}$ and make no advance toward the method of the modern short story.

\section{THE HUMOROUS SKETCH WRITERS}

During the thirties and forties the far South became the field of much humorous writing in sketches and short narratives. The life of the small farmer class in middle Georgia and the rapid development of Alabama and Mississippi through speculation furnished many humorous situations, sharp contrasts of character, and abundant opportunity for the display of shrewdness, racy wit and rich humor of a wholesome, rollicking sort. In such a society as then existed in the far South and Southwest there was abundant work for the lawyer. The men of this profession, especially when they happened to be men of close observation and keen sense of humor, could not fail to gather abundant material suitable for sketches and short stories.

The life of the country districts of middle Georgia, for ex-

11. Trent: Southern Writers, p. 82.

12. Simms's master was Scott. 
ample, differed materially from that of Virginia, Maryland or even the Carolinas. Plantations were smaller, life was less conventional and exclusive. The population was more homogeneous and in some respect more provincial and pronounced in its peculiarities. ${ }^{13}$ Life abounded in quaint and picturesque features. The popular customs and traits, the religious views and habits of the people, all afforded excellent opportunity for picturesque and amusing portrayal.

Most prominent among those who were led to delineate the humorous side of this interesting life was Augustus Baldwin Longstreet, ${ }^{14}$ who was born in Augusta, Ga., in 1790. After serving a term in the legislature of his state, he was, in 1822, appointed a Juclge of the Supreme Court of Georgia. The year 1838 marked a turning point in his life. The death of a relative gave a serious turn to his thoughts, and uncler the influence of deepening religious conviction, he clecided to abandon law and enter the ministry. He became pastor of a church in Augusta and served effectively in this capacity. In 1839 he became president of Centenary College, Louisiana, and subsequently held similar offices in the South Carolina College and the University of Mississippi.

Longstreet during his experience as a lawyer had excellent opportunity for studying the peculiar people among whom he lived. During his editorship of The Augusta Sentinel, he issued from time to time in its pages sketches signeil "Hall" and "Baldwin." In 1835 these sketches were collected in a volume published at the Sentincl press in Augusta, under the title "Georgia Scenes." The book became widely known and a second edition was published by Harpers in 1840 , but the author refused to revise it. Having entered the ministry, he felt that the rather gross, rolicksome humor of the scenes and the occasional profanity were unbecoming in one of his profession, and when the third eclition was issued in 1867 , he refused to have anything to do with the work.

The style of the book is racy, and the incilents those of actual life among the "Crackers" of middle Georgia. The humor

13. Baskervill: Southern Writers, pp. 70-78.

14. On Longstreet see: Appl., Vol. IV, p. 17; Trent, p. 121; Holladay, p. 161; Rutherford, p. 153. 
THE TAIES OF SOUTHERN MAGAZINES FROM 1834 TO 186033

is partly in the situations and partly in the touches which the author gives in the telling There is a vigorous, hearty spirit in the tales, revealing the vitality of the life from which they sprang. The humor is often broad, the language is sometimes coarse, the characters unrefined, but simple and genuine. Longstreet has presented in this work certain phases of rustic life which would have been lost to the world had they not been preserved in his laughable sketches. The rural population was drawn together by numerous causes; such as the barbecue, stump speaking, the military muster, and the meetings of county and circuit courts. Crowds assembled on such occasions, and country pastimes were then rife. Amid the horse swapping and other business at such public getherings, drinking and fighting were freely indulged in. Besides the gatherings just mentioned, the meetings of neighbors at corn-shuckings, log-rollings, houseraisings, and wheat-threshings gave a social character to the work of the farm, and incidentally led to many humorous situations. It is this type of free, rollicking life that is pictured in "Georgia Scenes." 15

In the preface of the first edition, Longstreet says of these scenes. "They consist of nothing more than fanciful combinations of real incidents and characters; and throwing into those scenes, which would otherwise be dull and insipid, some personal incident or adventure of my own, real or imaginary, as it would best suit my purpose; usually, real, happening at different times and under different circumstances from those which are here represented. I have not always this liberty. Some of the scenes are as literally true as the frailties of memory will allow them to be."

In the eighteen sketches contained in the volume, the descriptions are always given in vigorous style and show close observation and a fine sense of humor. In "The Dance" we are told how Rhoda Noble "swam through the reel like a cork on wavy waters, always giving two or three little perch bite dribbles as she rose from coupee." In "The Horse Swap," a character picture is given of "Cracker" sharp dealing when the traders, by their skill-

15. On Georgia life at this period, see Link, Vol. II, pp. 479, et seq. 
ful exchanges, both succeed in cheating each other. The sketch of Ned Brace in "The Character of a Native Georgian," gives an excellent picture of the born practical joker. Judge Longstreet feels it his duty to apologize in a footnote for Ned's propensity for swearing. Ned destroys the solemnity of a church service by his discordant singing, and on one occasion causes a funeral procession to become convulsed with laughter. In the sketch entitled "The Debating Society" the reacler is treated to an illuminating discussion of the question "Whether at public elections the votes of the faction should predominate by internal suggestion or by the bias of jurisprudence." "The Gander Pulling" is one of the most spirited of these sketches. The account of how the mare, "Sally Spitfire," ran away with a gradually increasing escort of domestic animals is no less amusing than the description of a "Gridiron's" running "as the result of pure philosophic deduction."

Two of the sketches deserve special note, one on account of its probable influence on another sketch, and the second as being directly borrowed for a modern novel. If the sketch called "The Song" is compared very closely with Dr. George W. Bagby's famous sketch, "Jud Brownin's Account of Rubenstein's Playing," it seems hard to resist the conclusion that Dr. Bagby was strongly influenced in the use of some of his ludicrous expressions by Judge Longstreet's account of how Miss Aurelia Thedosia Crump played the piano. From Dr. Bagby's natural bent we may reasonably infer that he was well acquainted with Longstreet's work. If he had ever read this particular sketch, he could not well have written his own without being conscious of the points of similarity.

The other sketch referred to, which has given rise apparently to a direct case of plagiarism, is "The Militia Company Drill." The Bookman for February, 1906, called attention to the fact that a passage from this sketch had evidently been inserted by Thomas Fardy in his novel "The Trumpet Major."10 A comparison of the passages given below makes it clear that the verbal similarity is too striking to be explaineil as entirely acciclental.

16. "The Militia Company Drill" was in the opinion of Prof. Trent written by a friend of Judge Longstreet, Oliver $H$. Prince, (1787-1837) who represented Georgia for a short term in the United 
THE TALES OF SOUTHERN MAGAZINES FROM 1834 TO 186035

These passages' are not continuous but are taken from different pages as indicated by the numbers attached to each paragraph.

LONGSTREET: "THE MILITIA COMPANY DRILL"

"But as every man was anxious to see how the rest stood, those on the wings pressed forward for that purpose, till the whole line assumed nearly the form of a crescent. (p. 197)

" "Why, look at 'em," "said the captain; "why, gentlemen, you are all crooking in at both ends, so that you will get on to me by and by! come gentlemen, dress, dress!" (197-198)

This was accordingly done; but impelled by the same motives as before, they soon resumed their former figure, and so they were permitted to remain. (198)

" " - and I want you, gentlemen, if please, to pay particular attention to the word of command, just exactly as I give it to you. I hope you will have a little patience, gentlemen, if you please; and if I should be agoing wrong, I will be much obliged for the best, and I hope you will excuse me, if you please. (198)

"'Tention the whole! Please to observe, gentlemen, that at the word 'fire' you must fire; that is, if any of your guns are loaden'd, you must not shoot in yearnest, but only make pretence like; and you, gentlemen, fellow soldiers, who's armed with nothing but sticks, riding switches and cornstalks, needn't go through the firings, but stand as you are, and keep yourselves to yourselves. (200)

" 'Handsomely done! and all together, too, except that onehalf of you were a leetle too soon, and the other half a leetle too late. (201)

"Tention the whole! To the left-left, no-right-that is, the left-I mean the right, left wheel, march!'

"In this way he was strictly obeyed; some wheeling to the right, some to the left, and some to the right-left, or both ways.

"'Stop! halt! Let us try again! I could not just then tell

States Senate. See Trent, p. 122. According to a note appended by Longstreet to "The Militia Company Drill" the story had first been published by his friend about twenty years before the date of "Georgia Scenes." 
my right hand from my left! You must excuse me, if you please; experience makes perfect, as the saying is. Long as I have served, I find something to learn every day; but alls one for that-. (205)

hardy: "the trumpet major" (chap. ximit)

"Every man was anxious to see how the rest stood, those at the end of the line pressed forward for that purpose, till the line assumed the form of a bow.

"'Look at ye now! Why, you are all crooking in. Dress, dress!'

"They dressed forthwith; but impelled by the same motive they soon resumed their former figure, and so they were despairingly permitted to remain. (208)

"'Now, I hope you'll have patience,' said the sergeant, as he stood in the centre of the arc, 'and pay particular attention to the word of command, just exactly as I give it out to ye; and if I should go wrong, I shall be much obliged to any gentleman who'll put me right again, for I have only been in the army three weeks myself, and we are liable to mistakes.'

" "Please, what must we do that haven't got no fire-locks?" said the lower end of the line in a helpless voice.

"Now, was ever such a question! Why, you must do nothing at all, but think, how you'd poise 'em if you had 'em. The middle men that are armed with hurdle-sticks and cabbagestumps, just to make believe, must, of course, use 'em as if they were the real thing. Now then, cock fawlocks! Present! Fire! (Not shoot in earnest, you know. Pretend to, I mean, and at the same time throw your imagination into the field of battle.) Very good-very good indeed; except that some of you were a little too soon, and the rest a little too late. (209)

"'Tention! To the right-left wheel. I mean-no, no-right wheel. Mar-r-r-rch!'

"Some wheeled to the right and some to the left, and some obliging men, including Cripplestraw, tried to wheel both ways.

"'Stop, stop; try again. 'Cruits and comrades, unfortunately 
THE TALES OF SOUTHERN MAGAZINES FROM 1834 TO 186037

when I'm in a hurry I can never remember my right hand from my left, and never could as a boy. (210)

"You must excuse me, please. Practice makes perfect, as the saying is; and mucl as I have learnt since I 'listed, we always find something new Now, then, right wheel! march! halt!-, " (211)

Although Longstreet's slietches have not the development of plot and denouement essential to the true short story, they have been influertial in the development of this type of narrative in the South. Longstreet was in reality a pioneer in the field of realistic presentation of humorous local types and peculiar phases of society. In this respect he is the literary forerunner of Bret Harte, Mark Twain and the great host of writers who have enricher the humorous literature of America by a faithful portrayal of local peculiarities. Longstreet's immediate successor in Georgia was Richard Malcolm Jolnnston, who will be considered in the later clevelopment of the "Cracker" story.

The contemporary estimate of Longstreet's book cannot be given better than in the words of the grave and serious Poe. In his criticism of "Georgia Scenes" he says:

"Seriously, if this book were printed in England, it would make the fortune of the author..... Seldom-perhaps never in our lives-have we laughed as immoderately over any book as over the one now before us. . . . The author is imbued with a spirit of the truest humor and enclowed, moreover, with an exquisitely discriminative understanding of character in general and Southern character in particular."17

\section{WILLIAM TAPPAN THIOMPSON}

A name associated with Judge Longstreet's among the Georgia humorists is that of William Tappan Thompson, ${ }^{18}$ a newspaper editor remembered chiefly as the writer of the amusing dialect sketches, "Major Jones's Courtship;" "Major Jones's Chronicles of Pineville," and "Major Jones's Sketches of Travel." The

17. So. Lit. Mess., Feb., 1836.

18. Trent, p. 252; Holladay, p. 164; Rutherford, p. 372. 
author, of Virginia descent, on his father's side, was born in Ravenna, Ohio, in 1812, but moved to Georgia at the age of twenty-three. He soon began to assist Judge Longstreet in editing the States Rights Sentinel in Augusta. In 1836, he established in Augusta the Mirror, the first purely literary paper attempted in the state. From 1840 to 1845 he edited the Miscellany in Madison, Georgia. In this paper appeared his "Major Jones's Letters," which in 1840 were published in Philadelphia as "Major Jones's Courtship." After an interval of three years came "Major Jones's Chronicles of Pineville," and in 1848 "Major Jones's Sketches of Travel."

It was probably Thompson's association with Judge Longstreet which gave the first impetus to his humorous talent. Unlike Longstreet, however, he employs the "Cracker" dialect, and gains much of his humorous effect by relating the incidents from the standpoint of his honest, simple-minded and luckless hero, Major Jones. In the sketches of the first series, the ardent major, in his courtship of Miss Mary Stallins, is made the victim of many ludicrous mishaps. Yet in spite of his awkward accidents, due to bashfulness, clumsiness, and excess of ardor, his pure devotion finally triumphs over his rival and all other obstacles.

Althougl Thompson presents the scenes in the form of letters, his sketches, in some instances, attain more definitely the form of a story than do those of Longstreet. For example, in the famous sketch in which the Major presents himself to Miss Mary Jane as a Christmas gift, hung in a huge meal sack at her front door, there is a clear clevelopment of plot and a striking and well prepared denouement. Other episodes, such as the Major's unlucky fall from the tree into the water, are stories rather than sketches, since the narrative purpose predominates over the descriptive.

Apart, then, from differences of subject, the sketches of Thompson may be said to differ from those of Longstreet in the use of dialect, in the more distinct development of character and

plot, and the predominance of the narrative over the descriptive element.

JOHNSON JONES HOOPER

As Longstreet and Thompson give pictures of life in Georgia, 
Johnson Hooper ${ }^{10}$ describes in his sketches some peculiar phases of Alabama life. His "History of the Life and Adventures of Capt. Simon Suggs of the Tallapoosa Volunteers" delineates the character of a slarp, vulgar and unprincipled adventurer. The Captain's vein of humor, his sunny light-hearted manner of perpetrating fraud, and the genuinely amusing situations that arise in the course of the narrative force the reader to laugh in spite of the utterly reprobate character of the hero. The book was appreciated and praised by Thackeray. ${ }^{20}$

In "Oddities in Southern Life and Character" Col. Watterson says: "It has often been stated that Simon was taken from a real personage, by the name of Bird, and the story goes that this individual did on a certain occasion call Mr. Hooper to account for making too free with his lineaments and practices. It may be so; but the likelihood is that the author in this instance followed the example of other writers of fiction and drew his hero from many scraps and odd ends of individual character to be encountered at times in the country towns and upon the rural highways of the South."21

Johnson Hooper was a native of North Carolina, but had moved to Alabama to take up the practice of law. About 1853, he established the Mail, a prominent Whig paper, in Montgomery. Later he acted as secretary of the provisional Confederate Congress at Montgomery and then at Richmond, and later still as private secretary to Leroy $P$. Walker, the Confederate Secretary of War. Mr. Hooper was connected with various Alabama papers. In these his humorous sketches appeared. Part of "Simon Suggs" was probably issued in the East Alabamian. The

19. Appl., Vol. III, p. 252; Trent, p. 270; Holladay, p. 166; Rutherford, p. 376.

20. This statement is made on the authority of Trent's "Southern Writers," p. 271. The author wrote to Prof. Trent to ascertain his authority for this statement. Prof. Trent replied that his notes for this volume had been destroyed but that the accuracy of the remark could be relied on as he had been scrupulously careful in taking notes for this work and he was confident that he had quoted this remark from a thoroughly reliable contemporary account of some of Thackeray's conversations in America.

21. Page 59. 
book was ptiblished in Philadlelphia in 1845 and a second edition in 1881 .

The full title of the work was "Some Adventures of Capt. Simon Suggs, late of the Tallapoosa Volunteers; together with 'Taking the Census' and other Alabama Sketches. By a Country Editor." In 1851, he published "Widow Rugby's Husband and Other Tales of Alabama." This is not equal in merit to his first work.

The separate episocles of "Simon Suggs" are practically complete narratives, and may be regarded as stories rather than sketches. The Captain's most outrageous frauds are often practiced under the guise of piety. The story of lis conversion and his appropriation of the collection raised at the meeting is one of the most striking in the book.

\section{HENRY JUNIUS NOTT}

The type of humor found in "Simon Suggs" had been illustrated at a much earlier clate in the work of a South Carolina writer, Henry Junius Nott. "Novellettes of a Traveler" is described by Dr. George A. Wauchope of the University of South Carolina as "a collection of grotesque and whimsical short stories, which are all bubbling over with irony and a rough farcial humor." Thomas Singularity, the hero of these stories, is according to the same writer, "a sharpes 'deadbeat' and unscrupulous rascala lineal descendent of the rouges of the early picaresque romances."22

GEORGE W. HARRIS

Life in Tennessee is pictured in the work of another humorist, George W. Harris. ${ }^{23}$ His "Sut Lovingood's Yarns" are humorous tales of mountain life told in somewhat vulgar style. The language is coarse, the humor broad and unrefined. Sut is a careless, fun-loving, whiskcy-clrinking mountaineer of the rudest type. The yarns usually set forth some comical situation produced by Sut's inborn genius for the practical joke. Occasionally he is himself the victim, but his retaliation usually vanquishes

22. Wauchope: "The Writers of South Carolina," p. 59. For an account of the life of Henry Junius Nott, sec the same work, p. 303.

23. Appl., Vol. III, p. 91. 
THE TALES OF SOUTHERN MAGAZINES FROM 1834 TO 186041

completely his adversary. Typical country gatherings, such as the quilting, the dance, the wedding, the funeral, the religious meeting, are made the occasion for humorous mishaps of the most boisterous type.

There is no genuine portrayal of character in these tales and no hint of finer feeling underlying the rough exterior of this mountain life. In a word, there is nothing that suggests the interest or pathos of "Craddock's" pictures of the Tennessee mountain of a later time. John Basil Lamar's description of the North Carolina mountaineer in "The Blacksmith of the Mountain Pass" is suggestive of some fine and sturdy qualities in his pugnacious hero. Sut Lovingood is the mountaineer only in burlesque.

Harris's tales are not clearly localized. Knoxville is made the scene of one. Another is located in Lynchburg, Virginia, which is characteristically described as a town built "an sot on hits aidge to dry" but never turned down again.

\section{JOSEPH BALDWIN}

We have spoken of the period of speculation and clevelopment in Alabama and Mississippi beginning about 1835. The picture of conditions in this section is given in Judge Joseph Baldwin's volume of sketches "Flush Times in Alabama and Mississippi."24 Professor Trent has pronounced this the best book of humorous sketches written in the ante-bellum South. Professor Trent, however, makes it clear that Baldwin's book is superior in literary quality, but not in pure humor, to the work of such writers as Longstreet, Thompson and Hooper.

Baldwin was born near Winchester, Virginia, in 1815. His reason for selecting the Southwest as the field for his law practice is given in the chapter entitled "Bench and Bar," where he describes in third person the commencement of his own career as follows:

"To the South West he started, because magnificent accounts came from that sunny land of the most cheering prospects of fussing, quarreling, murdering, violation of contracts, and the whole catalogue of crimen falsi-in fine, of a flush tide of litiga-

24. Appl., Vol. 1, p. 149; Trent, p. 266; Holladay, p. 255; Rutherford, p. 304 . 
tion in all its departments, civil and criminal. It was extolled as a legal Utopia, peopled by a race of eager litigants, only waiting for lawyers to come on and divide out to them the shells of a bountiful system of squabbling; a California of law, whose surface strife only indicated the vast placers of legal dispute waiting in untold profusion the presence of a few craftsmen to bring out the crude suits to some forum, or into chancery for trial or essay."

Most of the chapters in Baldwin's work are pure sketches. Here and there an anecdote of legal experience assumes the form of a distinct story. Specimens of this are seen in "The Earthquake Story" in the chapter on "Cave Burton, Esq., of Kentucky," "An Affair of Honor," and "Squire A and the Fritters."

Judge Baldwin is at his best in personal descriptions. It would be difficult to find a finer piece of ironic humor than his description of the character of "Ovid Bolus" in the first chapter of the work. After mentioning the difficulty he has experienced in assigning to Bolus his leading vice, he continues thus:

"I therefore take the responsibility of saying, after due reflection, that in my opinion Bolus's reputation stood higher for lying than for anything else; and in thus assigning prominence to this poetic property, I do it without any desire to derogate from the other brilliant characteristics belonging to the same general category which have drawn the wondering notice of the world.

"Some men are liars from interest; not because they have no regard for the truth, but because they have less regard for it than gain; some are liars from vanity, because they would rather be well thought of by others than have reason to think well of themselves; some are liars from a sort of necessity, which overbears by weight of temptation the sense of virtue; some are enticed away by the allurements of pleasure, or seduced by evil example and education. Bolus was none of these: he belonged to a higher department of the fine arts, and to a higher class of professors of this sort of Belles-Lettres. Bolus was a natural liar, just as some horses are natural pacers and some dogs natural setters. What he did in that walk was from the irresistible promptings of instinct and a disinterested love of art. His genius and his performances were free from the vulgar alloy of interest and temptation. Accordingly, he did not labor a lie; he lied with 
a relish; he lied with a coming appetite, growing with what it fed on; he lied with the delight of invention and charm of fictitious narrative. It is true that he applied his art to the practical purposes of life, but insofar did he glory the more in it; just as an ingenious machinist rejoices that his invention, while it has honored science, has also supplied a conmon want.

"Bolus's genius for lying was encyclopoediacal; it was what German criticism calls many-sided. It embraced all subjects without distinction or partiality. It was equally good upon all 'from grave to gay, from lively to severe.'

"Bolus's lying came from greatness of soul and from his comprehensiveness of mind. The truth was too small for him. Fact was too dry and commonplace for the fervor of his genius. Besides, great as was his memory-for he ever remembered the outlines of his chief lies-his invention was still larger. $\mathrm{He}$ had great contempt for history and historians. He thought them tame and timid cobblers; mere tinkers on other people's wares. ...... His experiments upon credulity, like charity, began at home. He had long torn down the partition wall between his imagination and his memory. All ideas were facts to him."

The "Flush Times" sketches were first issued in the Southern Literary Messenger, beginning in July, 1852, and with the exception of a few numbers extending to October, 1853. In the November number of 1853 appeared one division of "California Flush Times." Baldwin, after having attained considerable eminence as a lawyer in Alabama, had moved to California, where he was made a Judge of the Supreme Court in 1857, and in 1863 Chief Justice of the state. He died in San Francisco in the following year.

\section{OTHER HUMOROUS WRITERS}

The writers who have been noted in connection with the sketch and short tale in the far South were only the more striking among a large group who were doing similar work. In W. E. Burton's "Cyclopœedia of Wit and Humor" (1858) we find, along with stories of Longstreet, Thompson, Hooper, Simms and Kennedy, similar writings by John Basil Lamar, Hamilton $C$. Jones, T. A. Burke, T. B. Thorpe, ${ }^{25}$ and others.

25. On Thorpe, see Appl., Vol. VII, p. 105. 
One of the most prominent volumes of Southern humor was "Polly Peablossom's Wedding," dedicated to Johnson Hooper, and published in 1851. The initial story, from which the volume took its name, was written by John Basil Lamar, of Macon, Georgia. Hooper wrote one story for this volume, and Thompson two. Other writers represented were R. M. Charlton, ${ }^{28}$ W. C. Richards, W. T. Lane, and T. A. Burke. Some of the selections of this volume were taken from such papers as the New Orleans Picayune and Delta and the St. Louis Reveillc.

Many of the sketches and stories in Burton's "Cyclopcedia of Wit and Humor" had previously appeared in the New York Spirit of the Times. Among these may be mentioned Hamilton Jones's "Cousin Sally Dillard," a North Carolina sketch, "Jones's Tight," “A Quarter Race ir. Kentucky." Longstreet, Thompson, Hooper, Harris and Charlton were also contributors. ${ }^{27} \mathrm{Wm}$. T. Porter, the editor of the Spirit of the Times, macle several collections of sketches. One of these was embodied in Col. Thorpe's "Scenes in Arkansas," (1858). Thomas B. Thorpe, from whom this volume received its name, followed Porter as editor of the Spirit of the Times. Before this time, Thorpe had written humorous stories for papers in Louisiana. Hooper's "Simon Suggs" had appeared in this paper, also, before being issued in book form in 1845. It began in the issue for January 11th, 1844, and continued through several numbers. In the number for August 2nd, 1845, Thorpe calls attention to the fact that "Simon Suggs" along with its humorous and common-place incidents, contains some episodes showing pathos and decided literary merit. $\mathrm{He}$ compares the story of Litka and her lover with one of Addison's tales in the Spectator, "The Story of Inkla,"and shows that Hooper was capable of decided excellence of style.

The humorous sketches and stories that have just been noted were the occasional work of men, either engaged in business or professional life, or belonging to the planter class, who had no thought of literature as a profession, but who threw off, at random moments, these brief skits for newspaper publication. John B. Lamar has been mentioned as the author of "Polly Peablossom's

26. On Charlton, see Appl., Vol. 1, p. 583.

27. See the contribution of each in chronological list of stories, p. 1.01 . 
Weddling." I-amar was a fine type of the Southern planter, bold, noble-spirited and generous, possessing, besides, broad literary culture. He published many stories in papers, under the title of "Humorous Yarns." One of the most striking of his stories was "The Blacksmith of the Mountain Pass." To this a special interest belongs. The story was sufficiently striking to attract the attention of Dickens while on his American tour, and from it he constructed his story "Col. Quaggs' Conversion" which he published in Household Words, on his return to England. ${ }^{28}$

This brief examination of the Southern sketch writers of the ante-bellum period has shown that from 1835 to 1860 there was considerable literary activity in a field closely allied to the short story, and that this resulted actually in the production of many short stories of a simple type, usually humorous in style. The writers had protrayed a society highly picturesque in many of its features, and abounding in oddities of character and humorous situations. Their humor, while broad, was rarely gross and unrefined. Their treatment of life was at all times entirely human and wholesome. Throughout their portrayal of the ludicrous and absurd they displayed close observation, keen discernment of character, and a decided gift for ironic humor. Had the literary life of the South continued an unbroken development, their influence might have been more decidedly felt and their efforts, in spite of their simplicity, and lack of polish, might have speedily led the way to more finished work of a similar type. As it is, their influence can be traced in the writers who took up the literary life of this region where it had been broken by the Civil War. In their sketches and tales they had given anticipations of the work of Richard Malcolm Johnston, Joel Chandler Harris, William N. Harben, and Mary N. Murfree.

It is a noteworthy fact that the character of the negro is entirely absent from the writings of the early Southern humorists. This does not, on the whole, seem difficult to explain. Men like Longstreet, Thompson, Baldwin and others of their class could not have been unconscious of the humorous element in negro character, nor altogether unaware of the picturesque features of their dialect. Yet the negro in slavery did not seem to men

28. Rutherford, p. 309. 
of that day appropriate material for literature. He was the subject for controversy and political debate, not for literary portrayal. When the end of the war revealed more fully the pathos of the negro's situation, when his virtues had been tested by the trials which the Southern men and women had endured during the conflict, and when the days of slavery had receded far enough to be endowed with something like romantic interest, then, and only then, could the true literary possibilities of negro character and dialect be rightly understood. 


\section{CHAPTER IV}

The Period of Transition-1860-1870

The literature of the New South may be said to begin in the decade from 1870 to 1880 , with Richard Malcom Johnston's stories of Georgia "Cracker" life, George W. Cable's tales of the Creoles, Joel Chandler Harris's legends of the plantation, and Mary N. Murfree's pictures of the Tennessee mountaineer. The years from 1860 to 1870 form a period of transition in Southern life and literature. Strictly speaking, the period of transition may be sairl to extend slightly beyond the latter date, but these limits are sufficiently exact for the present purpose.

Although the events of this period were soon to lead to a striking outburst of literary activity, the period itself contains very naturally little to record in the history of the short story. The few Southern magazines which continued a somewhat struggling existence during the years of the Civil War show a marked scarcity of material in this department of fiction. The Southem Literary Messenger continted to appear till January, 1864. DcBow's Recicau, commercial largely with a few literary features, suffered a break in its life from August, 1862, to January, 1866. The Southern Field and Fireside began in 1860 and ran till 1865. In May, 1866, The Land $W_{c}$ Love was founded in Charlotte, N. C., by Gen. D. H. Hall and continueil till March, 1869. The Southcrn Home Journal was commenced in Baltimore in 1867. The Southern Magasinc, which took the place of the Now Eclcctic, ran from 1871 to 1875 . From these sources and from some of the newspapers of the period, a moderate amount of fiction was still issuing, but its quality will hardly entitle it to more than a passing notice.

A few writers of some note belong to this time. Marion Harland (Mrs. Edward T'erhume) had begun her work in 1853 by a short story in Godey's Iady's Book, ${ }^{1}$ and continued as a con-

1. "Marrying through Prudential Motives," Godey's Magazine and Lady's Book, March, 1853. Both Prof. Carl Holladay and Miss Rutherford, in their histories of Southern literature, make it appear that 
tributor to this periodical during the period under discussion. John Esten Cooke, "Christian Reid" (Mrs. Frances Fisher Tiernan) and Moncure D. Conway have magazine stories falling in these years. ${ }^{2}$ Perhaps the most important contribution to the Southern short story in these years was the little volume published in Augusta, Georgia, by Richard Malcom Johnston called "Georgia Sketches by an Old Man" (1864). Here the influence of Longstreet at once becomes apparent. The volume was in reality the foundation of the well known "Dukesborough Tales." "The Goose Pond School" and "How Mr. Bill Williams Took the Responsibility" were contained in this volume, the first of these having appeared as early as 1857.3

To this time also belong many of the sketches of Dr. George W. Bagby, although some of his short stories were produced during his period of editorship in Lynchburg in the forties, and the "Mozis Addums" letters of 1858. .

An examination of the magazine tales by other writers than those just mentioned shows that no advance had been made over the fiction of the previous period. Many of the same faults continue to appear in the stories of such periodicals as The Southern Field and Fireside and others that have been mentioned. Mary E. Bryan, ${ }^{5}$ writing in The Southern Field and Fireside, August 11,1860, comments on the false sentiment in the writings of women at that period, of the "sad dissatisfied and half reckless spirit dimly apparent in our literature, especially the periodical literature that is more fully reflective of the social life and general feelings and opinions of our age."

Although the poetry in periodicals of that time is strongly affected by the events of the Civil War, we find no short stories at that time founded upon these events. The time had not come for a representation of this period in fiction. A detachment of

this story was published in Godey's when the author was sixteen. It seems that it was written when she was sixteen (see Mary Forrest's Women of the South). The above date shows that it did not appear in Godey's till six years later.

2. See Chronological List, appended to the text, p. 101.

3. Baskervill: Southern Writers, Vol. II, p. 63.

4. So. Lit. Mess.

5. Tardy: Southland Writers, p. 645. 
a decade or two was needed for this. Indeed, when we consider the absorbing character of the struggle, the disorders of the immediately ensuing years, and the almost insuperable obstacles to publication in the South at this period, it seems surprising that her people could then foster literary enterprise of any kind. What literary life had hitherto been stirring in this section suffered inevitably an arrest of development. The political issues of the time had for some years absorbed the attention of the very class from which literary activity might have been expected. The causes of a dearth of material in this period of our study are, therefore, too patent to need explanation.

Yet even in this period when the literary outlook of the South seemed most discouraging, here and there in the magazines a note of hope is sounded showing that some expectation of a literary awakening in the South had been found in the minds of some even during the years of the Civil War. A writer in the Southern Literary Messenger for May, 1862, discusses "The Intellectual Future of the South." He explains partly the causes of the conditions of letters in the South, and predicts a great awakening of literary activity when peace should be restored and life should become settled once more on its proper basis. The writer of this article could wot then foresee the point of exhatistion to which the South would be brought, but his general conclusion was sound, since subsequent events verifieil his prophecy. 


\section{CHAPTER V}

\section{The Southern Renaissance}

It was not until the close of the Civil War and the period of settlement immediately following this that conditions in the South were entirely favorable tc authorship. It was the complete change in Southern institutions and Southern views that produced these conditions. The effect of slavery upon the literary life of the South has generally been misunderstood by writers outside of this section. It was not that the moral effect of slavery upon the men and women of the South was such as to cause a deadening of their finer sensibilities, making them mresponsive to the feelings from which the literary impulse springs. As a matter of fact, there was no section of America where pure literature was more keenly appreciated than in the old South. The truly injurious effect of slavery upon the literary life of the South was its tendency to foster the growth of an aristocratic class ivith feelings opposed to professional authorship, to clisperse rather than to concentrate population, and in a measure to hincler the wide spread of educational advantages. In a word, Southern life was largely agricultural, and it was slavery that had made it convenicut for it to be so. The removal of slavery, then, changed materially the conditions of Southern life, and thus operated with other causes to produce a literary revival after the Civil War. We may now note briefly the conditions that proved stimulating to authorship in general and especially to the production of the short story.

In the first place, there was forced upon many Southern men and women who had formerly been in comfortable circumstances the necessity of finding a prompt means of earning a livelihood. The fecling of opposition to a professional literary life now promptly gave way before the pressure of urgent necessity. There were still many cases where writers showed some reluctance in this matter, but this was chiefly due to modesty and the shrinking fron criticism.

But it was not alone the matter of pecuniary need that caused a revival of letters in the South. It was the war itself that 
furnished the chief stimulus to literary effort. The incidents and the outcome of the struggle had left a profound impression upon the mind and heart of every Southerner. The emotions of a people had been deeply stirred, and literary ttterance was a necessity. It has often been observed that a victorious war is usually followed by a period of literary activity. To the South, a war of defeat was more stimulating to literature than a war of success would have been. The Southerner felt that he had been crushed, but not defeated. He could feel pride in the separate achievements of the struggle, while sorrowing at the final loss of his cause. The emotional effect upon him was greater than if he had been completely triumphant. It was now a duty resting upon his heart to tell faithfully the inner story of that war, and to reveal the true dignity and beauty of that system of life which it had destroyed.

A richer field for the writer of fiction could hardly be found. The memory of the war furnished countless incidents that for tragic interest and cleep pathos coulil scarcely be excelled. The fine aristocratic life of the Old South abounded in picturesque features. The life and character of the negro was awaiting sympathetic literary interpretatioin. The momntaineers were still an almost unknown people. The rich field afforded in the Creole life of Louisiana was as yet untouchel. Notwithstanding the abundance of humorous sketches, the inner life and character of the "Cracker" had not yet been portrayed.

Next we may observe tlat not only were the conditions generally stimulating to authorship in fiction, but also that they wcre highly favorable to the special form of the short story. One cause of this has already been mentioned, the matter of pecuniary need. The magazine story offered a more prompt and lucrative return than any other form of literary work. It could be undertaken with better chance of success than lengthy fiction, and therefore invited effort on the part of writers who would have shrunk from the novel as a hopeless task. Again, the character of the material was such as to lend itself readily to treatment in the form of the short story. The recent experiences of the men and women of the South had stored their momories with many separate incidents of deep interest. The character of these incidents was ustially such that their tragic or pathetic interest would 
be heightened by separate treatment. Again, many special phases of Southern life that had hitherto been unknown, offered better material for brief simple pictures than for sustained narrative. Lastly, the humorous element in Southern life could be made most effective in short episodes. For these reasons, it was not unnatural that when Southern life found its full expression in literary form, the short story should become the predominant type.

In discussing the development of the various forms of the short story in the South since the Civil War, it will be impossible to preserve strict chronological order. The different forms were being developed side by side. Tales of the Old South, negro dialect stories, stories of the mountaineer, the "Cracker" and the Creole, were all being written at approximately the same period. If we take these classes of stories in the order of their appearance, we find the "Cracker" story coming first, next the Creole story, then the negro dialect story, and last the story of the mountaineer.

The first type begins with the stories of Richard Malcolm Johnston, who took up the line of work started by Longstreet. Mention has already been made of "The Goose Pond School" (1857) and "Georgia Sketches by an Old Man" (1864). This volume was supplemented by four stories, and issued in Baltimore in 1871 as "Dukeshorough Tales, by Philemon Perch." Cable's stories of Creole life began appearing in Scribner's Monthly, now the Century Magazime, in 1873. Joel Chandler Harris's first Uncle Remus story, "Brer Rabbit and the Tar Baby," was published in the Atlanta Constitution in 1877. Mary N. Murfree's first tale of the Tennessee mountains, "The Dancing Party of Harrison's Cove," appeared in the Atlantic Monthly in 1878. These different types of the Southern short story will now be briefly discussed in the order of their appearance. 


\section{CHAPTER VI \\ Stories of "Cracker" Life}

Richard Malcolm Johnston's career as a professional author began so late in life that he is contemporary with the later school of writers since the Civil War, although in early manhood he was identified with the Old South. Born near Powelton, Georgia (the Dukesborough of his stories), and passing his early life in this village, he gained an intimate knowledge of middle Georgia life. In his practice as a lawyer he had opportunities for observation similar to those of Longstreet. His stories are the reports of an eye-witness. He has told the story of narrow unromantic lives heightened in interest by amusing incidents, eccentricity of character, and at times by quiet pathos. His best work is found in his short stories, as he lacked the power of sustained narrative. Johnston was reared in a family typical of the best features of Georgia life at that periorl. Many of his stories are reflections of his childhood experiences. For example, the country Stmday is portrayed in "Puss Tanner's Defense" and "How Mr. Bill Williams Took the Responsibility." From Johnston's stories a good deal of information can be gathered concerning the intellectual and social conditions in that part of the South. The life that Johnston knew in his youth was not very different from that depicted in Longstreet's Georgia Scenes. ${ }^{1}$ Johnston's portrayal of character, however, is far more complete. The influence of Longstreet may be clearly traced in "The Humors of Jack Bundle," "The Various Languages of Billy Moon" and "King William and His Armies."

Johnston's early volumes of 1864 and 1871 have been already mentioned. In 1883, an edition of "Dukesborough Tales," containing sixteen stories, was issued by Harpers. To this volume Johnston, for the first time, prefixed his name. The stories composing the first volume had appeared in the Nerv Eclectic and the Southern Magazine. ${ }^{2}$ The fact that Johnston received no

1. See "Middle Georgia Rural Life" by Richard Malcoln Johnston. Century Magazine, March, 1892.

2. See reference to these periodicals, p. $4 \pi$. 
compensation for these early stories furnishes a commentary upon the literary conditions in the South at that time. It was not till 1879 that Johnston placed sufficient confidence in the merit of his work to submit it to Northern magazines. Sidney Lanier persuaded him to offer "Mr. Neelus Peeler's Conditions" to Scribuer's Monthly, now Century. Its acceptance marked his definite entrance upon a literary career.

The village of Powelton, Hancock County, Georgia, has been mentioned as the "Dukesborough" of Johnston's stories. The region which he describes had been settled by a hardy race, many of them emigrants from Virginia. In the early days the conflicts with the Indians and the labors attending the development of a new country had fostered the growth of sturdy virtues, while the necessity of amusement to lighten the monotony of uneventful country life had developed a homely type of humor and some degree of wit and vivacity in conversation. The "Crackers" of Georgia occupieil a very different position from that of the class known to literature as the "poor whites." There was simplicity in their lives, but there was also thrift, economy, and cheerfulness, with none of the iepressed, abancloned feeling characteristic of the genuine "poor whites." They displayed the traits common to the small farmer class the world over, with some distinct local peculiarities. In the account of Longstreet's work, reference has already been made to the unified character of Georgia life at that period. The absence of sharp social distinctions and the freedom of association among all classes accounts largely for the frce, racy spirit of humor so characteristic of this section.

The religious life and denominational controversies of the communities with which Johnston was familiar furnisheil him with many entertaining scenes. There was a lively interest in church matters. Doctrinal discussions were often long and bitter. Monthly stated meetings and conferences were occasions that often displayed his characters in their most entertaining and amusing light. All such topics, however, are treated by Johnston in a fine spirit of tolerance. Matrimonial affairs occupy a. place in his stories no less prominent than the one which these matters held in the minds of the good country folk whom he has described.

The negro is almost entirely absent from his stories. "Moll 
and Vergil," his only story in which the negro is prominent, presents a strong picture of the negro's faithfulness to his master in time of misfortune.

Johnston's limitations as a writer are evident. His field was a narrow one, and consequently he was hampered by a limited range of characters and incidents. It is a proof of his ability, however, that within this limited field he produced so many stories of decided merit. As might naturally be expected, the interest of his stories depends upon the quaintness and humor of his characters, not upon skill and novelty in his plots. There is even at times a little incoherence in the structure of his stories, and a slight absence of strength in the climax. The reader does not find himself startled by unexpected conclusions. The "Pursuit of the Martyrs" is the one exception to this statement. The stories embody merely the simple incidents of village gossip, told with fine realism and keen discernment of cliaracter.

Johnston's habits of prefixing poetical quotations to his stories is suggestive of the main literary infuences under which his stories were composed. The nineteenth century English novelists were evidently his masters in fiction. His general method looks back rather to the generation that had just passed than to the one in which he wrote. His method is quiet and discursive, rather than intense and concentrative. Yet in this very respect his manner was suited to his material; for in no other way could he have given an entirely faithful picture of Middle Georgia life.

The comments that have been made on the early work in Johnston in his "Dukesborough Tales" apply as well to a large number of stories that he produced in later years. Until his death in 1898, he continued to be among the most prolific of Southern writers. His later collection of short stories are as follows: "Mr. Absalom Billinglea and other Georgia Folk," 1888; "The Primes and their Neighbors," 1891 ; "Mr. Billy Downs and his Likes," 1892 ; Mr. Fortner's Marital Clains and Other Stories," 1892 ; "Little Ike Templin and Other Stories," 1894; "Oli1 Times in Middle Georgia," 1897.

The portrayal of Cracker life in which Johnston had been so admirably successful was continued in some of the stories of Joel Chandler Farris. "Mingo" presents a picture of "Cracker" 
prejudice against the negro, on the one hand, and the aristocratic class, on the other. Characters from the same class appear in "Blue Dave," "Free Joe," " A Piece of Land," "Where's Duncan ?" and "The Old Bascom Place," although these stories do not deal exclusively with the "Cracker" type. Mr. Harris's familiarity with all phases of Georgia life enablecl him to portray such characters with no less fidelity to his subject than he has shown in his negro dialect stories. The narrowness of view, the strength of prejudice, the homely wisclom and quaintness and vigor of expression belonging to this class are all admirably portrayed.

Harry Stilwell Edwards, in his two collections of short stories, "Two Runaways and Other Stories," and "His Defense, and Other Stories," has given excellent pictures of the same class. "His Defense" opens a view into the inner life of a Georgia rustic that is at once quaintly humorous and gently pathetic. "Elder Brown's Backslide" was the first of his prominent stories, and is an exceedingly human picture. Nowhere has Mr. Edwards succeeded in presenting more admirably the contradictions of human nature than in "Sister Todhunter's Heart." The skillful portrayal of the leading character is not the only striking feature of the story. The keen observation and nicety of touch shown in the personal descriptions of this picture of village story life show to excellent advantage the best qualities of Mr. Edwards's work. In the stories that have been mentioned, as in all of his fiction, he shows careful attention to the structural side of his work, always succeeds in securing unity of action, general harmony of tone, and effective climax.

William N. Harben, in his "Northern Georgia Sketches," presented the up country "Cracker," more frequently the genuine "poor white" class. Although this volume was issued in 1900, most of the stories had appeared in magazines before that year. The most forcible quality in Mr. Harben's stories appears to be the utter simplicity and directness of his method. There is no appearance of what we might call literary embellishment. This style expresses admirably the very tone of the simple, uncultured life that he describes, and (conveys effectively an impression of realism. "The Rural Visitor" shows more of humor than the 
STORIES OF "CRACKER" LIFE.

other stories. "The Filial Impulse" and "The Tender Life" are the best examples of quiet pathos.

The Georgia "Cracker" has had few more sympathetic interpreters than Matt Crim. Her volume of stories, "In Beaver Cove and Elsewhere," contains studies in Georgia life and character taken largely from this class. In the preface of her work, she thus briefly summarizes the "Cracker" traits: "It is rare for the 'Cracker' to have any book learning, nor cloes he desire it, but it is the rule and not the exception for him to have plenty of shrewd common sense, a keen appreciation of humor and certain heroic qualities developed by the pioneer life of his forefathers. $\mathrm{He}$ can be cruel and suspicious or friendly and hospitable. He may drive a hard bargain with a tracler, but freely lend his ox or his ass to a needy neighbor."

The first of her stories to attract wide notice was "An Onfortunit Creetur," which appeared in the Century for February, 1886. It is the old tale in new setting of fine heroism in a humble and seemingly worthless life. This, as most of Miss Crim's stories, is drawn from real life; the author states in her preface that the "Onfortunit Creetur" and his sister "Peggy" were both personally known to her. As even as is the general quality of her work, none of her later tales excel this cne in true human quality and pathos, or in unity of structure and well-developed climax. 


\section{CHAPTER VII}

Stories of Creole Life

GEORGE W. CABLE

When "Sietur George" appeared in Scribure's Monthly, now the Century Magainin, in October, 1873, Cable had opened a new and uniquely interesting ficld of literature. The life of the Creole, rich in literary possibilities, was then but little known to the outsicle world. Cable's first literary venture had not met with the favor of the publisher. "Bras Coupe," which he afterwards used as the basis of "The Grandissimes," had been previously offered to Scribncrs, but had been rejected." Success, however, was not far off. By Junc of 1877 he had contributed "Belles Demoiselles Plantation;" "Title Poulette;" "Jean-ah Poquelin;" "Madame Délicieuse;" and "Café des Exiles."

Cable had begun his literary career on the stati of the Now Orlcans licayunc. A youth of privation and hard work had been followed by two years of active service in the Confederate army, when he returned to New Orleans, which then offered so rich a field for the writer of romance." With the skill of an artist, he began picturing the deeply suggestive life around him in the exquisite bits of fiction which lave been mentioned. These stories were published in 1879 as "Old Creole Days." They are terse and vivid narratives, possessing a high degree of artistic finish, tender pathos, and at times a delicate play of arch humor. In these tales the clelicacy and grace of the Latin race is shown in subtle unior with the sturdy fibre of the English stock. The process in Cable's literary development which is described in Baskervill's "Southern Writers" as "the struggle between the artist and the man with a mission" had not yet begun. ${ }^{3}$ The partisan feeling which in his later work dulled to some extent his artistic sensibility is not present in these early stories to mar their beauty.

1. Baskervill's "Southern Writers," p. 317.

2. W. S. Harwood's "New Orleans in Fiction." (Critic, 47: 426.)

3. Page 320, Vol. I. 
With the publication of these stories the Creole became one of the established types in Amierican fiction, and it is Cable who has been chiefly instrumental in preserving the picture of this interesting and picturesque type of Southern civilization. The land of the Creoles comprises the southern half of the state of Louisiana. It is a region of rich plantations, interspersed with bayous, lakes and swamps, with dark forests of live oak and cypress draped with hangings of Spanish moss. The soft languid air seems in keeping with the gentle speech and guiet manners of the people, while the weird beanty of the scenery furnishes an icleal background for romance.

But it is the Creole of the city whom Cable chiefly clescribes in his short stories. There he is seen to best advantage; for the social instincts are given full play, and the light-hearted gaiety and quick fancy of the race have their proper setting. New Orleans, with all that is quaint and picturesque in outer aspect and life, is set forth in his stories with an artist's fidelity. Quiet, narrow streets, with picturesque architecture, suggestive of a romantic past, arcaded sidewalks, antique buildings, with round tiled roofs, high fenced gardens, with palm and banana and orange trees and luxuriant flowers-these are some of the materials for his artistic pictures.

Cable's work exhibits the modern method in the short story. The plot is usually extremely simple. The narrative moves rapidly and directly to its end. The setting is handled with great skill and the characterization is clear and definite. The actors do not exist as figureheads merely to assist in the furtherance of the plot. It is the heart problems of the characters that make up the life of his stories. The events are often of the most simple and natural occurrence. It is the moral situation which gives interest to his stories. A definite impression is left upon the mind of the reader and the character lives in the mind as a distinct personality. All the incidents of the story may fade from the mind, but it is not easy to forget the picture of Sieur George and his trunk filled with lottery tickets. Madame Delphine stands out vividily in the moment of her falsehood anil confession, "Posson Jone" in the hour of his humiliation and "Jean-ah Poquelin," as he secretly guards with dogged tenacity his Leprous brother in the swamp. 
As has already been noted, these are stories of character and situation rather than stories of incident. The ethical teaching, however, is never forced upon the reader. Indeed, the moral is not always quite satisfying. We might wish that Madame Delphine had not sullied her conscience with a lie or that "Posson Jone" had not fallen from rectitude, yet as pathetic pictures of human frailty they are drawn in indelible lines.

"Strange True Stories of Louisiana," published in 1888, are somewhat tinged with the spirit of the partisan. They belong to the period of his controversy in regard to the political and social status of the negro in the South. They belong more strictly to the department of the historical sketch than the short story, and should be tested for historical accuracy rather than for artistic method. As specimens of narrative, "The Haunted House in Royal Street" and "Attalie Brouillard" are the most striking and effective of the sketches.

"Bonaventure," issued in 1888, consists of three stories: "Carancro," "Grand Pointe" and "Au Large," which had appeared separately in the Century. They deal with the Creole life of the country. Their merit is not found in plot construction, but in skillful characterization and charming description.

Cable's presentation of the Creoles has been assailed in Louisiana. ${ }^{4}$ He has doubtless been guilty of some mistakes and misrepresentations, but he did not attempt to present every phase of Creole life and it must be remembered that he was often describing exceptional characters. The skill, the artistic finish, and the human sympathy displayed in his work must furnish some apology for any lack of historic accuracy.

\section{GRACE ELIZABETH KING}

George W. Cable's chief rival in the portrayal of Creole life has been Grace Elizabeth King. Her ancestry shows a mingling of English, French, Scotch and Irish blood. In her childhood she knew New Orleans when the rich picturesque life of the city was in full bloom just before the Civil War. Living on her father's plantation in lower Louisiana, she witnessed the changes wrought by the war, and experienced all the disorders of the Reconstruc-

4. See "Cable and the Creoles" (Critic, 4: 298). 
tion period. Her aim as a writer has been largely historical-to give truth where she had seen misrepresentation. As secretary of the Louisiana Historical Society, she has had access to the original sources of the French and Spanish history of her section, and she has therefore had abunclant means of securing accuracy in her work. Her admirable historical work, "New Orleans, the Place and the People," shows how sound a basis she possessed for her work in fiction. In some respects her representation of the Creole life is regarded as nearer to the truth than Cable's. She has reproduced the atmosphere of that life with no less ficlelity, she has shown a true sympathy with the people she described, and her picture of Creole women in particular are more complete and satisfying.

Her short stories began with "Bonne Maman" in Harper's for July, 1886. In the same magazine one year later appeared "Bayou L'Ombre," and in December, 1888, "The Christmas Story of a Little Church." These stories, together with "Madrilene; or the Festival of the Dead," (Harper's, November, 1890), and "In the French Quarter," (1870), composed her first volume of short stories, entitled "Tales of a Time and Place," (Harper and Brothers, 1892).5 Her "Balcony Stories" began appearing in the Century in 1892, most of them belonging between January and November of 1893 . These appeared in a volume in 1893.

The stories of these two volumes are distinguished by certain obvious external differences. In "Tales of a Time and Place" the stories are longer and more carefully elaborated narratives. "The Balcony Stories" are brief, dramatic scenes. In the first volume "Bonne Maman" and "Madrilene; or the Festival of the Dead" are the two stories of greatest power. The first draws a pathetic picture of the privations of Southern women just after the Civil War; the second tells with an almost fierce power a tragedy founded upon the question of tainted blood. This theme, frequently handled in stories dealing with this section of the South, had also been presented in "The Little Convent Girl," one of the "Balcony Stories," as well as in Cable's

5. The date of this work is given in most works on Southern Literature as 1888. See, for example, Trent. 
"Madman Delphine" and "Tite Poulette;" Kate Chopin's "Désirée's Baby;" Mrs. Davis's "The Love Stanche;" and Matt Crim's "Was it an Exceptional Case," a tale of Marietta, Georgia. "Madrilene" marks one extreme of Miss King's range in fiction and the "Balcony Stories" the other. The story, on account of its weird and sombre tone, has frequently led to comparison with the style of Poe. ${ }^{6}$ It is intense, vigorous, thrilling with a sort of passionate energy, and sharpened at times by a touch of sarcasm. Suggestion is used to full effect. At the point where the action becomes most rapic and dramatic, all explanatory phrases usually employed in reporting conversation are dispensed with, and the words of a dozen speakers crowd upon one another in a mad rush of words that conveys vividly the intense scene that is being enacted. It is a forcible example of the manner in which the moclern short story has incorporated something of the method of the drama.

The "Balcony Stories" as their name suggests, are tales such as the women of New Orleans tell as they sit and talk together on summer nights on their balconies lighted only by the stars or the pale moonlight sifting through the vines, the narratives weaving together "Experiences, reminiscences, episodes, picked up as only women know how to pick them up from other women's lives,-or other women's destinies, as they prefer to call them,and told as only women know how to tell them."'

These stories are simple and condensed, told with a French conciseness and point, revealing some single scene of tragedy and passion or some sittlation of quiet pathos. Within their brief compass they illustrate forcibly the moclern conception of the short story, with its economy of structure and singleness of effect. In their brevity and suggestiveness, they are an admirable expression of that society which the author herself knew so well and in which-to use her own expression in one of her own stories-"an allusion is all that is necessary to put one in full possession of any drama, domestic or social." 8

Some of the stories are in reality only sketches. "A Cripple's Hope," for example, is an exquisitely tender description of an

6. Baskerville: Southern Writers, p. 285.

7. Preface to "Balcony Stories," p, 2.

8. "A Delicate Affair," in "Balcony Stories," p. 210. 
old slave woman. "The Miracle Chapel" and the "Story of a Day" should likewise be classified as sketches. As specimens of the short story in its simple form, "A Drama of Three" and "Anna Marie and Jeanne Marie" are striking examples of what may be accomplished with a very simple situation by skill and delicate handling. For the combination of humor and pathos with keen insight into character, "A Delicate Affair" and "Purpasse," a little tale of convent life, are the most noteworthy in the collection.

\section{MRS. KATE O'FLAHERTY CHOPIN}

George W. Cable and Grace King treated chiefly the Creole life of the city of New Orleans. The setting of the work of Mrs. Chopin was principally central Louisiana. Kate O'Flaherty, born in St. Louis in 1851, and educated at the Convent of the Sacred Heart, married in 1870 Oscar Chopin, a cotton merchant, and spent the next ten years in New Orleans. A few of her stories have their setting here. "Tante Cat'rinette" (Atiantic, July, 1894) and "Neg Creol" (Atlantic, Sept., 1897) are examples of this class.

In 1880 the family moved to a plantation in Natchitoches Parish, and here living for two years near the little village of Cloutiersville, she came in contact with the life which furnished her with her chief literary material. "Bayou Folk" (1894) and "A Night in Acadie" (1897) are her collections of short stories.

In her village life all classes of the population about her came under her sympathetic notice, and have been presented in her stories with entire sincerity. She treated usually the ordinary occurrences of life, but, with true story teller's art, reproducing faithfully the atmosphere of the life she described. The mingling of Irish, French and English blood in her veins shows the hereditary influences under which she worked. There is a distinct French quality in her style. Simplicity of outline, proportion, precision and grace are present in her tales. Such stories as "Madam Celestin's Divorce" and "Désirée's Baby" entitle her to high rank among American short story writers. 


\section{CHAPTER VIII}

\section{Stories of Negro Dialect and Character}

When Joel Chandler Harris began contributing his first Uncle Remus skctches to the Atlanta Constitution in $1876,{ }^{1}$ the negro had, up to that time, received very little attention in pure literature. He had been made the subject of numerous political treatises, but the artistic possibilities of his character and dialect had not been realized, and the humor and pathos of his condition still remained tnexpressed. We have already remarked on the inconspictious place which the negro occupied in the literature of the Old South, and have pointed out the reasons for this fact.

There were, it is true, a few instances in which negro character had been briefly presented in the earlier period. John $P$. Kennedy gave sketches of negro character in the slave quarters in "Swallow Barn" and drew one picture of negro heroism that has already been mentioned. ${ }^{2}$ Poe had used the negro Jupiter to adil a humorous element to "The Gold Bug." Simms had shown some of the darker features of negro character in his tales "The Wigwam and the Cabin."

After the Civil War the nation at large was first introduced to negro dialect through the early stories of Katharine Sherwood Bonner and the poem of Irwin Russell, "Christmas Night in the Quarters" (Scribner's Monthly, June, 1878). Sherwood Bonner, a native of Holly Springs, Mississippi, had left her home in the South after an unfortunate marriage in 1871, and had gone to Boston to make her way in literature. She had previously published two stories: "Laura Capello," in the Boston Plozeman and "A Flower of the South" in a musical journal." Before 1878, she had published some of her "Gran'mammy Stories." These were perhaps the first negro dialect stories to appear in a Northern magazine. Her "Dialect Tales," published

1. Baskervill: Southern Writers, Vol. 1, p. 61.

2. Page 8.

3. Baskervill: Southern Writers, Vol. II, p. 92. 
by Harper Brothers in 1883, contained several stories that will be mentioned under another heading. Among these, however, was the humorous negro dialect story, "Aunt Anikey's Teeth," which will rank with the best of its class. The collection entitled "Sewanee River Tales" was published after her death by Roberts Brothers, Boston, in 1884. In her stories she displayed a sympathetic knowledge of negro character and interpreted well its humorous features, although her representation of dialect is not so accurate as that of later writers.

Contemporary with the early efforts of Sherwood Bonner in the negro dialect story were the similar contributions of Mrs. Mollie E. Moore Davis. Mary Evelyn Moore, a native of Talladega, Alabama, was married in 1874 to T. E. Davis, who, in 1884, became editor of the New Orlcans Picaynue. Her other work in the short story will be mentioned in its proper place.

While due credit should be given to these pioneers in the field of negro dialect, Joel Chancller Harris must be recognized as the first'writer to give to the world a full and clear picture of the negro. His stories came as a revelation to the world of a civilization that had been hitherto unknown or entirely misunderstood. This fact gives to his work an enduring value apart from the charm of the inimitable stories that he told, with their wealth of folk-lore clothed in clelightful humor.

His opportunities for observing negro life had been highly favorable, but by no means exceptional among Southern boys at that period. ${ }^{*}$ He had the eye to see and the heart to feel and he learned to know the negro as others did not. A reminiscence of his boyhood reveals the element in Mr. Harris which gave him so full an understanding of negro character. He states that in his boyhood he was more deeply affected by "The Vicar of Wakefield" than any other book. Speaking of the influence of this work upon him, he says: "It touches me more deeply, it gives me the 'all overs,' more severely than all others. Its simplicity, its air of extreme wonderment, have touched me deeply and continue to touch me deeply." ${ }^{5}$ Can we not find in these words an indication of the very qualities in negro character

4. See his "On the Plantation."

5. Baskervill's Southern Writers, Vol. 1, p. 52. 
which marle it appeal so forcibly to Mr. Harris? In other words, was it not this very "simplicity" and "air of extreme wonderment" that constituted the most pathetic and at the same time the most attractive qualities in the negro as Mr. Harris knew him in his youth?

It was this spirit in Mr. Harris that gave him his unique fitness as an interpreter of negro life. With true literary insight, he had caught the very spirit of the negro race, and in the words of its own representative, he revealed this spirit to the world. It was no longer the caricature of the minstrel stage or the distorted picture of a prejudiced mind, but the negro himself as he revealed himself fully and distinctly to one who knew and understood and loved him. Through his conversations $\mathrm{Mr}$. Harris also found the means of exhibiting many important traits of Southern character, and many attractive aspects of the old Southern civilization that had been swept away.

For his special material in the "Uncle Remus" stories, Mr. Harris's narrative art is almost faultless. As stories of humorous incident, although they belong more strictly to the class of the anecdote than to the short story, their structure is well-nigh perfect, and they have the added element of vivid character portrayal. This is found not only in the human character of Uncle Remus. The innagined characters of the animals are distinctly individualized and clearly maintained. Indeed, it is doubtful whether any other characters of fiction have in the reader's mind a more clearly clefined personality than Bre'r Fox and Bre'r Rabbit and the other brethren of the woods and fields, with whom Mr. Harris has placed his readers on terms of such delightful intimacy.

Mr. Harris's abundant knowledge of the negro could not find complete expression through the Uncle Remus tales alone. What was best and most pleasing in the plantation darkey could be revealed through the personality of this charming companion of the "little boy" but there was an unlovely side to the picture as well, and $\mathrm{Mr}$. Harris did not shrink from presenting this. In "Free Joe and the Rest of the World," he set forth the forbidding side of slavery, and depicted with great force the misery that could result from the system. In another group of stories, represented by "Mingo," "Blue Dave," and "Balaam and his 
Master," we have Mr. Harris's picture of some of the social effects of slavery; the prejudice, the caste distinctions, anit the false pride of family which were encouraged by the conditions of Southern life.

It is probably true that the stories of Mr. Harris contain more solid truth about the negro than can be found from any other source. While shrinking altogether from the attitude of the conscious artist and the professional literary craftsman, he nevertheless achieved on the side of form in his tales of negro folklore a result that is well-nigh perfect. Here the element of plot does not form a large part of his achievement, but the portrayal of character leaves little to be asked.

In his treatment of negro dialect and folk-lore, Mr. Harris represented only one large section of the South. There were other dialects which naturally clid not appear in his stories. If we omit the slight local peculiarities to be found in special sections, there have been three main dialects spoken by the Southern negro. The stories of Mr. Harris and Mr. Page represent the standari clialect of the ante-bellum negro of Virginia and Georgia; and, in the main, this speech belonged to the same class of negroes in Kentucky, Tennessee and in the large part of the Carolinas. A second distinct dialect is that of the Mississippi delta, which Mr. Cable has employed in some of his work. The third and most peculiar is that known as "Gulla" or "Gullah" spoken in the coast region and sea islands of South Carolina, Georgia and the northern coast of Florida. ${ }^{6}$ Charles Colcock Jones, Jr., the Georgia historian, has made tuse of this remarkable dialect in a collection of stories entitled "Negro Myths from. the Georgia Coast, Told in the Vernacular" (Houghton, Mifflin \& Co., 1888).

Mr. Ambrose Elliott Gonzales, of Columbia, South Carolina, wrote a series of humorous stories, entitled "Silhouettes," in the same dialect. These appeared in the Charleston Neros and Courier and in the Columbia State. ${ }^{\text {T }}$

6. For an account of this dialect, see an article by John Bennett in the "South Atlantic Quarterly" for December, 1908, and January, 1909.

7. See article on John Bennett, Library of Southern Literature, vol, I, p. 327 . 


\section{THOMAS NELSON PAGE}

When we pass to the negro dialect stories of Mr. Page, we find ourselves in a somewhat different atmosphere. In the stories of Mr. Harris and Sherwood Bonner, the negro is really the central point of interest. This is true even of the plantation legends, for their highest value is in the revelation of negro character, the information concerning the folk-lore of the race, and the pectliarities of thought and expression, so well presented to the reader. In Mr. Page's stories, on the other hand, the negro is chiefly a quaint and humorous interpreter of the life of the Old South and it is really the romantic picture of that interesting civilization that constitutes the central interest of the story. In other words, the negro is present in the story, not primarily for his own sake, but for the opportunity which is thus given to the writer to present the picture in a spirit which is best suited to his purpose. The humorous exaggeration of the negro, his childlike enthusiasm, his pride and delight an show and ceremony, his loyalty and devotion to his superior,-these were just the qualities that made him a suitable medium for presenting the bygone days of Old Southern life. Seen throughi the picturesque imagination of the negro, the social life of the South before the War took on just the romantic hue that the author desired for his picture. Again, when the events of the Civil War become the subject of the narrative, the melting pathos of the scenes which Mr. Page introduces is strongly intensified when told through the medium of negro dialect and from the negro's standpoint of affectionate loyalty to the master and his family. In a word, Mr. Page's characteristic use of the negro in his stories is to emphasize the romantic and pathetic element in the life of the white man at that particular period of Southern life.

By this we do not mean that Mr. Page has not been entirely faithful in his delineation of negro character. His insight into negro character is true and penetrating, and his interpretation of their virtues is just and sympathetic. Yet the picture is limited by the fact that he makes use only of those features in negro character which are needed in setting forth the position of the white man. 
Nor, on the other hand, can any criticism be passed upon Mr. Page from the standpoint of the artistic purpose. The method he employed was exactly suited to the tone and spirit of his work and there can be no question that the remarkable success of his stories has been due very largely to the happy selection of the very standpoint which he adopted. The purpose in touching upon the difference between the method of Mr. Page and other writers is merely to set forth the various literary uses that have been made of negro character in the development of this special type of short story.

It will be observed, of course, that these remarks apply only to those stories of $\mathrm{Mr}$. Page which present the life of the Old South or episodes of the Civil War. There are many of his later stories in which the negro figures as the only prominent character. Such stories as "How Jinny Eased Her Mind," "Uncle Jabe's Marital Experiments" and "P'laski's Tunaments" exist for no other purpose except to set forth certain marked idiosyncrasies of negro character. These stories, however, do not represent Mr. Page's most characteristic work. This is to be found in the stories included in the volume "In Ole Virginia," where he employs the method already discussed. The merits of these stories have been too frequently pointed out to need further comment. The delightful humor, the tender pathos, moving yet restrained, the charming portrayal of a type of life that has passed entirely away, the satisfying tone of good breeding that pervacles them all,-these qualities are too well known to call for illustration or remark.

It has been claimed by some critics that Mr. Page's pictures of the Old South are too strongly idealized; that there is too much glamour and too little hard truth; and that in the effort to glorify the past he has misled the readers of the present. It must be said, of course, that in Mr. Page's temperament there is more of the romanticist than the realist. Yet we do not feel that it can be claimed that he has not truthfully depicted the life that he knew so well, both from personal experience and family tradition. To idealize is not necessarily to falsify. The literary artist must select from the abundance of his material only those details which will convey a vivid impression of what is most essential in his picture: To omit other details is not to deny 
their existence; it is only not to write another story. Again, it must be borne in mind that Mr. Page's descriptions attempt to furnish no general picture of conditions in the South. They are drawn for only one section and for a very limited circle of the people in that section. The fine old aristocratic life of Virginia is the true subject of these short stories, and Mr. Page has done a faithful service when he preserved it in these charming tales.

Other types of his short fiction will be mentioned at a later point in this work. Before conclucling, however, the discussion of the present part of his work, some attention should be given to the structure of his stories since they are the best representatives of the short story most highly typical of the New South. During the period immediately following the appearance of his early stories, Mr. Page was unquestionably a model and an inspiration to many other writers in the South. The influence of his work is acknowledged by Mr. Harry Stillwell Edwards and others who have portrayed Southern life. Mr. Edwards says in a letter to the author: "For myself I may say that in the early 'Eighties,' after experience as a newspaper reporter, paragrapher, and sketch writer, I read Thomas Nelson Page's 'Marse Chan' and became enthused over it. Immediately I took up the unwritten legends and stories of this section and treated them in much the same way. Where Page's inspiration came from I cannot say, but I am sure in my own mind that he is the real literary father of the Southern short story as we know it in this day."

As Mr. Edwards here points out, Page's stories exhibit the features of the typical Southern short story; that is, the simple tale of true human incident and emotion, placed in an attractive setting of cld Southern life. In the telling of such a tale charm of manner, genial humor, pathos and true human feeling count for more than rigid principles of short story structure. As we read such stories as those of Page we feel instinctively that the author wrote from the heart rather than from the intellect. The story is artistic because it is true and human, not because the author was obeying rigid principles of literary technique. In other words Page's structure seems natural rather than de- 
signedly artistic and this quality is one that is characteristic of the large mass of typical Southern short stories.

Many exceptions, of course, occur. In the chapter on the stories of Creole life and in other parts of this work, authors are discussed whose stories exhibit close adherence to what has been described, chiefly in the clapter on Poe, as the typical modern short story method. John Fox, Jr., Grace King, Mrs. Kate Chopin and Mrs. Davis show frecuent examples of this method. These authors among others may be said to represent one structural type of the Southern short story while Page, Harris, Edwards, Allen and others represent another type. In the one the method of structure seems evident and designed. In the other simplicity of form seems to come from emotional instinct rather than from design.

\section{FARRY STILLWELL EDWARDS}

Among the writers who have iescribed the negro of slavery days few have succeeded more admirably than Mr. Edwards. Born in Macon, Georgia, he has resicled all his life in this state, except during a brief period of government employment in Washington. After an unsuccessful attempt at the practice of law, he began his literary career with contributions to the Waverly Magazine of Boston. Soon after this he became local editor of the Macon Telegraph and was made associate editor in 1881.

His prominent short stories of negro character began with "Two Runaways" (Harpers, July, 1886). Following this came "De Valley an' de Shadier" (Century. June, 1888); "Minc-a Plot" (Century, December, 1888); and "Tom's Strategy" (Century, May, 1889). These are all included in the volume "Two Runaways and Other Stories." The humor and fine discernment of negro character shown in "Two Runaways," the pathos of "Ole Miss" and "Sweetheart" and "De Valley an' de Shadder" give these stories a prominent place in the fiction of their class. The character of Isom is among the best portrayals of the plantation negro in Southern literature. The stories that continued to center about the characters of Colonel Crawford Worthington and Isom bring down the careers of these two heroes through the Civil War and form a large part of Mr. Ed- 
wards' second volume of short stories "His Defense and Other Stories." In this latter volume "Captain Isom" is one of the best pictures that has ever been drawn of the negro's bravado and inborn cowardice. "The Gum Swamp Debate" shows Mr. Edwards at his best in the command of negro language and general viewpoint.

The stories of the volumes just mentioned represent chiefly the negro since the days of slavery and all aim to present merely some humorous feature of negro character.

VIRGINIA FRAZER BOYLE

Virginia Frazer, a native of Chattanooga, Tennessee, married in 1884 Thomas R. Boyle, a Memphis lawyer. Although she is known chiefly through her poems, she has written many dialect stories and tales of negro folk-lore. Her "Devil Tales," which form her chief collection of negro stories, was publisheil in 1900, although some of the stories of this volume had appeared in magazines before that year. She has presented chiefly the weird and mysterious side of negro lore. Superstition and odd fancies illustrating the imaginative temperament of the negro have formed the basis of her work.

\section{WILLIAM N. HARBEN}

Mr. Harben, of Georgia, has brought out certain aspects of the negro's life in slavery that no other writer has dealt with in just the same manner. In his "Northern Georgia Sketches," several stories present very forcible pictures of negro life in upper Georgia. "An Humble Abolitionist" describes the relation between the slave and the "poor white" in a very forcible way, showing the negro's feeling of superiority and his unwillingness to be dominated by any except the upper class of the whites. "The Whipping of Uncle Henry" depicts the negro in rebellion against plantation discipline and introduces some of the unfortunate features of the overseer system. There is a simplicity and force in the presentation that belong to all of $\mathrm{Mr}$. Harben's "Northern Georgia Sketches."

\section{MAURICE THOMPSON}

The discussion of the race problem in the South since the Civil War has necessarily exerted an influence upon the presen- 
tation of thie negro in fiction. One of the direct effects was the production of stories posing certain problems that grew out of the status of the negro in society. In 1889 Maurice Thompson began a series of stories in the Century. Many of them were negro stories in which the author set forth certain political and social views relative to the race. "A Race Romance" (Century, April, 1891), for example, is a Georgia story representing the dangers and perplexities brought about by the educated and emancipated negro. In these stories there is fortunately enough of true humor and pathos, combined with genuine character portrayal, to prevent them from being overburdened with their moral.

\section{MRS. RUTH MCENERY STUART}

We have noted the special standpoint adopted by Mr. Harris and Mr. Page and the particular fields covered by other writers of negro stories. Mrs. Ruth McEnery Stuart has chosen still another field. The plantation darky of the Old South had been fully portrayed by Mr. Harris and Mr. Page. His relation to his master in the days of slavery had been clearly set forth and through him the system of life in the ante-bellum South had been clearly revealed. It remained to picture the negro of a later time for his own sake, to portray his home life, his problems, his virtues and his faults, enlivened by all the oddities and peculiarities of his race. This in some measure Mrs. Stuart has sought to do. Within this province she has dealt chiefly with the lighter and more amusing side of life, and has not attempted to pose profound problems. She has had no doctrines to promulgate, no race problems to discuss, no mission to perform. Her optimism has naturally inclined her to present the joyous and hopeful phases of lifc. Pathos, it is true, forms no small element in her work, but it is always subdued and never allowed to run into melancholy.

Mrs. Stuart's most effective touches in her stories are due to the skillful adaptation of dialect and viewpoint to bring out precisely the negro's attitude toward the situation presented to the reader. Her general skill in monologues has given her marked ability in presenting the somewhat discursive type of negro conversation. Her intimate knowledge of negro character 
grew partly out of her early life in New Orleans, but chiefly from her residence on the Arkansas plantation of her husband, Alfred $O$. Stuart. From these sources she gathered the material for her three types of stories; those dealing with the negro, the Latin American, and the Arkansas rustic. The stories of the last two classes will be mentioned later.

In her stories, Mrs. Stuart has usually employed simple plots and devoted her attention chiefly to characterization. This is largely the secret of her accurate portrayal of the types that she introduces into her stories. She has not confined herself to any one class of negroes. She has described some of the lingering specimens of the old Southern darky in their life since the War, and she has also depicted the life of the present generation. She has described the negro in the country and in the city, in scenes both of pleasure and sorrow.

It would be difficult to settle the question of precedence among her large number of entertaining stories of negro character. Each reveals some special side of her talcnt. "A Golden Wedding" shows her gentle sympathy with the negro in his elemental emotions; "Moriali's Mourning" and "Lamentations of Jeremiah Johnson," her insight into the unconscious humor of negro whims and eccentricities; "Jessekiah's Brown's Courtship," her knowledge of negro conceit and general sporting proclivities; "Holly and Pizen," her understanding of negro credulity.

These are but a few of her intensely real pictures of negro character. It is enough to say of her work in general that she treated the negro chiefly in the humorous aspect of his home and social relations, and that in these simple and natural pictures the pectliarities of language and mental attitude are always faithfully presented. Since the subleties of dialect cannot all be conveyed through spelling, the full effect of Mrs. Stuart's stories has been best appreciated in her public readings throughout the country.

In all the stories of negro life that have been discussed, some peculiarly humorous or pathetic feature of negro character has always formed the basis of the work. In other words, the negro has always been presented on the side of his eccentricities. 
In the negro of modern times, these eccentricities have grown less and less marked. Large masses of negroes have joined the ranks of the substantial citizen class, or lead quiet, contented lives, little marked by the picturesque features that have usually appeared in fiction. This phase of negro life has not yet been treated in fiction. When it is presented, it will probably be by one of his own race. The beginning of this work has already been made by Paul Lawrence Dunbar, whose short stories will be found in the chronological list at the end of this work. 


\section{CHAPTER IX}

\section{The Mountaineer Story}

In the previous discussion of the ante-bellum sketch writers, it has been noted that burlesque pictures of Tennessee mountaineers were given in George W. Harris's "Sut Lovingwood's Yarns" 1 and other newspaper stories. These, however, contained no accurate character portrayal and preserve no exact local coloring. We have been able to discover only three instances prior to Miss Murfree's work of short stories dealing with any section of the Southern Appalachians. The first of these is John B. Lamar's "Blacksmith of the Mountain Pass," a tale of the North Carolina mountains; second, John Esten Cooke's "Peoney" (Southern Literary Messenger, January, 1852), a story of a little destitute girl of the Blue Ridge in Virginia; and lastly, Frances Hodgson Burnett's "Lodusky" (Scribner's Monthly, September, 1877), a story of the North Carolina mountains.

Miss Murfree ("Charles Egbert Craddock") began her acquaintance with the mountain people, as is well known, when her family were refugeeing during the Civil War in the mountains near Beersheba, Tennessee. ${ }^{2}$ For fifteen years she spent the summer months at this region, and in this way she learned to know by intimate contact the people whom she has so vividly portrayed. A stroke of paralysis in childhood had early confined her to the companionship of books, and this guided her toward a writer's career. Before 1876 she had made contributions to Appleton's Joumal and when that periodical ceased in 1876, two of her stories were left over. One of these "Taking the Blue Ribbon at the Fair"3 appeared in Appleton's Summer Book in 1880. Her reputation as a writer began with "The Dancing Party in Harrison's Cove" published in the Atlantic Monthly for May, 1878. "In the Tennessee Mountains," her

1. Page 40,

2. Rutherford, p. 511.

3. Baskervill: Southern Writers, Vol. I, p. 369. 
first volume of short stories, appeared in 1884 . This volume contains her most characteristic work in the short story. Her later collections of stories, "The Bushwackers and Other Stories" (1895) and "The Young Mountaineers" (1897), contain many stories for juvenile readers and show less strength and depth of feeling. In many of these later tales the moral point attracts too much attention.

As the literary discoverer of the Tennessee mountaineer, Miss Murfree has faithfully depicted the stern, wild, pathetic life of this seclucled region, with its solemn background of mountain and forest. With clearness and masculine force she has delineated the characters of the mountain people and drawn in bold lines the setting for their actions. The tendency shown in her novels to overdo her landscape pictures is naturally not noticeable in her short stories. In these the setting is a particularly strong feature. The descriptions of natural scenery ustually intensify the mood of the story. It would be difficult to find a more effective combination of incidents and setting than that presented in "A-Playin' of Old Sledge at the Settlement," as the gamblers play upon the wicker basket by the light of the pineknot fire while the moonlight wraps the forest in solemn beauty and the mysterious echoes of the rucle laughter are borne back from the mountain sides. Again, how fittingly the scenery of "Lost Creek" harmonizes with the feelings of Cynthia Ware. "The Star in the Valley" and "The Romance of Sunrise Rock" also illustrate her effective use of scenery. For general setting "The Dancing Party at Harrison's Cove" is an excellent example of Miss Murfree's skill.

In the structure of her plots, Miss Murfree does not always show a skill quite equal to her power in drawing setting and character. Occasionally she misses the opportunity for effective climax. This may be observed in "Drifting Down Lost Creek" and "The Haunt that Walks Chilhowee" where the impression, the single effect of the story, is weakened by a few moralizing sentences in the conclusion.

In Miss Murfree's use of the mountaineer dialect, the only fault that may be noted is that it is perhaps too consistent. It has been shown by writers who have visited this region for the purpose of special study that words and phrases really caught 
from other sections have been put into the mouths of these people; that the vocabulary assigned to them is a little too limited; and that the mountaineers have sometimes been amused to hear of the words they were made to use. 4

Miss Murfree's later volumes, as has already been mentioned, did not contain stories of so high literary quality as those of her first volume "In the Tennessee Mountains." The plots are a little more unusual, there is more of strange adventure, but there is less depth of sentiment and feeling and less excellence of style.

\section{SHERWOOD BONNER}

The only other writer of short stories who has made use of the mountain people of Tennessee has been Sherwood Bonner. In 1880 she spent a short time in this region, and thus obtained the material for two of her stories, "The Case of Eliza Bleylock" and "Lame Jerry." Both of these tales are tragedies of humble lives, told with much force.

\section{JOHIN FOX, JR.}

What Miss Murfree has clone for the Tennessee mountaineer in the Great Smokies, the Bald and Chilhowee ranges, John Fox, Jr., has done for the Kentucky people of the Cumberland mountains. Although $\mathrm{Mr}$. Fox is a native of the blue grass region, he has lived for many years close to the natives of the mountains. At the beginning of the financial boom in southwestern Virginia in the early nineties, he went to Big Stone Gap and there soon became active among those who were endeavoring to bring peace and order to this lawless region. His experiences at this period have been partly described in some of the chapters of his "Blue Grass and Rlododendron." "Civilizing the Cumberland," one of the chapters in question, tells how a band of young men who had moved hither to enter business, chiefly Virginians and Blue Grass Kentuckians, most of them

4. On this point, see "Southern Dialect in Life and Literature." By Chas. Foster Smith. South. Biv., Nov., 1885. On the mountain life and customs, see also, "Moonshine Men," by Young E. Allison. South. Biv., Feb., 1887. "Southern Mountaineers." By Wm. G. Frost, Review of Reviews, Mar., 1900. "The Southern Mountaineer," by John Fox, Jr., Scribners, April, 1901. 
college graduates, representing Harvard, Yale, Princeton, the University of Virginia, and other Southern colleges, formed themselves into a voluntee: police guard, each man arming himself with a "Winchester, a revolver, a billy, a belt, a badge and a whistle-a most important detail of the accoutrement, since it was used to call for help. These young fellows guarded the streets, day and night, when there was need; they made arrests, chased and searched for criminals, guarcled jails against mobs, cracked toughs over the head with billies, lugged them to the 'calaboose' and appeared as witnesses against them in court next morning."

Under this wholesome system of discipline, the town became one of the most orderly in the Union. By means of this experience and frequent expeditions through the mountains, Mr. Fox learned to know the Cumberland mountaineer. His stories that fall within the period covered by the present work are found in the volume "Hell-for-Sartain, and Other Stories." These stories show a marked contrast in general method to Miss Murfree's pictures of the Ternessee mountaineer. Instead of the more leisurely narrative abounding in descriptive passages and somewhat lengthy conversations, they are rapid, concise and highly graphic renderings of very simple incidents. Frequently the tale is told in the words of a mountaineer, who through his peculiarities of speech and general spirit gives the needed local color and thus dispenses with the necessity for the more elaborate setting to be found usually in Miss Murfree's stories.

The plots of these stories are almost baldly simple. The incidents are drawn from the ordinary occurrences of mountain life, but there is remarkable force in the telling. With dash and vigor they move directly to the end, unencumbered by unnecessary cletail. It would perhaps be difficult to find in American literature a short story more vivid, concise and rapid than "On Hell-for-Sartain Creek." It is the typical modern short story method used in very brief compass. The last story of the volume "A Purple Rhododendron" is slightly more elaborated than the others, and its pitiable tragedy is drawn with true power. In all these stories, Poe's principles of economy of details and totality of effect are carefully observed. 


\section{OTHER WRITERS OF MOUNTAINEER S'TORIES}

Other parts of the mountain region of the South have been presented in the short stories of various writers. Mary G. McClelland, whose novel "Oblivion" dealt with the North Carolina mountaineers, has written one short story of the Virginia Blue Ridge, "The Tragedy of Humpback" (Harper's, April, 1890). Maurice Thompson has portrayed the mountaineer of Alabama in such stories as "Hodson's Hide Out" (Contury, March, 1885), the same year in which appeared Miss Murfree's "Way Down in Lonesome Cove" in the December Harper.

The mountain region of northern Georgia has been employed as a field by several writers. Joel Chandler Harris, not long after his first success with the plantation legends, turned to this region for the setting of some of his stories. "At Teague Poteat's" (Century, May, 1883), "Trouble on Lost Mountain" (Century, June, 1886), and "A Conscript's Christmas" (Century, December, 1890) shows that Mr. Harris's range was not limited to the telling of negro folk tales.

In "An Idyl of Sinkin' Mountain" Mr. I-. S. Edwards has portrayed the same regiori, using for his setting a locality in Rabun County, near Tallulah Falls.

The mountains of Northern Georgia are also made the scene of several of Mr. William N. Harben's "Northern Georgia Sketches." "The Convict's Return" furnishes a homely but vivid picture of manners in this section.

Another writer who has well presented this region in short stories is Matt Crim. Her volume entitled "In Beaver Cove and Elsewhere" contains, among stories of the "Cracker" and the planter of upper Georgia, several excellent stories of the mountaineers. The title story is a companion picture to "The Dancing Party in Harrison's Cove," picturing as it does the occasional gaiety and the lawlessness of the mountain society.

Most of these stories are founded upon incidents connected with the practices of "moonshiners," the raiding of illicit distilleries, and the mountain feuds. Perhaps the strongest of the stories is "Zekiel." The hero, in order to shield a guilty brother, serves a lengthy term of imprisonment. Since the disclosure of this fact is not made until the end, the story furnishes 
a good illustration of the author's skill in the handling of plot. As a rule the setting of these stories is carefully executed. Landscape pictures are not over elaborated, yet in all the descriptions the reader feels that the true note has been struck to accord with the situation and mood of the actors in the story. The characters throughout are clearly and forcibly drawn. The average type of mountain woman is well described, with her lean and sallow countenance, her sad, faded eyes; quiet, illiterate, but contented with her homespun dress, her two-roomed cabin and her bean-bags.

These stories have one general purpose in common with all the other tales of mountain life that have been described-to bring to view something of the finer spirit that dwells in the lowly inhabitants of the lonely mountain recesses in spite of their ignorance and backward civilization. In one striking particular, Miss Murfree and Miss Crim lave excelled all other Southern writers who have portrayed the life of the mountaineer. They have succeeded in investirg their stories more fully with the spirit of the mountains, and in blending this spirit subtly with the incidents and with the feelings and sentiments of their characters. 


\section{CHAPTER X}

\section{The General, Field}

The general divisions under which the short story has been considered in the last few chapters have represented the more striking classes of stories that have belonged to the South. The material to be treated in the present chapter will not permit in most cases of similar grouping. Many distinct fields have been occupied by different writers, who must, in consequence, be considered rather individually than as a member of a group. Some writers will of necessity be mentioned whose work does not belong exclusively to the South. Southerners by birth and residence, they have transferred themselves to other parts of the country, and have ceased to treat Southern themes. On the other hand, a few writers born outside of the South have, during a part of their lives, been closely identified with Southern life and have portrayed it in their stories. In all such cases reference will be made only to that part of an author's work which on these grounds may be classed as Southern. The mere fact of residence is not always a sufficient reason for identifying an author with a particular section. Accordingly, a writer like Frances Hodgson Burnett can be included in a work of this sort only by virtue of her few stories that were directly the product of her life in the South. Born in England, she happened, on first coming to America, to reside for ten years (18651875 ) in Tennessee. Here she began her literary career, but her stories were almost entirely of English life. "Lodusky," a tale of the North Carolina mountains, is one of her few stories that directly portray Southern life.

It may also be stated, by way of introduction, that in some cases it will be necessary to mention writers whose work has been partly treated in the previous chapter's.

We have already taken some account of the Civil War as a factor in the development of the Southern short story. Several fields of Southern fiction were distinctly opened by the events and consequences of this period. Among these are the stories 
of negro dialect and character, the pictures of the ante-bellum South, the stories of the war and its after effects. These, taken together, form an important part of the later Southern short story material.

Foremost among the writers who entered this general field was Thomas Nelson Page. His early negro dialect stories, which also involved his presentation of the Old South and some incidents of the war period, have already been discussed. His later work belongs under four heads: stories founded upon the Civil War; humorous stories, chiefly reminiscences or partial suggestions from his experience in the practice of law and the associations into which it led him; stories of social life; and stories with foreign settings. In such war tales as "The Burial of the Guns" and "Little Darby," Mr. Page maintained the high standard set in his early work. Most of his stories connected with court life are work of much lighter value; They are only lawyers' anecdotes well told. They belong among the short. light pieces which he contributed to the "Editor's Drawer" department of Harper's Magazine in 1893 and 1894. Among his tales of social life "Miss Dangerlie's Roses" is the most forcible. In "Elsket" Mr. Page showed his ability to handle a short story of more than sectional interest. After his first volume it is his strongest piece of work in the short story.

Another writer who chose the field of the Old South and the Civil War period was Constance Cary Harrison (Mrs. William Burton Harrison). In "Crow's Nest" and "Una and King David" she gave two pictures of the war period similar in type to Mr. Page's work. The first of these followed "Marse Chan" by little more than a year. Coming at the time when the Southern war story was at the beginning of its popularity, its tragic pathos and well drawn background of Southern life made it one of the most successful stories of its type. In "Bellhaven Tales," published in the same volume with the two stories just mentioned, the gentle, high-bred life of old Virginia is described in a few simple tales having their setting in Alexandria. In this quiet Virginia town, first named Bellhaven, "might have been perceived," says Mrs. Harrison, "just before the outbreak of the war between the States, a faint flavor of early colonial days 
lingering like the scent of rose-leaves in an old-time china jar." It is this flavor which the author successfully reproduces in "Bellhaven Tales."

As reminiscences of the Civil War the "Southern Solilier Stories" of George Cary Eggleston may be mentioned at this point. As early as $1874, \mathrm{Mr}$. Eggleston had published his "A Rebel's Recollections." He had served in Company G, First Virginia Cavalry, during the four years of the war, partly in the capacity as clerk to General J. E. B. Stuart, and a part of the time as Sergeant Major.2 These stories are not dry history, but incidents of true interest, told with the ease of a skilled raconteur.

The changed conditions of Southern life after the Civil War, the contrast between the new and the old, was one of the early motives in the work of Frances Courtenay Baylor (Mrs. George S. Barnum). "In the Old Dominion" (Atlantic Monthly, August, 1883), one of the most popular of her early stories, gives well the typical Virginia background. For many years she continued to be one of the most frequent contributors to magazines among the writers of the short story in the South.

It is natural that the short story should be largely local in its choice of material. Its fitness for conveying a single vivid inpression of provincial types makes it an admirable expression of life and character in a limited section. This feature of localism has been a marked characteristic of the Southern short story.

Among those who have encleavored to express the genius of a particular section, none has shown in his stories a finer quality of literary workmanship than James Lane Allen. Mr. Allen's subject matter has been the romance of Kentucky life. $\mathrm{He}$ called some of his early stories romances, and such they are in spirit and in form. His short stories had their setting chiefly in Kentucky history of the past. Instead of portraying his section throngh ordinary local types, with the aid of dialect and the usual methods of the local color artist, he has succeeded in lifting his characters above the realm of the commonplace, and has

1. Bellhaven Tales, p. 1.

2. See Library of Southern Literature, Vol. IV, p. 1526. 
saturated his narratives with the spirit of romance. At the time that his short stories were written, the process in his literary development by which the romanticist has been gradually supplanted by the realist had not yet begun.

In the introductory sketch to "Flute and Violin and Other Kentucky Tales" he has explained how small a part of his material was drawn directly from actual persons and incidents. "King Solomon of Kentucky" is the only one of the stories founded directly upon facts. The Reverend James Moore and Peter Cotton were historical personages, but the manner in which these characters were employed had no foundation in fact. The tales of "The White Cowl" and "Sister Dolorosa" were entircly icleal save for their setting. The use which Mr. Allen made of the abbey of the Trappist Monks and the Convent of the Stricken Heart involved him in some controversy with the Catholic newspapers of the country, which criticized him on the supposition that he was detailing actual incidents. ${ }^{3}$

The most striking qualities of Mr. Allen's short stories are the felicitous descriptions of persons and natural scenery, the delicate humor and tender pathos of his scenes, the exquisite grace of his style, and the subtile, romantic quality that pervades the whole. He was manifestly conscious in his art; for few writers have been more scrupulously careful in the revision of their work. He accomplisted nothing new in plot construction, but he brotight to the short story a beauty of style and an artistic finish that have scarcely been excelled in the recent history of this type of fiction. In "The White Cowl" and "Sister Dolorosa" the situations were somewhat novel for American short stories, and the public was surprised and delighted at the discovery of these old world motives in the setting of the new. In these stories, however, the element of perfect naturalness seems to be sacrificed at times to the demands of romance. The charm of these stories lies in the pathos of the situations and the delicate revelation of the inner life and feeling of the characters.

For graceful simplicity and true human quality, the initial story, "Flute and Violin," may justly be regarded as the master-

3. For Mr. Allen's answer to these criticisms, see "Century," May, 1891. 
piece of the collection. How slight is the framework of the story, and yet how firmly its pathos grips the leart! The author's refined humor and sympathetic view of human nature are seen to full advantage in the picture of the parson, an inimitable piece of personal description. Barring the absence of descriptions of scenery, this tale furnishes a true measure of Mr. Allen's power in the short story.

During the two years inmediately preceding the appearance of Mr. Allen's stories in the Century, another writer, romantic in tendency, but differing in quality, was achieving popularity in an entirely different field. Amélie Rives passed at one step into notoriety by the writing of her first short story, "A Brother to Dragons" (Atlantic Monthly, March, 1886). After an interval of a little more than a year came "The Farrier Lass O'Piping Pebworth" (Lippincott's, July, 1887) ; "Nurse Crumpet Tells the Story," (Harpcr, September, 1887); "The Story of Arnon," (Harper, November, 1887); and "Inja" (Harper, December, 1887). The first three have a setting of sixteenth and seventeenth century English life. The next tells a tale of Amon, the fifth son of Noah.

The field of her work in these early tales seems, at first thought, a strange one for a Virginia girl reared in the country. But when we recall her irregular edlucation, her browsing tendency in literature, and her extensive reading, her seclucled life, her beautiful surroundings, slightly suggestive of English rural life, her distingtished ancestry, and her notable talent for art, it does not seem difficult to explain the romantic atmosphere which her imagination created.

There is power in these tales, but there is crudeness as well. In her reproduction of the language and manner of thought of the remote periods she described, she showed strength of imagination and a distinct gift of phrasing, but the style is unpruned, and runs too often into unrestrained luxuriance. In these stories, moreover, the interest rests on incident rather than on the interpretation of character. The world in which the author moved was one too remotely ideal to admit of delicate analysis of feeling. Only the emotions that are elemental are presented, and the incidents are usually of a conventional type. When all 
has been said, however, the author of these vigorous romantic tales has to be credited with literary talent. The strange remote settings and antique language do not account entirely for their popularity.

The work of Amélie Rives in the short story was somewhat apart from the main current of Southern literature. The writers of this section have found their true and natural expression in the delineation of phases of provincial life that came directly under their notice.

Among the Southern short story writers of the last decade of the nineteenth century none surpassed Mrs. Ruth McEnery Stuart in the naturalness and interest of her work. Her negro stories have already been discussed. Apart from her few stories of the Latin American in New Orleans, the rest of her material was drawn from the life of the simple country folk and villagers of the South, particularly the Arkansas people among whom she lived for a time. Her "Simpkinsville," if not indicated on the map, is a place none the less distinct and familiar in the minds of her readers. All her stories are delightfully humoroussometimes pathetic-studies of character. The framework of incident and setting is always simplified to bring out distinctly the human picture. Her characters quaintly express themselves through their own utterances in a manner that shows the author's penetrative insight and complete identification of feeling with that of the persons she describes. Among her many excellent stories, such tales as "The Woman's Exchange in Simpkinsville," "The Unlived Life of Mary Ellen," "The Note of Scarlet," "A Slender Romance," and "Sonny" stand out as prominent illustrations of her chief excellencies.

In his ncvelettes, "Colonel Carter of Cartersville" and "Colonel Carter's Christmas," Francis Hopkinson Smith described Southern characters. His short stories have chiefly treated other fields. Only three appear to have their setting in the South: "A Kentucky Cinderella," (Ladies' Home Journal, December, 1898); "Six Hours in Squantico," (Harper, June, 1890); and "Never Had No Sleep," (Harper, October 1894). Only the first is really a picture of Southern life. The other 
two bclong to the anecdote type, and happen to be connected with journeys in Virginia.

After the most striking types of character peculiar to the South had been presented in fiction, the discussion of some of the South's problems found its way into the short story. Sarah Barnwell Elliott, of Sewanee, Tennessee, in several of her stories was a writer with a purpose. In "An Incident" (Harper, February, 1898), and "Squire Kayley's Conclusions," (Scribner, December, 1897), she set forth certain views in regard to the question of lynching that attracted wide attention. These stories were issued in the volume entitled "An Incident and Other Happenings," (1899). The other stories of the volume were "Miss Maria's Revival" (Harper, August, 1896), "Faith and Faithfulness" (Harper, October, 1896); "An Ex-Brigadier," "Without the Courts," "Mrs. Gollyhaw's Candy-Stew," and "Baldy," (Harper, February, 1898).

Mary Applewhite Bacon, of Marietta, Georgia, has written, in addition to negro dialect tales, many stories introducing the life of the Southern mill people.

Toward the close of the century, Southern writers in some cases began to use scenes outsicle of the South as the setting for their stories. This has already been noted in the case of Thomas Nelson Page. The tale of society life is well illustrated in the short stories of Julia Magruder's volume, "Miss Ayr of Virginia and Other Stories," (1896). Miss Magruder, a native of Charlottesville, Virginia, spent her early life there. Later she passed some years in the house of her sister in North Carolina, and finally made her home in Washington, D. C., from which she went on frequent visits to England.

In the first story of her collection, an interesting picture is given of the Southern girl in New York society. The motif of the story is the contrast between refined simplicity and true sentiment, on the one hand, and the shams of wealtin and fashion on the other. In "A New Thing under the Sun," the divorce question is presented in a somewhat novel manner, leaving the reader with the feeling that the man in the case is a brute and the woman a psychologica! puzzle, but the air of reality is en- 
tirely preserved and the effect of the story well attained. The rest of the stories, which all deal with the sentiment of love, present interesting situations combined with thoroughly true and wholesome portrayal of human feeling.

Among other writers of short stories near the close of the century may be mentioned Waitman Barbe of West Virginia, Samuel Minturn Peck of Alabama, Armistead Churchill Gordon of Virginia, Mrs. Mary Moore Davis of Louisiana, and others mentioned in the list of writers given on pages of this work.

Mr. Barbe, born in Monongalia County, West Virginia, in 1864, began his literary work as managing editor of the Daily State Joumal of Parkersburg, and is at present assistant to the president of the University of West Virginia at Morgantown.4 In 1896, he published a volume of short stories entitled "In the Virginias." "The preacher of the Three Churches" is perhaps the finest story of the collection.

Samuel Minturn Peck of Tuscaloosa, Alabama, well known as a poet, showed his ability to write excellent short stories in his "Oakville Stories," which appeared in the (Boston) Illustrated Anerican, Leslic's Weekly, the New York Independent, and The Outlook. In these tales he described Tuscaloosa under the name of "Oakville."

Mr. Armistead C. Gordon's volume of short stories was entitled "Envion and Other Tales of Old and New Virginia." His general field was somewhat similar to that of Mr. Page.

Mrs. Davis of New Orleans, born in Talladega, Alabama, has spent her life, also, partly in Texas and partly in Louisiana, and has well presented the life of these two states in her fiction. "An Elephant's Track and Other Stories" (1896) represents her best work in the short story. "The Love Stranche," the most striking story of the collection, has already been mentioned. In the quality. of her art she suggests comparison with the best writers of the modern French short story.

4. Who's Who in America, 1908-'09.

5. Baskervill: Southern Writers, Vol. II, p. 327. 
In the present study of the short story in the South, we have seen the progress from the simple sketch of local manners to the finished short story of characteristic Southern types of life. It has been observed how the principles of the short story most clearly exemplified and expounded by Poe have been, in many cases, embodied in new form in the work of the later Southern writers. It has also been shown that the large majority of the Sonthern short stories, of which Page's work may be taken as the type, show a less rigid technique, a more easy and natural structure. After the achievement of Poe, the mid-century showed as its prevailing type the highly sentimental love tale, tending toward the sensational, conventional in plot and character, and belonging more to the class of the older tale than to the molern short story. The work of the humorous sketch writers was noted a.s the only fresh and original contribution at that period to the growth of the short story in the South. The stimulating effect of the Civil War and its accompanying revolution in Southern life was observed, and the various types of the short story since produced were briefly treated. In the later development of the Southern short story, the progress has been from a treatment of themes entirely local to a discussion of those connected with the wider social life common to the nation at large. 


\section{Short Story Writers of the South}

\section{Nineteenth Century}

Aclamson, Robert L., Georgia.

Allen, James Lane (1849-, born near Lexington, Ky.), New York.

Altsheler, Joseph Alexander (1862- , Three Springs, Ky.), New York.

Anderson, R. H., Richmond, Va.

Andrews, Eliza Frances (1840- , Washington, Ga.), Montgomery, Ala.

Archer, G. W., Maryland.

Autustine, Geo., Louisiana.

Bacon, Mary Applewhite (1863- ). Marietta, Ga.

Bagby, George William (1828-1883, Buckingham Co., Va.), Lynchburg, Va.

Baker, Mrs. Julia Kein Wetherill (1858- , Woodville, Miss.), Louisiana.

Baldwin, Joseph G. (1815-1864, near Winchester), Alaban1a, California.

Barbe, Waitman (1864- , Monongalia Co., W. Va.), Morgantown, W. Va.

Barnett, Evelyn Scott Snead, Louisville, Ky.

Barron, Joseph Day (1833- , Upson Co., Ga.), Montgomery, Ala.

Baylor, Francis Courtenay (Mrs. George S. Barnum) (1844ton, Va.

,Fayetteville, Ark.), Texas, Winchester, Va., Lexing-

Bennett, Mrs. Martha Haines Butt, Norfolk, Va.

Blount, Annie R. (1839- ), Georgia.

Bonner, Katharine Sherwood (Mrs. Edward McDowell) 1849-1883, Holly Springs, Miss.), Boston.

Bonsal, Stephen (1863- , Baltimore, Mi.), New York.

Bowen, Mrs. Sue Petigrt King (1824-1875), Charleston, S. C. 
Boyle, Virginia Frazer (1863- , Chattanooga, Tenn.), Memphis, Tenn.

Bradley, Mrs. Mary E. N. (1834- , Maryland), Virginia. Bradlev, T'. Bibb, Virginia.

Brown, Willian Perry (1847- , Indian Territory), Glenville, W. Va.

Bryan, Ella Howard (Savannah, Ga.), Dalton, Ga.

Bryan, Mrs. Mary Edwards (1844- , Fonda, Fla.), Atlanta, $\mathrm{Ga}$.

Buchanan, A. M. T., Baltimore, Md.

Burke, T. O. A.

Burnett, Frances Hodgson (Mrs. Stephen Townsend) (1849, Manchester, Eng.). Tennessee, Washington.

Cabell, Julia Mayo, Richmond, Va.

Cable, George Washington (1844- , New Orleans, La.), Northampton, Mass.

Campana, Giacomo S., Harrisonburg, Va.

Carter, St. Ledger Lanclon (Nugator), Virginia.

Caruthers, William (1806-1872, Virginia), Georgia.

Chapeaı, Ellen Chazal (1844- ), Charleston, S. C.

Chesney, Esther.

Charlton, Robert M. (1807-1854), Savannah, Ga.

Chopin, Mrs. Kate O'Flaherty (1851-1904, St. Louis, Mo.), New Orleans, La.

Clarke, Mrs. Mary Bayard, 1822-1886, North Carolina.

Cloud, Virginia Woodard, Baltimore, Md.

Cobb, Joseph Beckham (1819-1858, Georgia), Mississippi.

Conway, Moncure D. (1832-1907, Richmond, Va.), England, New York.

Cooke, John Esten (1830-1886), Winchester, Va.

Cooke, Phillip St. George (1809-1895), Virginia.

Cowden, Mrs. V. G. Mobile, Ala.

Crim, Matt., Louisiana, Georgia.

Dargan, Clara V. (1840- , Fairfield District, S. C.), Georgia.

Davis, Mrs. Mary Evelyn Moore (1852- , Talladega, Ala.), Texas, New Orleans.

Deas, Annie S., South Carolina.

Deas, Fannie M. P., Charleston, S. C.

Dimitry, Alex. (1805-1883), Louisiana. 
Dimitry, Chas. (1837- , District of Columbia), Louisiana. Drake, Benjamin (1794-1841), Kentucky, Ohio.

Dromgoole, Will Allen (1860- , Murfreesboro, Tenn.), Estill Springs, Tenn.

Early, Mrs. Mary Washington Cabell (1846- ), Virginia. Easby-Smith, Jas. S. (1870- , Tuscaloosa, Ala.), Washington, D. C.

Easter, Mrs. Margnerite E. (1839-1894. Waterford, Va.), Warren Co., Va., Baltimore.

Edwards, Harry Stillwell (1854- ), Macon, Ga.

Egan, Lavinia Hartwell, Texas, Louisiana.

Eggleston, George Cary (1839- , Vevay, Ind.), Virginia, New York.

Ellicott, John Morris (1859- ，St. Inigoes, Mi.), Washington, D. C.

Ellijay, Louise, Virginia.

Elliott, Sarah Barnwell (1850- , Savannah, Ga.), Sewanee, Tenn.

Elliott, Wm. (1788-1863), Beaufort, S. C.

Ewell, Alice Maud, Virginia.

Fairman, Henry Clay (1847- ), Georgia.

Fetter, George S., Louisville, Ky.

Field, Joseph M. (1810-1856), England, Missouri, Alabama.

Fox, John, Jr. (1863- , Bourbon, Ky.), Virginia, New York.

Fremont, Mrs. Jessie Benton (1824-1902, Virginia), Missouri, California.

Garden, Alex. (1757-1829), Charleston, S. C.

Gardner, Helen Hamilton (Mrs. Smart, Mrs. S. A. Day) (Winchester, Va.), New York.

Gay, Mary A. H., Georgia.

Gibbs, George (1870- ), New Orleans.

Gilman, Carolina Howard (1794-1888, Massachusetts), South Carolina.

Glasgow, Ellen (1874- ), Richmond, Va.

Gordon, Armistead Churchill (1855- , Albemarle Co., Va.), Staunton, Va.

Gregory, E. S., Virginia. 
Hale, Will Thomas (1857- , Liberty, Tenn.), Nashville, Tenn.

Halleck, Reuben P. (1859- ， Rock Point, L. I.), Louisville, $\mathrm{Ky}$.

Hampton, Mrs. Kate Phelan (Mrs. Wade Hampton, Jr.), South Carolina.

Hancock, Mrs. S. J., Kentucky.

Harben, William N. (1858- , Dalton, Ga.), New York.

Harland, Marion (see Mrs. Terhune).

Harris, George W. (1814-1869), Tennessee.

Harris, Joel Chandler (1848-1909, Eatonton, Ga.), Savannah, Atlanta.

Harris, Julien G.

Harrison, Constance Cary (Mrs. William Burton Harrison) (1846- , Fairfax Co., Va.), New York.

Heath, James E. (1812-1880), Richmond, Va.

Henry, Mrs. Ina M. Porter, Alabama.

Hentz, Mrs. Carolina Lee Whitney (1800-1856, Massachusetts), North Carolina, Alabama, Florida.

Hempsteacl, Junius L., Lotisiana.

Holmes, Isaac Edward (1796-1876), South Carolina.

Holmes, Mary Jane, Massachusetts, Kentucky.

Hooper, Johnson (1815-1863, Wilmington, N. C.), Alabama.

Hooper, Sue E., Virginia.

Hulse, Georgiana A. (after 1853 Mrs. McLeod) (1835-1890, Florida), Maryland.

Hungerford, Mrs. Betty Keyes. (?)

Hutson, Woodard, Maryland.

Ingraham, Joseph Holt (1809-1860), Maine, Mississippi.

Ingraham, Prentiss (1843- ?), Mississippi.

Jack, W. C., Georgia.

Jett, James, Virginia.

Johnston, Richard Malcolm (1822-1898, Hancock Co., Ga.),

Baltimore, Md., Washington, D. C.

Jones, Charles Colcock, Jr. (1831-1893, Summerville, Ga.),

Savannah, Ga.

Jones, Hamilton C.

Kennedy, John Pendleton (1795-1870), Baltimore, Md.

Kennedy, Sarah Beatumont (Somerville, Tenn.), Memphis. 
King, Grace Elizabeth (1852- ), New Orleans.

Kinkead, Eleanor Talbot.

Ladd, Mrs. Catharine Stratton (1809- ，Virginia), South Carolina.

Lamar, John Basil (1819-1862, Milledgeville, Ga.), Macon, Ga. Langborough, Mrs. Mary Webster (1836-1887), Arkansas.

Langhorne, Orra Gray, Virginia.

Lanier; Clifford Anderson (1844- , Georgia), Alabama.

Lathrop, Elise (Translator of Stories), Sumpter, S. C.

Lee, Mary Elizabeth (1813-1845), South Carolina.

Legaré, James Matthews (1823-1859), South Carolina.

Longstreet, Augustus Baldwin (1790-1870, Augusta, Ga.), Louisiana, South Caroliria, Mississippi.

Lucey, Thomas Elmore (1874- , North Carolina), Arkansas. Lynde, Francis (1856- , Lewiston, N. Y.), Chattanooga, Tenn.

Magruder, Julia (1854-1907, Charlottesville, Va.), North Carolina, Washington, District of Columbia.

Marsdale, Caroline.

Martin, George Madden (Mrs. Atwood R. Martin) (1866- ）, Louisville, Ky.

Mayer, Dr., South Carolina.

McCabe, James D. (1842-1888), Richmond, Va.

McClelland, Mary G. (1853-1895, Norwood, Va.), Buckingham County, Va.

McGill, Mary Tucker, 1832-1899.

McGowan, Alice (1858- , Perrysburg, O.), Nashville, Tenn.

McIntosh, Maria Jane (1803-1878, Georgia), New Jersey.

McKinney, Annie Valentine Booth (Warren County, Mississippi), Knoxville, Tenn.

McKinney, Kate Slaughter (1857- , London, Ky.), Montgomery, Ala.

Means, Celina E., South Carolina.

Meekins, Lynn Roby (1862- ), Baltimore, Md.

Meriwether, Lee (1862- , Columbia, Miss.), St. Louis, Mo.

Miles, George Henry (1824-1871), Maryland.

Milwaril, Mrs. Maria G., Georgia.

Minor, Virginia Otey (Mrs. B. B. Minor) (1822-1900), Richmond, Va. 
Moore, Idora McClellan (Mrs. Plowman, Mrs. Moore) (1843), Talladega, Ala.

Moore, John Trotwood (1858- ), Alabama, Tennessee.

Mosby, Ella F. (1846- ), Virginia.

Murfree, Fannie D., Murfreesboro, Tenn.

Murfree, Mary Noailles (1850- ), Murfreesboro, Tenn.

Page, Roswell (1858- ), Hanover Co., Va.

Page, Thomas Nelson (1853- , Hanover Co., Va.), Richmond, Va.; Washington, D. C.

Palmer, John William (1825-1906), Baitimore, Md.

Peck, Samuel Minturn (1854- ), Tuscalloa, Ala.

Peck, William Henry (1830-1892), Augusta, Fla.

Pendleton, Louis B. (1861- , Tebeauville (Now Waycross, Ga.), Macon, Ga.

Peters, Mrs. M. Sheffey (Marion, Va.), University of Virginia.

Pickett, Mrs. LaSalle Corbell (1848- , Chuckatuck, Va.), Washington, D. C.

Pittman, Hannah Davis (1840- , Kentucky), St. Louis, Mo.

Pleasants, Mary W., Virginia.

Poe, Edgar Allan (1809-1849, Boston, Mass.), Richmond, Va., Philadelphia, New York.

Pool, Bettie F., North Carolina.

Preston, Margaret Junkin (1825-1899, Philadelphia), Lexington, Va.

Preston, William Campbell (1794-1860), South Carolina.

Read, Opie P. (1852- , Nashville, Tenn.), Arkansas, Kentucky, Illinois.

"Reid Christian" (see Tiernan, Mrs. Frances Fisher).

Richardson, Norval (1877- ), Vicksburg, Miss.

Rives, Amélie (see Troubetzkoy, Princess Amélie) (1863- , Richmond, Va.), Albemarle County, Va.

Roach, Mrs. Abby Meguire (Philadelphia), Louisville, Ky. (Wrote short stories as Abby Swain Meguire.)

Robertson, Harrison (1856- , Murfreesboro, Tenn.), Louisville, Ky.

Robb, John S.

Rosebro, Viola (Pulaski, Tenn.), New York. 
Schele de Vere, Maxamilian (1820-1898, Wexio, Sweden), University of Virginia; Washington, D. C.

Scott, Sutton Selwyn (1830- Huntsville, Ala.), Auburn, Ala.

Seawell, Mollie Elliott (1860- Gloncester County, Va.), Washington, D. C.

"Shepperd, Eli." (See Young, Martha.)

Shields, S. J. (1856- , Murfreesboro, Tenn.), Louisville, Ky.

Shortridge, Mrs. Belle Hunt (1858-1893), Texas.

Simms, William Gilmore (1806-1870, Charleston, S. C.), Barnwell, S. C.

Siviter, Mrs. Anna Pierpont (Fairmont, Va.), Pennsylvania.

Smith, Francis Hopkinson (1838- ), Baltimore, Md.

Southworth, Emma D. E. N. (1819-1899), District of Columbia.

Spencer, Eclward (1834 ), Maryland.

Sprunt, James (1846- ), Scotland, N. C.

Stabler, Jennie L. ("Jennie Woodville"), Lynchburg, Va.

Stuart, J. A., Charleston, S. C.

Stuart, Mrs. Ruth McEnery (1856- , Avoyelle Parish, La.), New Orleans, Arkansas, New York.

Sweet, Alexander Edwin (1841-1901), Texas.

Taylor, George Boardman (1832-1907, Virginia), Maryland.

Terhune, Mrs. Mary Virginia (Marion Harland) (1831Amelia County, Va.), Richmond, Va., Pompton, N. J.

Thomas, Frederick William (1811-1866, South Carolina), Maryland, Alabama.

Thompson, James Maurice (1844-1901, Fairfield, Ind.), Missouri, Kentucky, Georgia, Indiana.

Thompson, William Tappan (1812-1882, Ravenna, O.), Augusta, Ga., Savannah, Ga.

Thorpe, Thomas Bangs (1815-1878, Massachusetts), Louisiana, New York.

Tiernan, Mrs. Frances Fisher ("Christian Reid") (1846, Salisbury, N. C.). Baltimore, New York.

Walker, Stusan ("Nasus"), Fredericksburg, Va.

Waltz, Elizabeth Cheney (1866-1903), Ohio, Ky. 
Walworth, Mrs. Jeannette Ritchie (1837- , Mississippi), Louisiana.

Warfield, Mrs. Catharine Anne (Natchez, Miss.), Kentucky. Waring, Mrs. Malvinia S. (1842- , Newberry, S. C.), Columbia, S. C.

Watkins, Tobias (Pertinax Particular) (1780-1855), Maryland. Webber, Chas. Wilkins (1819-1856), Kentucky.

Weiss, Mrs. S. A.

Whitlock, Louise Clarkson (1865- ), Baltimore.

Whittlesay, Sarah Johnson Cogswell (1825- , North Carolina), Virginia.

Wilcox, Marion (1858- ), Georgia.

Wiley, Calvin Henderson (1819-1887), North Carolina.

Williams, Mrs. Mary Bushnell (1826- ), Louisiana.

Williams, Mrs. Martha McCulloch (Montgomery County, Tenn.), New York.

Wincle, Mrs. Mary Jane (1825- ，Delaware), Washington, D. C.

Winston, Annie Steger, Richmond, Va.

Woods, Mrs. Catharine Pearson (1853- , Wheeling, W. Va.), Baltimore, Md.

Worthington, Mrs. Jane Taylor Lomax ( -1847), Virginia.

Young, Martha ("Eli Shepperd"), Greensborough, Ala. 


\section{Periodicals Containing Short Stories by Southern Writers}

The following periodicals are referred to in the chronological list of short stories:

Appleton's Summer Book.

Burton's Gentleman's Magazine.

Fetter's Southern Magazine.

Godey's Lady's Book.

Graham's Magazine.

Harper's Magazine.

Lippincott's Magazine.

McClure's Magazine.

Russell's Magazine.

Sartain's Union Magazine.

Scribner's Monthly (Now Century Magazine).

Scribner's Magazine.

The American Museum.

The American Whig Review.

The Atlantic Monthly.

The Baltimore Monument.

The Baltimore Saturday Visitor.

The Catholic Mirror.

The Century Magazine.

The Columbian Magazine.

The Cosnopolitan.

The Knickerbocker Magazine.

The Laclies' Home Journal.

The Land We Love.

The Literary and Evangelical Magazine.

The Magnolia Magazine.

The Magnolia or Southern Appalachian.

The New Eclectic.

The Outlook.

The Philadelphia Dollar Newspaper.

The Philadelphia Saturday Chronicle, and Mirror of the Times 
The Philadelphia Saturday Evening Post.

The Philadelphia United States Post.

The Pioneer.

The South Atlantic.

The Southern Bivouac.

The Southern Field and Fireside.

The Southern Home Journal.

The Southern Literary Journal.

The Southern Literary Messenger.

The Southern Magazine.

The Southern Rose.

The Southern and Western Monthly Magazine and Review.

The South-Western Monthly.

The Spirit of the Times (New York). 


\section{Chronological List of Southern Short Stories Written in the Nineteenth Century}

For works marked with asterisk, (") see Johnson's "Southern Fiction Prior to $1860 . "$

\section{1}

Anonymous: Warning, a Tale. The Lit. and Evang. Mag., Richmond, Va.

*Watson, Tobias (Pertinax Particular): Tales of the Tripod; or a Delphian Evening. Baltimore.

1822

Garden, Alexander: Anecdotes of the Revolution.

*Holmes, I. E.: Recreations of George Telltale (a collection of stories, essays and descriptive sketches).

$$
1824
$$

Anonymous: Tales of an American Landlord. Containing Sketches of Life South of the Potomac. See Evang. \& Lit. Rev., Dec., 1824.

$$
1827
$$

Anonymous: A Tale for the Times. Lit. \& Evang. Mag., Dec.

*Dimitry, A.: 1830-1835. Many short stories in annuals, under the name of "Tobias Guarnerius."

1832

*Kennedy, J. P.: Swallow Barn. Phil., Carey \& Lea.

$$
1833
$$

Poe, E. A.: Ms. Found in a Bottle. Balto. Sat. Visitor, Oct. 12th.

\section{4}

Carter, St. L. L. ("Nugator") : The Mechanician. So. Lit. Mess., Dec.

Heath, J. A.: Misfortune and Genius. So. Lit. Mess., Oct. 
Anonymous: A Tale of the West. Signed Lovingston, Va., So. Lit. Mess., April.

"E," Henry Co., Va.: The Duel. So. Lit. Mess., July.

Hentz, Mrs. C. L. W.: The Village Pastor's Wife. So. Lit. Mess., Mar.

Longstreet, A. B.: Georgia Scenes. Augusta, Ga.

McCabe, J. C.: Scraps (collection of poems and tales). Published by J. C. Walker, Richmond, Va.

Poe, E. A.: Berenice. So. Lit. Mess., Mar.

Poe, E. A.: Morella. Sc. Lit. Mess., Apr.

Poe, E. A.: Some Passages in the Life of a Lion (Lionizing) So. Lit. Mess., May.

Poe, E. A.: Hans Pfaall. So. Lit. Mess., June.

Poe, E. A.: The Assignation (The Visionary). So. Lit. Mess., July.

Poe, E. A.: Bon-Bon. So. Lit. Mess., Aug.

Poe, E. A.: Shadow, A Parable. So. Lit. Mess., Sept.

Poe, E. A.: Loss of Breath. So. Lit. Mess., Sept.

Poe, E. A.: King Pest. So. Lit. Mess., Sept.

*Thorpe, T. B.: The Big Bear of Arkansas and Other Tales by Various Authors. Edited by William T. Porter.

1836

Poe, E. A.: Metzengerstein. So. Lit. Mess., Jan.

Poe, E. A.: The Duc de L'Omelette. So. Lit. Mess., Feb.

Poe, E. A.: Four Beasts in One; The Homo-Cameleopard. So. Lit. Mess., Mar.

Poe, E. A.: A Tale of Jerusalem. So. Lit. Mess., Apr.

Simms, W. G.: Logeechic; or the Branch of Sweet Water. Magnolia Mag.

*The Spirit Bridegroom. So. Lit. Jour. Vol. 3, pp. 193-209.

1837

Gilman, C.: The Young Conspirator. So. Rose, Sept. 2.

Gilman, C.: Mr. Inklin. So. Rose, Oct. 14.

Gilman, C.: Mr. Niblo. So. Rose, Dec. 23.

*Ingraham, Jos. H.: Spheeksphobia; or The Adventures of Abel Stingflyer, A. M. So. Lit. Mess., Oct. 
Buchanan, Mrs. A. M. F.: A Folly Cured. Balto. Mon., Oct. Cartthers, W.: Climbing the Natural Bridge. Knickerbocker Mag.

*Drake, B.: Tales and Sketches from the Queen City. Cinn. E. Morgan \& Co.

Gilman. C.: The Missionaries. So. Rose, June 6.

Jones, J.: The Artist's Death. Balto. Mon., Dec.

Poe, E. A.: Ligeia. The Amer. Mus., Sept.

Poe, E. A.: How to Write a Blackwood Article. The Amer. Mus., Dec.

Poe, E. A.: A Predicament; or the Scythe of Time. The Amer. Mus., Dec.

*:Simms, W. G.: Carl Werner and Other Tales of Imagination. Published by George Abelard, N. Y.

\section{9}

Anonymous: The Prediction. A Tale of the Hugutenots. By Lacly of Va. So. Lit. Mess., May.

T. H. E., Amelia Co., Va.; My Cousin Helen. So. Lit. Mess, Sept.

Hooper, J. J.: My First and Last Fire Hunt. N. Y. Sp. of Times, Sept. 21.

Ingraham, J. H.: A Legend of the Mountain of Burning Stone. So. Lit. Mess., Dec.

Nilward, Mrs. M. G.: The Bachelor Beset; or The Rival Candiclates. So. Lit. Mess., Nov.

Milward, Mrs. M. G.: Pleasant Range. So. Lit. Mess., May. Pierson, Mrs. L. J.: The Haunted Cliff. Balto. Mon., Sept. Pierson. Mrs. L. J.: The Maid of the Mountain. Balto. Mon., Oct.

Poe, E. A.: The Devil in the Belfry. Phil. Sat. Chron. and Mirror of the Times, May 18.

Poe, E. A.: The Man That Was Used Up. Burton's Gent. Mag., Aug.

1. The dates for Poe's tales, other than those issued in the "Southern Literary Messenger," have been taken from the "Textual Notes for the Tales of Edgar Allan Poc," by R. A. Stuart. 
Poe, E. A.: The Fall of the House of Usher. Burton's Gent. Mag., Sept.

Poe, E. A.: William Wilson. Burton's Gent. Mag., Oct.

Poe, E. A.: Silence (Siope): A Fable. Balto. Bk., 1839.

Poe, E. A.: The Conversation of Eiros and Charmion. Burton's Gent. Mag., Dec.

Worthington, Mrs. J. T.: The Poet. So. Lit. Mess., Mar.

Worthington, J. T.: The Poet's Destiny. So. Lit. Mess., May.

Worthington, Mrs. J. T.: The Missionary. So. Lit. Mess., Sept.

\section{0}

Miss A. M. B., Petersburg, Va.: The Prisoner on Parole. So. Lit. Mess., Apr.

Miss T. H. E., Amelia Co., Va.: Mr. Lindsay's Manuscript. So. Lit. Mess., Mar.

Miss T. H. E., Amelia Co., Va.: The German's Daughter. So. Lit. Mess., Nov.

Kennedy, J. P.: Suspension of Specie Payments. See Burton's Cyclopedia of Wit and Humor.

*Milward, Mrs. M. G.: Mrs. Shorter's Party. So. Lit. Mess., Jan.

*Milward, Mrs. M. G.: The Yellow Blossom of Glynn. So. Lit. Mess., July.

Poe, E. A.: Mystification (Von Jung).

Poe, E. A.: Why the Little Frenchman Wears His Hand in a Sling.

Poe, E. A.: The Business Man. Burton's Mag., Feb.

Poe, E. A.: The Man of the Crowd, Burton's Mag., Dec.

Preston (?), W. C. :2 Abbot; or The Hermit of the Falls. So. Lit. Mess., Sept.

Simms, W. G.: The Lazy Crow. See Burton's Cyclopœdia of $W$ it and Humor.

*Thompson, W. T.: Major Jones's Courtship; detailed with Other Scenes, Incidents and Adventures in a series of Letters by Himself.

2. On identity of author, see Minor: Southern Literary Messenger, p. 76. 
Poe, E. A.: The Murders of the Rue Morgue. Grahan's Mag., Apr.

Poe, E. A.: A Descent into the Maelstrom. Grahan's Mag., May.

Poe, E. A.: The Island of the Fay. Graham's Mag., June.

Poe, E. A.: The Collority of Monos and Una. Graham's Mag., Aug.

Poe, E. A.: Never Bet the Devil Your Head. Graham's Mag., Sept.

Poe, E. A.: Three Sundays in the Week. Phil. Sat. Ev. Post, Nov. 27.

T. H. E., Amelia Co., Va.: The Autobiography of a Monomaniac. So. Lit. Mess., Oct.

Milward, Mrs. M. G.: Country Annals. So. Lit. Mess., Jan. and Feb.

McCabe, J. P.: Henry Norman and Mary Neville. So. Lit. Mess., July.

1842

Anonymous: Florence Courtland. By a Lady of Va. So. Lit. Mess., Jully.

T. H. E., Amelia Co., Va.: Mrs. Latour. So. Lit. Mess., Aug.

Cliarlton, R. M.: A Court Scene in Georgia. N. Y. Sp. of the Times, Oct.

Longstreet, A. B.: A Night on the Cars. N. Y. Sp. of the Times, Oct.

Poe, E. A.: Eleonora. The Gift.

Poe, E. A.: The Oval Portrait. Graham's Mag., Oct.

Poe, E. A.: The Masque of the Red Death. Graham's Mag., May.

Poe, E. A.: The Landscape Garden. Snowdon's Lady's Comp., Oct.

Poe, E. A.: The Mystery of Marie Roget. Snowdon's Lady's Comp., Nov. and Dec.

1843

Anonymous: The Clairwoods. So. Lit. Mess., July. Signed Charlottesville, Va. 
Anonymous: The Hermit. So. Lit. Mess. Signed Norfolk, Va.

Anonymotis: Rudolph and Alice. Translated from the German by a Lady of Va. So. Lit. Mess., May.

E. M. D. C.: Occoquan, Va.: Female Revenge. So. Lit. Mess., Mar.

Jones, H. C.: A Quarter Race in Kentucky. N. Y. Sp. of the Times, Attg. 5.

*Harris, G. W.: Humorous Stories Contributed to the New York Spirit of the Times.

Longstreet, A. B.: The Old Soldiers. Georgia Scenes-New Series. The Magnolia or So. Appalachian, Mar.

Longstreet, A. B.: The Gnatville Gem. Georgia ScenesNew Series. The Magno, or So. App., June.

Milward, Mrs. M. G.: The Winter Nights Club. So. Lit. Mess., Jan.

Minor, Mrs. B. B.: The Fatal Effects of Insincerity. So. Lit. Mess., Oct.

Poe, E. A.: The Pit and the Pendulum. The Gift.

Poe, E. A.: The Telltale Heart. The Pioneer, Jan.

Poe, E. A.: The Gold Bug. Phil. Dollar Newspaper, June 21, 28.

Poe, E. A.: The Black Cat. Phila. U. S. Post, Aug. 19.

Walker, Miss S.: The Vow. So. Lit. Mess., Apr.

Walker, Miss S.: Lona D'Alvarez: A Tale of the South. So. Lit. Mess., Sept.

\section{4}

Anonymous: De Mortier; a Tale of the French Revolution. Signed Richmond, Va. So. Lit. Mess., Jan.

Anonymous: May Day; a Tale Founded on Fact. Signed Winter Brook, Tenn. So. Lit. Mess., Sept.

*Ingraham, J. H.: Arnold, or the British Spy; a Tale of Treason and Treachery. Ptiblished at the "Yankee Office," Boston.

*Ingraham, J. H.: The Bold Insurgent; a Tale of the Year 1768. In same volume as above.

Longstreet, A. B.: Darby Anvil. So. Lit. Mess. Reprinted from a Georgia paper. 
Minor, Mrs. B. B.: Stephano Colonno. (Prize Story.) So. Lit. Mess., June and July. Signed L. V.?

Poe, E. A.: The Elk (Morning on the Wissahiccon). The Opal, 1844.

Poe, E. A.: A Tale of the Ragged Mountains. Godey's Lady's Book, Apr.

Poe, E. A.: The Spectacles.

Poe, E. A.: Diddling Consiclered as One of the Exact Sciences.

Poe, E. A.: The Balloon Hoax. N. Y. Sun, Apr. 13.

Poe, E. A.: Mesmeric Revelation. Colum. Mag.. Aug.

Poe, E. A.: The Premature Burial. Unknown Phil. journal, Aug.

Poe, E. A.: The Oblong Box. Godey's, Sept.

Poe, E. A.: Thon Art the Man. Godey's, Nov.

Poe, E. A.: The Literary Life of Thingum Bob, Esq., Late Editor of the Goosetherumfoodle. By Himself. So. Lit. Mess., Dec.

Poe, E. A.: The Angel of the Orld. Colum. Mag., Oct.

*Simms, W. G.: The Prima Donna. Godey's Library of Elegant Literature, pp. 110 and 125.

*Thompson, W. T. Second Edition of Major Jones's Courtship.

*Thompson, W. T.: Chronicles of Pineville; embracing Sketches of Georgia Scenes, Incidents and Characters.

\section{5}

Author Unknown: My First Frolic in College. So. Jit. Mess. Signed Joe of Miss.

Author Unknown: Canvassing. So. Lit. Mess., Sept. Signed "T," Gloucester Co., Va.

Harris, G. W.: The Knob Dance; a Tennessee Frolic. N. Y. Sp. of the Times, Aug. 2.

Hentz, Mrs. C.: A Legend of the Silver Wave. So. and West. Mo. Mag. and Rev., Oct.

*Ladd, Mrs. C. S.: Emma Clifford; or The Temptation and the Tritimph. So. Lit. Mess., Nov.

3. On iclentity of author, soe Minor: The Southern Literary Messenger, pp. 110 and 125 . 
Lee, M. E.: Walpurgis Night; or The First Night of May. From the German of Zschopke. So. Lit. Mess., May.

Lee, M. E.: Marie D'Enambuc. A Tale of the Antilles (Altered from the French). So. Lit. Mess., Sept.

Lee, M. E.: Five Eras in the Life of a Woman (From the German of Zschopke). So. Lit. Mess., Oct.

Lee, M. E.: The Prediction (from the French). S. Lit. Mess., Dec.

Poe, E. A.: The Purloined Letter. The Gift, 1845.

Poe, E. A.: The Systcm of Dr. Tar and Prof. Fether. Graham's Mag., Nov.

Poe, E. A.: The Thousand and Second Tale of Scheherazade. Godey's, Feb.

Poe, E. A.: Some Words with a Mummy. Amer. Whig Rev., Apr.

Poe, E. A.: The Power of Worls. Dem. Rev., June.

Poe, E. A.: The Imp of the Perverse. Graham's July.

Poe, E. A.: The Facts in the Case of N. Valdemar. Amer. Whig Rev., Dec.

Simms, W. G.: The Wigwam and the Cabin. (Collection of short tales.) New York.

*Thorpe, I'. B.: The Lig Bear of Arkansas, ancl Other Skctches illustrative of Character and Inciclents in the South ancl Southwest; edlited by Wm. Porter. Phil., Carey \& Hart. 1846

Anonymous: The Rock of Hans Hcilung (from the German of Kœner). So. Lit. Mess., Mar. Signed "Georgia."

Anonymous: Murillo's Pictures. So. Lit. Mess., Mar. Signed "South Carolina."

*Elliott, W.: Carolina Sports by Land and Water: Incluting Incidents of Devil Fishing, Wild Cat, Deer and Bear Hunting. Burges and James, Charleston, S. C.

Harris, C. W.: A Snake Bit Irishman. N. Y. Sp. of the Times, Jan. 17. Signed "Sugartail," Harris's pseudonym."

Harris, G. W.: A Sleepwalking Inciclent. N. Y. Sp. of the Times, Sept. 12.

4. Sec Appl. III, p. 91. 
*Hooper, J. J.: Some Adventures of Capt. Simon Suggs, Late of the Tallapoosa Volunteers; together with Taking the Census and other Alabama Sketches, by a Country Editor. Phil., Carey \& Fart.

*Ingraham, J. H.: The Spectre Steamer and Other Tales. U. S. Putb. Co., Boston.

Jones, H. C.: The Sandy Creek Literary Society. N. Y. Sp. of the Times, Aug. 15.

Lee, M. E.: The Death Knell (from the German of Tromlitz) So. Lit. Mess.. Jan.

Lee, M. E.: The Indian Revenge. A Legend of Toccoa. So. Lit. Mess., Jan.

Lee, M. E.: The Hyacinth (from the German of Flanke), So. Lit. Mess., May.

Milward, Mrs. M. G.: Mrs. Sad's Private Boarding Hotse. So. Lit. Mess., Nov.

Poe, E. A.: The Cask of Amontillado. Godey's, Nov.

Stuart, J. A.: A Fish Story. N. Y. Sp. of the Times, Sept. 12.

\section{7}

Cabell, J. M.: Weal and Woe. So. Lit. Ness., Jan.

*Field, J. M.: The Drama in Pokerville; The Bench and Bar of Jurytown and Otlier Stories. Carey \& Hart, Phila. Also bound in volume with Chronicles of Pineville. (Carey \& Hart, 1850.)

Lee, M. E.: Julia Conzaga. A Tale of Italy. (From the German of Tromlitz). So. Lit. Mess., Mazy.

Poe, E. A.: The Domain of Arnheim. Colum. Mag., Mar.

*Robb, J. S.: Streaks of Squatter Life and Far West Scenes.

R. W. W., Virginia: Ashton Peyton, So. Lit. Mess., Apr.

1848

*Dorr, J. C. R.; Isabel Leslic. $(\$ 100.00$ prize in Sartain's Mag.)

Lee, M. E.: The Statute of Santa Maria. Translatel from Pièrre Chevalier. So. Lit. Mess., Jan.

Lee, M. E.: A Tale of Heligoland (from the German of Wachsman). So. Lit. Mess., May.

Lee, M. E.: The Gray Lady. From the German. So. Lit. Mess., July. 
*Simms, W. G.: Life in America; or the Wigwam and the Cabin. Geo. Clark \& Son, Aberdeen and W. Britain, London. Contents same as first volume with "Mr. Green" and "How Would You Like It" added.

Thompson, W. T.: The Runaway Match. N. Y. Sp. of the Times, Mar. 25.

Walker, S.: The Noted Firm. A Tale. So. Lit. Mess.

\section{9}

*Miles, Geo. H.: Loretta, or The Choice. (Won $\$ 50.00$ prize.) The Catholic Mirror.

Poe, E. A.: Metonta Fanta. Godey's, Feb.

Poe, E. A.: Hop Frog. The Flag of Our Union.

*Thomas, F. W.: Sketches of Character anil Other Tales Founded on Fact. Published at the office of the "Chronicle of Western Literature and Art," Louisville, $\mathrm{Ky}$.

*Wiley, C. H.: The Haunted Chamber; or How They Chose a May Queen in the School of Parson Cole. Sartain's Un. Mag., Jan.

*Wiley, C. H.: The Poor Student's Dream; or The Golden Rule. Same Mag., Jan.

1850

Hooper, J. J.: A Ride with Old Kit Huncker. N. Y. Sp. of the Times, Mar. 16.

Legaré, J. M.: Story of the Haha. So. Lit. Mess., July.

*Windle, Mrs. M. J.: Legends of the Waldenses and Other Tales. Phil.

1851

Anonymous: Winilerhaus: A Tale of Riclmond Thirty Years Ago. Signed "M" Va. So. Lit. Mess., Sept.

Anonymous: Colonel Trediver, the Regulator. Debow's Rev., Jan. Signed "Ibridex," Miss.

Burke, T. A.: Doing a Sheriff. Burton's Cyclopœdia of Wit and Humor.

*Cobb, J. B.: Mississippi Scenes; or, Sketches of Southern and Western Life and Adventure, Humorous, Satirical and De-

5. See Alibone III, 2790. Also Hart's "Female Prose Writers of America," p. 463. 
scriptive, including the "Legend of the Black Creek." Also Includes "The Innkeeper's Wife: a Story of the Revolution." Pub. by A. Hart, Phil. ${ }^{\text {B }}$

*Cooke, P. St. G.: Scenes beyond the Western Border. So. Lit. Mess., 1851, '52, '53.

*Hooper, J. J.: Widow Rugby's Husband and Other Tales of Alabama. A. Hart, Phil.

Hooper, J. J.: Captain M'Spadden; or, the Irish Gentleman in "Purshute of a Schule." Burton's Cyclopœdia of Wit and Humor.

*Hulse, G. A.: Sunbeams and Shadows and Buds and Blossoms. (Short stories.)

Lamar, J. B.: Polly Peablossom's Wedling and Other Tales. First story by Lamar. For other authors, see page 44 .

1852

*Baldwin, J. G.: Sketches of the Flush Times of Alabama and Mississippi. So. Lit. Mess. 1852 and 1853. D. Appleton \& Co., N. Y., 1853.

Bradley, T. B.: My Cousin Paul Coutrine. So. West. Mo., June.

Cooke, J. E.: Peony; a Tale for the Times. So. Lit. Mess., Jan. Signed "Pen Inlington" (pseudonym).

St. Clair, E.: Frances Harcourt; or, The Ill-Timed Jest. So. West. Mo., Aug.

*Thompson, W. T.: Second edition of Chronicles of Pineville. Gretz \& Buck, Phila.

*Webber, Chas. W.: Tales of the Southern Border, Part. I. Lipp. Grambo \& Co., Phila.

\section{3}

*Hentz, Mrs. C. L. W.: Wild Jack; or, The Stolen Child and Other Stories. Phil., A. Hart.

*Hentz, Mrs. C. L. W.: The Victim of Excitement and Other Stories. A. Hart, Phil.

*Southworth, E. D. E. N.: Old Neighborhoods and New Settlements; or, Christmas Evening Legends. A. Hart, Phil.

6. Noticed in So. Lit. Mess., Sept. 1851, p. 584. 
Terhune, Mrs. M. V. (then Hawes) "Marion Harland:" Marrying through Prudential Motives. Godey's, Mar.

*Webber, C. W.: Tales of the Southern Border, Part II. Lipp., Grambo \& Co., Phil.

1854

Anonymotis: The Only Son. By a Virginian. So. Lit. Mess., Fel?.

Baldwin, J. G.: Old Uncle Joln Rosser and the Billy Goat. So. Lit. Mess., Feb.

Baldwin, J. G.: General Gym and Col. Burrows. So. Lit. Mess., April.

*Bowen, Mrs. S. P. K.: Busy Moments of an Iille Woman. D. Appleton \& Co.

Simms, W. G.: The Legend of the Happy Valley and the Beautiful Fawn. So. Lit. Mess.

Terhune, Mrs. M. V. (Hawes) "Marion Harland": The Thrice Wedded. Godley's, July and Aug.

1855

*Holmes, M. J.: The Homestead on the Hill and Other Tales. Orton \& Mulligan, New York.

Terhune, Mrs. M. V. (Marion Harland): The Sympathy Meeting. Godley's Feb.

1856

Author Unknown: The Literary Wife: Signed F. G. R. D., Charlottesville, Va. So. Lit. Mess., Dec.

*Cooke, P. St. G.: Scenes and Adventures in the Army; or Romance of Military Life. Lindsay \& Blackston, Phil.

*Hentz, Mrs. C. L. W.: The Lost Daughter and Other Stories of the Heart.

*Hentz, Mrs. C. L. W.: Courtship and Marriage (short stories). T. B. Peterson, Pliil.

*Hentz, Mrs. C. L. W.: The Banished and Other Stories of the Heart. T. B. Petersor, Phil.

*Simms, W. G.: New Edition "The Wigwam and the Cabin." Redfield, New York.

Terhune, Mrs. M. V.: Helen Benet. Godey's, Jan. and Feb.

*Webber, C. W.: Second Edition of "Tales of the Southern Border." J. B. Lippincott \& Co. 
Bowen, Mrs. S. P. K.: Crimes Which the Law Does Not Reach.

No. I, Gossip. Russell's Mag., Oct.

No. II, The Marriage of Persuasion. Russell's, Nov.

No. III, The Nale Flirt. Russell's, Dec.

*Campana, G. S.: Mora, or The Mysterious Child. So. Lit. Mess., Oct.

Johnston, R. M.: The Goose Pond School; Some Georgia paper.

Bowen, Mrs. S. P. K.: The Best of Friends. (No. IV, Crimes Which the Law Does not Reach.) Russell's, Jan.

Harris, Geo. W.: Sut Lovingood Papers. In Nashville Papers $1858-18610^{\top}$

*Bennett, Mrs. M. H. B.: Leisure Moments (A collection of short tales, essays, and sketches). E. D. Long \& Co., N. Y.

Blount, A. R.: The Sisters. Won $\$ 100.00$ medal. Newbern (N. C.) Gazette.?

* Bowen, Mrs. S. P. K.: Crimes Which the Law Does Not Reach. D'erby \& Jackson, N. Y.

*Ellinjay, Louise: Rising Young Men and Other Tales.

*Skitt (pseud.) : Fisher's River (N. C.) Scenes and Characters. (Sketches.) Harper Bros., N. Y.10

*Thorpe, T. B.: Major Thorpe's Scenes in Arkansas, containing the whole of the Quarter Race in Kentucky, Bob Herring, the Arkansas Bee Hunter, etc., etc. By J. M. Field of the St. Louis Reveille. T. B. Peterson \& Bro., Pliil.

1860

Anonymous: The Old African and His Prayer. DeBow's Review, May.

7. Appl. III, p. 91.

8. Tardy: South. Wri., p. 806.

9. Tardy: South. Wri., p. 432. Also Tardy Li. Fe. Wri., p. 183.

10. See So. Lit. Mess. Jan., 1860, p. 78. Also Atlan. Mo., Jan., 1860, p. 127. 
Anonymous: Southern Sketches. Pub. by J. W. Randolph, Richmond, Va.

Author unknown: Duck Town, by "Skitt" who has been "thar." Signed "Skitt." So. Lit. Mes. Nov.

Author unknown: Unloved. Signed Mabel, Newtonia, Miss. So. Lit. Mess. Feb.

Anderson, R. H.: Bricks, So. Lit. Mess., Dec.

*Bradley, Mrs. M. E. N.: Arthur and Old Stories. Prof. Epis S. S. Union and Church Book Co.

Bryan, M. E.: Twilight at the West Window. So. F. \& F. June 9.

Cooke, J. E.: Phœbe's Wedding Night. So, Lit. Mess. Feb. Taken from So. F. \& F.

*Cowden, Mrs. V. G.: Ellen; or "The Fantastic's Daughter." So. Lit. Mess. Dec.

Emerald, E.: The Black Mask: So. F. \& F., Sept. 1.

*Taylor, Geo. B.: Claiborne (known as the "Oakland Stories").

Towle, Mrs. M. L. W.: The Little Samaritan. So. F. \& F., Oct. 12.

*Whittlesay, S. J. C.: The Stranger's Stratagem, or Double Deceit and Other Stories, M. W. Dodd, N. Y.

\section{1}

Anonymous: Nat Turner's Insurrection. A Story of Cross Keys, Southampton Co., Va. Atlan. Aug.

Anonymous: Afraid: A Story of Alabama. So. Lit. Mess. Apr.

Klutz (psend.): The Old Iron Key. So. Lit. Mess. Mar.

Skitt (pseud.): Parson Squint. By "Skitt" who Has Seen Him. So. Lit. Mess. Jan.

Terhune, Mrs. M. V.: The Black Sheep. Godey's Jan. and Feb.

Thompson, J. M.: The Pool in the Pit. So. F. \& F., May 4. 1862.

Anonymous: John Lamar (War Story). Atlan. Apr.

Anonymous: Gabriel's Defeat. Atlan. Sept. By Author of Nat. Turner's Insurrection. ${ }^{11}$

11. See above, 1861. 
Anderson: Boarding an Engineer. So. Lit. Mess., Mar.

Bagby, G. W.: My Vile Beard. So. Lit. Mess. Sept. and Oct.

Ireton, F. G.: Mura. So. Lit. Mess., Jan.

Ireton, F. G.: Judith. So. Lit. Mess. May.

Rogers, L. B.: The Hasty Marriage. So. Lit. Mess. Apr.

Thompson, J. M.: The Mystery of the Yellow Gables. So. F. \& F. Sept. 20.

1863

Bagby, G. W.: A Horrible Scrape. So. Lit. Mess. Mar.

Bagby, G. W.: My Uncle Flatback's Plantation (sketch). So. Lit. Mess., Oct.

Conway, M. D.: Golden Wedding, Atlan. Apr.

Skitt (pseud.): Jolinson Snow at a "Hottle." So. Lit. Mess., Feb.

Terhune, Mrs. M. V.: Leah Moore's Trial, Godey's Oct. and Nov.

1864

Bell, L.: A Nice Young Man. So. F. \& F. Oct. 15.

Dargan, C. V.: Still Faithful. So. F. \& F. Dec. 17.

DeForrest, V.: How Effie Hamilton Spent Christmas. So. F. \& F., Jan. 23.

Hancock, Mrs. S. J.: Ella Morton. So. F. \& F. Dec.

Johnston, R. M.: Georgia Sketches by an Old Man. Augusta, $\mathrm{Ga}$.

Jones, S., Jr.: The Fortune in the Teacup. So. F. \& F. Feb. 20.

Peck, W. H. The Renegade's Mother. So. F. \& F. Feb. 6. 1865

Terhune, Mrs. M. V.: A Hasty Speech and What Came of It. Godey's Jan. and Feb.

\section{6}

Anonymotis: A Sad Story. The Land We Love, Sept.

Palmer, J. W.: Aunt Judy (A sketch). Atlan. July.

Anonymous: Elsie Beausoleil. The Land We Love., Apr.

Anderton, E.: The Will. So. Home Jour. Dec. 28.

Blanchard, A. D.: An Aid's Story. So. Home Jour., Dec. 28. 
Schele de Vere, M.: The Little Fairy. So. Home Jour. Dec. 7. Schele de Vere, M.: Running the Blockade. So. Home Jour., Dec. 21.

Harris, G. W.: Sut Lovingood's Yarns. Dick \& Fitzgerald, New York.

Hungerford, J.: A Nameless Wonder. So. Home Jour., Dec. 21.

St. John, J. B.: Melrose; or, The Sybil's Warning. So. Home Journal, Nov. 30.

T'erhune, Mrs. M. V.: Entirely at Home. Godey's, Jan, and Feb.

1868

Anonymous: Model Housekeeping: Nelly Random's Dinner Party. The Land We Love, May.

Anonymous: In an Old Drawer. The Land We Love, Dec. Cobb, W. J.: The Old Bachelor. So. Home Jour., Feb. 29. Cooke, P. M.: The Mystic Tie. So. Home Jour., Jan. 4.

Cooke, P. M.: A Strange Man in the House. So. Home Jour., Feb. 15.

Cooke, P. M.: The Headless Horse. So. Home Jour., Jan. 25. Fielding, Fannie: Ashes of Rose. So. Home Jour., Janr. 4. Fielding, Fannie: The Haunted Ship. So. Home Jour., Apr. 4.

Fielding, Fannie: Col. Walchester's Story. So. Home Jour., Apr. 11.

Gray, Edwin: Tom Landon's Scar. So. Home Jour., Feb. 15. Gray, Edwin: A Leap in the Dark. So. Home Jour., July, 11. Hawkins, M. E.: Number Five. So. Home Jour., June 6.

Hungerford, J.: The Golden Fire. So. Home Jour., Feb. 1. Hunter, Mrs. B. K.: A Heart Relation. So. Home Jour., Mar. 28.

Kennedy, M. P.: Glenburne's Housekeeper. So. Home Jour., June 13.

Nelson, W.: Tom Leslithiel's Fix. So. Home Jour., June 20. Roberts, A.: The Diamond Bracelet. So. Home Jour., Oct. 10. Stelle, J. P.: The Haunted Pear Tree. So. Home Jour., Jan. 18.

Stewart, M.: Murder Most Foul. So. Home Jour., Jan. 11. 
Stewart, M.: My Fellow Lodgers. So. Home Jour., Jeb 22. Thompson, M.: A Road Side Story. So. Home Jour., Jan. 11. Way, W. S.: To Be Shot at Sunset. So. Fome Jour., May 30.

1869

Anonymous: Rose Cottage. Signed M. J. H. The Land We Love.

Cooke, J. E.: The Bold Dragoon. So. Home Jour., Jan. 2. Terhune, Mrs. M. V.: Huldah. Godey's Jan.

Terhune, Mrs. M. V.: Almond Blossoms. Godey's, Ju1.

Roberts, A.: Was It a Mistake. So. Home Jour., Jul. 31.

Weiss, Mrs. S. A.: A Dream or Not a Dream? The Land We Love.

\section{0}

Johnston, R. M.: The Goose Pond School. The New Eclec. Nov. and Dec.

Johnston, R. M.: Juclge Mike's Court. New Ecles., Jan. and Feb.

Johnston, R. M.: How Mr. Bill Williams Took the Responsibility. New Eclec., Mar.

Johnston, R. M.: The Pursuit of Mr. Adiel Stack. New Eclec. Apr. and May.

Johnston, R. M.: The Early Majority of Mr. Thos. Watts. New Eclec., June.

Johnston, R. M.: The Organ Grinder. New Eclec. Jul.

Johnston, R. M.: Mr. Williamson Slippey and His Salt. New Eclec., Oct.

Terhune, Mrs. M. V.: Rich or Poor. Godey's Jan.

Terhune, Mrs. M. V.: Taking Him at His Word. Godey's Oct.

\section{1}

Anonymous: A Texan Experience. Signed E. G. L. So Mag., Mar.

Deas, A. S.: The Old Bachelor's Married Life. So. Mag, Mar.

Deas, A. S.: A visit to Fred. So. Mag., Sept.

Dorr, J. C.: My Husband's First Love. Scrib., Jul.

Terhune, Mrs. M. V.: One Old Maid. Godey's, Jan. 
Terhune, Mrs. M. V.: The Heart of John Stewart. Godey's Jul.

Hutson, W.: Strawsberry Vale. So. Mag., May.

Johnston, R. M.: Dukesborough Tales. Baltimore.

Longstreet, A. B.: A Family Picture, So. Mag. Feb.

Spencer, E.: Hunting a Dragon. So. Mag. Aug.

Turner, C. F.: An Adventure in North Carolina. So. Mag., Sept.

1872

Deas, A. S.: The Ghost at Mansfield. So. Mag., Nov. Terhune, Mrs. M. V.: Abigail's Waiting. Godey's, Feb. Manners, R.: Christmas Moonlight Masking. So. Mag., Feb. Spencer, E.: Mother Beeblossom's Shop. So. Mag., Mar. Spencer E.: A Slight Tcothache. So. Mag. Jutl.

Spencer, E.: Mehitabel's Nose. So. Mag., Nov.

\section{3}

Cable, G. W.: "Sieur George. Scrib., March.

Deas, F. M. P.: Our Governess. So. Mag., June.

Marsdale, C.: Cousin Jack. So. Mag., Dec.

Moore, Mrs. M. V.: Betsy's trip to Town. Some Talladega paper.

Spencer, E.: A Ghost Who Made Himself Useful. Scrib. M., Mar.

Tierman, Mrs. M. S.: A Lotus of the Nile. Lipp., Sept.

1874

Cable, G. W.: Belles Demoisellses Plantation. Scrib. M., Apr.

Cable, G. W.: 'Tite Poulette. Scrib. M., Oct.

Cooke, J. E.: Pretty Mrs. Gaston and Other stories.

Cooke, J. E.: A House in the Blue Ridge. So. Mag., June.

Deas, A. S.: The Village Genius. So. Mag., May.

Stabler, J. L. "Witched." So. Mag. Dec.

Terhune, Mrs. M. V.: The Brown Opal. Godey's, Feb.

1875

Cable, G. W.: Jean-ah Poquelin. Scrib. M. May.

Cable, G. W.: Madame Délicieuse. Scrib. M., Aug. 
Stabler, J. L.: A Perfect Treasure. So. Mag. June.

Tiernan, Mrs. F. F.: The Story of a Conspiracy. Lipp., Oct. 1876

Cable, G. W.: Café des Exiles. Scrib. M., Mar.

Harrison, Mrs. W. B.: A Little Centennial Lady. Scrib. M., July.

1877

Burnett, F. H.: Lodusky. Scrib. M. Sept.

Burnett, F. H.: Seth. Lipp., Mar.

Burnett, F. H.: Esmeralda. Scrib. M., May.

Burnett, F. H.: Le Monsieur de la Petite Dame. Scrib. M., June.

Burnett, F. H.: Sweethearts. Scrib. M.. Aug.

Cooke, J. E.: A Craniologist. Harper, Jan.

Cooke, J. E.: Old Wiley: Harper, Apr.

Mosby, E. F.: The Clristmas Inn and Other Stories.

1878

Barry, A.: A Terrible Revenge. So. Atlan., Nov.

Bonner, K. S.: C. G., Or Lily's Earrings. Lipp., Sept.

Bonner, K. S.: Aunt Mely's Cabin. Lipp., Feb.

Cooke, J. E.: Owlet. Harper, Jul.

Duval, A.: The Old Story. So. Atlan. Dec.

Elam, W. C.: The Mountain Horror. So. Atlan. Apr.

Harrison, Mrs. W. B.: Golden Rod.

Jones, E. R.: Monsieur Fanfaron. So. Atlan. May.

Murfree, M. N.: The Dancing Party at Harrison's Cove. Atlan., May.

Murfree, M. N.: The Star in the Valley. Atlan., Nov.

1879

Bonner, K. S.: The Revolution in the Life of Mr. Ballingall. Harper, Oct.

Cable, G. W.: Old Creole Days.

Cooke, J. E.: Moonshiners. Harper, Feb.

Gordon, A. C.: How African William Stopped Off. So. Atlan., Mar. 
Johnston, R. M.: Mr. Neclus Peller's Conditions. Scrib. M., June.

Stuart, G.: The Evil Eyc. So. Atlan. Feb.

1880

Bonner, K. S.: Hieronymous Pop and the Baby. Harper, June.

Bonner, K. S.: A Volcanic Interlurle. Lipp., Apr.

Cooke, J. E.: A Boating Adventure. Harper, Aug.

Harris, J. C.: Uncle Renus, His Songs and Sayings. Appleton \& Co., New York

Murfree, M. N.: Taking the Blue Ribbon at the Fair. App. Sum. Bk.

Murfree, M. N.: Electionerin' on Big Injun Mounting. Atlan. Jan.

Murfrce, M. N.: The Rcmance of Sùnrise Rock. Atlan. Dec. Peters, Mrs. M. S.: Cupido. Godey's, Aug.

Torrence, M.: A Modern Lamia. So. Atlan. Dec.

\section{1}

Bonner, K. S.: Two Storms. Harper, Apr.

Bonner, K. S.: Sister Weeden's Prayer. Lipp., Apr.

Cooke, J. E.: The Sumac Gatherers. Harper, Nov.

Dimitry, C.: The Portrait. So. Atlan. Oct.

Early, M. C.: Sambo's Banishment. So. Atlan. Sept.

Johnston, R. M.: The Various Languages of Billy Moon. I-Tarp., Aug.

Johnston, R. M.: Puss Tanner's Defense. Harper, Feb.

Jolnnston, R. M.: The Unexpected Parting of the Beazley

Twins, Hatp., May.

Harris, J. C.: A Rainy Day with Uncle Remus. Cent., June, Jul., and Aug.

Magruder, J.: Young America in England. Lipp., Oct.

Murfree, M. N.: Over on the Tother Mounting. Atlan., June.

Peters, Mrs. M. S.: Titian's Daughter. Godey's, Feb.

Torrence, M.: Auld Robin Gray. So. Atlan., Sept.

Torrence, M.: Enceladis. So. Atlan., Oct. 
Bonner, K. S.: On the Nine Mile. Harp., May.:

Johnston, R. M.: The Jonce Tramwell Compromise. Harp., Jan.

\section{3}

Bonner, K. S.: Dialect Tales. Harper Bros., New York.

Harris, J. C.: At Teague Poteat's. Cent., May.

Harris, J. C.: Nights with Uncle Remus. Cent., Jul., Aug., Sept.

Harris, J. C.: Nights with Uncle Remus. Houghton, Miffin \& Co., Boston.

Murfree, M. N.: The Harnt that Walks Chilhowee. Atlan., May.

Murfree, M. N.: A-Playing of Old Sledge at the Settlement. Atlan., Oct.

Thompson, W. T.: John's Alive; or, the Bridge of a Ghost and Other Sketches. (Posthumous.)

1884

Bonner, K. S.: Suwanee River Tales. Roberts Bros., Boston.

Cooke, J. E.: Toinette. Harp., Dec.

Harris, J. C.: Free Joe and the Rest of the World. Cent., Nov.

Harris, J. C.: Mingo and Other Sketches in Black and White. Houghton, Miffin \& Co., Boston.

Johnston, R. M.: The Brief Embarrassment of Mr. Iverson Blount. Cent., Sept.

Murfree, M. N.: Drifting Down Lost Creek. Atlan., Mar. and Apr.

Murfree, M. N.: In the Tennessee Mountains. Houghton, Miffin \& Co.. Boston.

Page, T. N.: Marse Chan. Cent., Apr.

Allen, J. L.: Too Much Momentum. Harp., Apr. Edwards, H. S.: Elder Brown's Backslide. Harp. F-Tarrison, Mrs. W. B.: Crow's Nest. Cent., Sept. Jolnston, R. MI: The Meditations of Mr. Archie Kittrell. Cent., Apr. 
McGill, M. T.: A Georgian at the Opera. Harp., June. Murfree, M. N.: Way Down in Lonesome Cove. Harp., Dec. Thompson, M.: Hodson's Hicle Out. Cent., Mar.

Thompson, W. T.: A Red Headed Family. South. Biv., June.

1886

Crim, M.: An "Unfortunit Creetur." Cent., Feb.

Cunningham, L. T.: The Price He Paid. South. Biv., Jul. Edwards, H. S.: Two Runaways. Cent., Jul.

Floyd, M. S.: Uncle Adan's Funeral Feast. South. Biv., Mar. Fitz Hugh, M. N.: At Rickettses' Play Party. So. Biv., Dec. Gordon, W. F.: Under Sentence of Death. So. Biv., Mar. Harris, J. C.: Trouble on Lost Mountain. Cent., Jan.

Johnston, R. M.: The Hotel Experience of Mr. Pink Fluker. Cent., June.

King, G. E.: Bonne Maman. Harp., Jul.

McGill, M. T.: "Sis." Harp., Jan.

Page, T. N.: Unc' Edinburg's Drowndin'. Harp., Jan.

Page, T. N.: Ole Stracted. Harp., Oct.

Page, T. N.: Polly. Harp., Dec.

Page, T. N.: Meh Lady. Century, June.

Page, T. N.: A Soldier of the Empire. Cent., Oct.

Pendleton, L.: The Story of Black Dan. So. Biv., Feb.

Shepperd, E.: Mistress Betsey Shepperd. So. Biv., Aug.

Smith, N.: My First Conquest. So. Biv., Oct.

Stullivan, D. E. O.: Among the Hills of Atlanta. So. Biv., May.

Troubetzkoy, A.: A Brother to Dragons. Atlan., Mar.

Wood, H. C.: At the Mountain Still. So. Biv., Sept.

1887

Baylor, F. C.: Timothy Chubb and the Cold Punch. Cos., Dec.

Cable, G. W.: Carancro. Cent., Jan. and Feb.

Cable, G. W.: Grande Pointe. Cent., Mar.

Cleveland, H. W.: Old Scipio. So. Biv., Apr.

Cooke, J. E.: The Lynhaven Cross. Cos., Dec.

Cooke, J. E.: Mr. and Mrs. Inderwick. Cos., Oct.

Crim, M.: S'phiry Ann. Cent., Feb. 
Edwards, H. S.: Sister Todhunter's Heart. Cent., Jul. Gordon, A. C.: Flandroe's Mogul. Scrib., Sept.

Harb, L. C.: Jessamine. So. Biv., Feb.

Harris, J. C.: Aunt Fountain's Prisoner. Scrib., Mar.

Harris, J. C. Free Joe and Other Georgia Sketches. Chas. Scribner's Sons.

Harris, J. C.: Little Compton. Cent., Apr.

King, G. E.: Bayou L'Ombre. Harp., Jul.

Johnston, R. M.: The Wimpy Adoptions. Cent., Jan.

Johnston, R. M.: Martha Reid's Lovers. Harp., Jan.

Johnston, R. M.: The Rivalries of Mr. Toby Gillam. Harp., Mar.

Johnston, R. M.: The Stubblefield Contingents. Harp., Apr. Johnston, R. M.: Moll and Virgil. Harp., Sept.

Murfree, F. D.: The Show that Came to Sequatchee Valley. Cos., Nov.

Murfree, M. N.: His Day in Court. Harp., Dec.

Page, T. N.: No Haid Pawn. Scrib., Apr.

Page, T. N.: In Ole Virginia. Chas. Scribner's Sons.

Peters, Mrs. M. S.: Hi Roack's Lost Shadow. So. Biv., May.

Troubetzkoy, A.: Nurse Crumpet Tells the Story. Harp., Sept.

Troubetzkoy, A.: The Story of Arnon. Harp., Nov.

Troubetzkoy, A.: "Inja." Harp., Dec.

Troubetzkoy, A.: The Farrier Las o' Piping Pebworth. Lipp., Jul.

1888

Allen, J. L.: Two Kentucky Gentlemen of the Old School. Cent., Apr.

Allen, J. L.: The White Cowl. Cent., Sept.

Cable, G. W.: Au Large. Cent., Nov.

Cable, G. W.: Bonaventure. ${ }^{12}$ Chas. Scribner's Sons.

Cable, G. W.: Strange True Stories of Louisiana. Chas. Scribner's Sons.

Edwards, H. S.: De Valley an de Shadder. Cent., Jan.

Edwards, H. S.: An Idyl of Sinkin Mountin. Cent., Oct.

12. For contents of volume, see p. 60 . 
Edwards, H. S.: "Minc-a Plot." Cent., Dec.

Harris, J. S.: Ananias. Harp., Apr.

Johnston, R. M.: The Experiments of Miss Sally Cash. Cent., Aug.

Johnston, R. M.: The Campaigns of Potiphar McCray and Others. Cos., Feb.

Johnston, R. M.: Mr. Absalom Billingslea and Other Georgia Folk. Harper \& Bro., Franklin Square Lib.

Johnes, C. C.: Negro Myths from the Georgia Coast Told in the Vernacular. Houghton, Mifflin \& Co.

King, G. E.: The Christm!as Story of a Little Church. Harp., Dec.

Meriwether, L.: Mountain Life in Tennessee. Cos., Feb. Pendleton, L. B.: Betwitched and Other Stories.

Scott, S. S.: Southern Tales and Sketches.

Stuart, Mrs. R. McE.: Lamentations of Jeremiah Johnson. Harp.

Troubetzkoy, A.: Virginia of Virginia. Harp., Jan.

Troubetzkoy, A.: The Man of the Golden Fillet. Lipp., Feb.

1889

Allen, J. L.: King Solomon of Kentucky. Cent., June.

Cable, G. W.: Salome Muller. Cent., May.

Cable, G. W.: The Flaunted House in Royal Street. Cent., Ang.

Cable, G. W.: Attalie Brouillard. Cent., Sept.

Edwards, H. S.: A Born Inventor. Cent., Apr.

Edwards, H. S.: The Rival Souls. Cent., Mar.

Edwards, H. S.: Tom's Strategy. Cent., May.

FitzHugh, N. M.: T'other Miss Mandy. Harp., June.

Harris, J. C.: The Ot.l Bascom Place., Cent., Aug., Sept., Oct.

Johnston: Ogeechee Cross Firings. Harp.

McClelland, M. G.: Mollie. Harp., Ang.

Preston, M. J.: Aunt Dorothy's Funeral. Harp.

Robertson, H.: How the Derby Was Won. Scrib., Jul.

Rosebro, V.: A Jest of Fate. Cent., Apr.

Smith, F. H.: Captain Joe. Cent., Dec.

Stuart, R. McE.: A Golden Wedding. Harp., Dec. 
Thompson, M.: Ben and Judas. Cent., Oct. Tiernan, M. S.: Two Negatives. Cent., Feb.

1890

Allen, J. L.: Posthumous Fame. Cent., Mar.

Allen, J. L.: Sister Dolorosa. Cent., Dec., Jan. and Feb., 1891.

Boyle, V. F.: How Jerry Brought Malviney. Cent., Oct.

Cable, G. W.: The Clock in the Sky. Harp., Sept.

Crim, M.: Truth and Untruth. Harp., Jul.

Crim, M.: Two Points of View. Harp., June.

Crim, M.: The Crucial Test. Cent., Jan.

Edwards, H. S.: How Sal Came Through. Cent., Feb.

Harris, J. C.: A Conscript's Christmas. Cent., Dec.

Johnston, R. M.: Mr. Gibble Colt's Ducks. Harp., Dec.

Jolnnston, R. N.: The Pursuit of the Martyns. Cos., Nov. and Dec.

Johnston, R. M.: The Self-Protection of Mr. Littlebury Roach. Cent., May.

King, G. E.: Maclrilene. Harp., Nov.

McClelland: The Tragedy of Humpback. Harp., Apr.

Page, T. N. P'laskie's Tunaments. Harp., Dec.

Page, T. N.: George Washington's Last Duel. Cos., Apr.

Rosebro, V.: The Last Marchbanks. Cent., Mar.

Rosebro, V.: Rudolph, Atlan., Mar.

Rosebro, V.: The Reign of Reason. Cent., Jul.

Thompson, M.: A Pair of Old Boys. Cent., Dec.

1891

Allen, J. L. : Flute and Violin and Other Kentucky Tales and Romances. Macmillan.

Baylor, F. C.: A Shield and a Helmet. Lipp., Jul.

Crim, M.: - In Beaver Cove. Cent., May.

Crim, M.: 'Zeki'1. Cent., Sept.

Crim, M.: Was It an Exceptional Case? Cent., Oct.

Harris, J. C.: Balaam and His Master. Cent., Feb.

Harrison, Mrs. C. C.: Penelope's Swains. Cent., Jan.

Johnston, R. M.: Old Gus Lawson. Cent., May.

Johnston, R. M.: A Moccasin among the Hobbys. Lipp., Dec. 
Johnston, R. M.: A Surfrise to Mr. Thompson Byers. Lipp., Jul.

Johnston, R. M.: The Primes and Their Neighbors. D. Appleton \& Co., New York.

King, G. E.: Making Progress. Harp., Feb.

Page, T. N.: Elsket. Scrib., Aug.

Rosebro, V.: The Force of Example. Cent., Jul.

Rosebro, V.: The Clown and the Missionary. Cent., Aug.

Smith, F. H.: An Escapade in Cordova. Cent., Oct.

Smith, F. H.: Espero Gorgoni, Gondolier. Scrib., Dec.

Stuart, Mrs. R. McE.: Christmas Gifts. Lipp., Jan.

Stuart, Mrs. R. McE.: The Widder Johnsing. Harp., Nov.

Thompson, J. M.: A Race Romance, Cent., Apr.

1892

Boyle, V. F.: De Hant er Buzzard's Nest. Cent., Feb.

Bush, S. S.: 'Postle Paul's Reminatin'. Fetter's So. Mag., Oct.

Cabell, F. B.: For Tom and Money. Fetter's So. Mag., Oct. Carlyle, C.: The Priest of the Soul. Fetter's So. Mag., Oct. Carlyle, C.: Mrs. Alwayn's Christmas. Fetter's So. Mag., Dec. Crippin, A.: A Mule with a Mission. Fetter's So. Mag., Sept. Edwards, H. S.: A Battle in Crackerdom. Cent., Jan.

Edwards, H. S.: Captain Jerry. Cent., Jan.

Edwards, H. S.: Charley and the Possum. Cent., May. Uncle Ben and Old Henry. Cent., Feb.

Erwin, W.: The Fiddler of Linnville Cove. Fetter's So. Mag., Sept.

Fox, J., Jr.: A Mountain Europa. Cent., May and June.

Harris, J. C.: A Belle at St. Valerien. Atlan., Mar.

Harris, J. C.: Uncle Remus and His Friends. Houghton, Mifflin \& Co.

Harris, J. C.: On the Plantation, D. Appleton \& Co.

Harrison, Mrs. C. C.: Monsieur Alcibiade. Cent., Feb.

Harrison, Mrs. C. C.: Gay's Romance. Cent., Mar.

Harrison, Mrs. C. C.: When the Century Came In. Scrib., Aug.

Harrison, Mrs. C. C.: A Daughter of the South. Cent. 
Harrison, Mrs. C. C.: Crow's Nest and Bellhaven Tales. Century $\mathrm{Co}$.

Johnston, R. M.: A Bachelor's Counselings. Cent., Sept. Johnston, R. M.: Mr. Billy Downs and His Likes.

Johnston, R. M.: Mr. Fortner's Marital Claims and Other Stories, D. Appleton \& Co.

Johnston, R. M.: New edition of Dukesborough Tales. D. Appleton \& Co.

King, G. E.: A Drama of Three. Cent:, Dec.

McClelland, M. G.: Touch and Go. Lipp., Mar.

Murfree, M. N.: The Casting Vote. Cent., Nov. and Dec.

Page, T. N.: Outplaying "Gabrul." Harp., Apr.

Page, T. N.: Little Mordecai. Harp., May.

Page, T. N.: 'Relius. Harp., Aug.

Page, T. N.: Learning Geography. Harp., Sept.

Page, T. N.: Buck. Harp., Oct.

Page, T. N. The True Story of the Surrender of the Marquis Cornwallis.

Page, T. N.: Elsket and Other Stories. Chas. Scribner's Sons.

Page, T. N.: A Gray Jacket. Cent., May.

Page, T. N.: My Cousin Fanny. (Sketch.) Cent., Dec.

Page, T. N.: Miss Dangerlie's Roses. Scrib., Nov.

Rosebro, V.: The Girl and the Problem. Cent., June.

Rosebro, V.: The Village Alien. Cent., Oct.

Shober, C. E.: Uncle Henry's Prayer. Fetter's So. Mag., Sept.

Shober, C. E.: Old Science's Christmas Dinner. Fetter's So. Mag., Dec.

Smith, F. H.: A Knight of the Legion of Honor. Cent., Dec.

Stuart, Mrs. R. McE.: Jessehiah's Brown's Courtship. Harp., May.

Thompson, J. M.: Rudges and Gum. Cent., Jul.

1893

Benet, S. E.: Dolciner. Fetter's So. Mag., Oct.

Bicknell, F. M.: Ten Thousand Short. Fetter's So. Mag., Sept. 
Cable, G. W.: The Taxidermist. Scrib., May.

. Cleveland, H. W.: Why She Acted Queer. Fetter's So. Mag., Jan.

Crim, M.: The Cross Roads Ghost. Lipp., Sept.

Crippin, A.: At the Golden Dove. Fetter's So. Mag., Aug. Eggleston, G. C.: The Redemptioner. Cent., Aug.

Halleck, R. P.: Her Astral Shape. Fetter's So. Mag., May. Harben, W. N.: Before Two Altars. L. H. J., May and June. Harris, J. C.: The Comedy of War. McClure, June.

Harris, J. C.: The Mystery of the Red Fox. Scrib., Oct.

Harris, J. C.: The Baby's Christmas. Cent., Dec.

Johnston, R. M.: Ishmael. Lipp., Sept.

Johnston, R. M.: Mr. Cummins' Relinquishment. Cent., Nov.

King, G. E.: La Grande Demoiselle. Cent., Jan.

King, G. E.: Mini's Marriage. Cent., Feb.

King, G. E.: The Miracle Chapel. Cent., Feb.

King, G. E.: The Story of a Day. Cent., June.

King, G. E.: Anne Marie and Jeanne Marie. Cent., Jul.

King, G. E.: A Crippled Hope. Cent., Jul.

King, G. E.: One of Us. Cent., Aug.

King, G. E.: The Little Convent Girl. Cent., Aug.

King, G. E.: Grandmother's Grandmother. Cent., Sept.

King, G. E.: The Old Lady's Restoration. Cent., Sept.

King, G. E.: A Delicate Affair. Cent., Oct.

King, G. E.: Pupasse. Cent., Oct.

Lynde, F.: Nan. Fetter's So. Mag., Mar.

Lynde, F.: Bud Hester's Legacy. Fetter's So. Mag., Sept.

Mathis, M. O.: Mars Bogan. Fetter's So. Mag., Mar.

Murfree, M. N.: The Phantoms of the Foot Bridge. Harp., Dec.

Page, R.: The Pass'n's Grip. Lipp., Oct.

Page, T. N.: The Prosecution of Mrs. Dullet. Harp., Jan.

Page, T. N.: The Danger of Being Thorough. Harp., Feb.

Page, T. N.: Billington's Valentine. Harp., Mar.

A Story of Charlie Harris. Harp., Apr.

Page, T. N.: How Jinny Eased Her Mind. Harp., May.

Page, T. N.: He Would Have Gotten a Lawyer. Harp., June.

Page, T. N.: How Andrew Carried the Precinct. Harp., Jul. 
Page, T. N.: Rasmus. Harp., Aug.

Page, T. N.: Her Sympathetic Editor. Harp., Sept.

Page, T. N.: He Knew What Was Due to the Court. Harp., Oct.

Page, T. N.: Her Great Grandmother's Ghost. Harp., Nov.

Page, T. N.: Charliee Whitler's Christmas Party. Harp., Dec.

Page, T. N.: Rachel's Lovers. Harp.. Dec.

Pollard, J. P.: Miss Belle's Lovers. Fetter's So. Mag., Nov.

Read, O.: Josh Tabb, the Poet. Fetter's So. Mag., Aug.

Read, O.: In the Cypress View Neighborhood. Cos., June.

Robertson, H.: The Rich Miss Girard. Scrib., Sept.

Rollston, A. D.: Jed. Fetter's So. Mag., Dec.

Rosebro, V.: A Glimpse of an Artist. Scrib., Apr.

Scott, M. McN.: Affika Town. Fetter's So. Mag., Autg.

Shields, S. J.: The Sheik's Revenge. Fetter's So. Mag,, Aug.

Spottswood, F. D.: The Lost Jonah. Fetter's So. Mag., Jul.

Starnes, H.: Brother Amen's Accident. Fetter's So. Mag., Feb.

Stuart, Mrs. R. McE.: Bucl Zunt's Mail. Harp., Dec.

Stuart, Mrs. R. McE.: A Golden Wedding and Other Tales. Harpar \& Bro.

Tyler, C. W.: The Miracle at Mrs. Smiley's. Fetter's So. Mag., Dec.

Williams, Mrs. M. McC.: A Laggard in Love. Scrib., Nov. 1894

Boyle, V. F.: Old Bia's Vision. Cent., Aug.

Chopin, K. O.: Tante Cat'rinette. Atlan., Sept.

Edwards, H. S.: Isom and the Major.

Harben, W. N.: The Heresy of Abner Calihan. L. H. J., Jul. Harris, J. C.: The Late Mr. Watkins of Georgia. Lipp., Mar. Johnston, R. M.: Mr. Ebenezer's Bull's Investments. Cent., Feb.

Johnston, R. M.: Mr. Pate's Only Infirmity.

Johnston, R. M.: Little Ike Templin and Other Stories. Lothrop Pub. Co., Boston.

King, G. E.: An Aftair of the Heart. Hary., I.: $^{\circ}$ 
King, G. E.: At Chenire Carminade. Harp., May.

King, G. E.: Grandmama. Cent., June.

King, G. E.: An Evening Party. Harp., Jul.

King, G. E.: An Interlude. Harp., Nov.

Mayhew, Mrs. B. F.: In the Piney Woods. Harp., Oct.

Page, T. N.: John's Wedding Suit. Harp., Jan.

Page, T. N.: When the Colonel Was a Duellist. Harp., Feb.

Page, T. N.: The Old Gentleman of the Black Stock. Harp., Oct.

Page, T. N.: How Alick Thompson Played It. Harp., Nov.

Page, T. N.: Rachel's Lovers. Harp., Dec.

Page, T. N.: The Burial of the Guns. Scrib., Apr.

Page, T. N.: Little Darby. Scrib., Sept. and Oct.

Page, T. N.: Pastime Stories. Chas. Scribner's Sons.

Robertson H.: She and Journalism. Scrib., Aug.

Rosebro, V.: Her Mother's Success. Cent., Jul.

Seawell, M. E.: Frenchy, Lipp., Jan.

Seawell, M. E.: Maid Marion and Other Stories. D. Appleton \& Co.

Snith, F. H.: A Gentleman Vagabond. Cent., Sept.

Smith, F. H.: "Tincter" of Iron. Harp., Apr.

Smith, F. H.: Never Had No Sleep. Harp., Oct.

Stuart, Mrs. R. McE.: A Pulpit Orator. Harp., Mar.

Stuart, Mrs. R. McE.: The Second Mrs. Slimm. Harp., May.

Stuart, R. McE.: The Dividing Fence. Harp., Dec.

Stuart, R. McE.: A Christmas Guest. Cent., Dec.

Stuart, R. McE.: Carlotta's Intended anrl Other Stories.

Harper and Bro.

1895

Baylor, F. C.: The Pet Meanness. Lipp., Nov.

Brown, W. W.: Judly and Other Sketches (negro character).

Crin, M.: The Strike at Mobley's. Cent., Jul.

Dawson, Mrs. T. N.: A Tragedy of South Carolina. Cos., Nov,

Edwards, H. S.: The Hard Trigger. Cent., Mar.

Elwards, H. S.: The Gum Swamp Debate. Cent., Sept.

Edwards, H. S.: Where the Clues Met. Lipp., Dec.

Egan, L. H.: A Bundle of Fagots. (Stories.) 
Ewell, A. M.: Come Down. Atlan., Feb.

Harris, J. C.: The Colonel's "Nigger Dog." Scrib., Dec. Harrison, Mrs. C. C.: The Merry Maid of Arcady. Harp., Jan.

Johnston, R. M.: Their Cousin Letty. Cent., Jan.

Johnston, R. M.: Two Shadowy Rivals. Cent., May.

King, G. E.: A Domestic Interior. Harp., Feb.

Smith, F. H.: John Saunders, Laborer. Harp., Jan.

Smith, F. H.: A Waterlogged Town. Harp., Mar.

Smith, F. H.: Five Meals for a Dollar. Harp., Oct.

Smith, F. H.: The Lady of Lucerne. Cent., June.

Smith, F. H.: Jonathan. Cos., May.

Snith, F. H.: A Gentleman Vagabond and Some Others. Houghton, Mifflin \& Co.

Stuart, Mrs. R. McE.: The Middle Hall. Harp., Jan.

Stuart, Mrs. R. McE.: Moriah's Mourning. Harp., Jan.

Stuart, Mrs. R. McE.: The Boy. Cent., Feb.

Thompson, M.: The Balance of Power. Harp., Apr.

Thompson, J. M.: A Friend to the Devil. Lipp., Aug.

Winston, A. S.: A Co-operative Courtship. Scrib., June.

\section{6}

Altsheler, J.: A Spy of France. Cos., Jul.

Barbe, Waitman: In the Virginias. (Short Stories.)

Baylor, F. C.: Belle's Beaux. Cos., Sept.

Cable, G. W.: Gregory's Island. Scrib., Aug.

Edwards, H. S.: Mas. Craffud's Freedom. Cent., May.

Edwards, H. S.: The White Spider. Cent., Nov.

Elliott, S. B.: Miss Maria's Revival. Harp., Aug.

Elliott, S. B.: Faith and Faithfulness. Harp., Oct.

Fox, J., Jr.: Hell for Sartain and Other Stories. Harper \& Bros.

Harben, W. N.: The Whipping of Uncle Henry. Lipp., Dec.

Harris, J. C.: A Baby in the Siege. Scrib., Apr.

Harris, J. C.: The Baby's Fortune. Scrib., Nov.

Harris, J. C.: Daddy Jake, the Runaway. (Volume of stories.) Houghton, Mifflin \& Co.

Harris, J. C.: Balaam and His Master. (Volume of Stories.) Houghton, Mifflin \& Co. 
Johnston, R. M.: Old Lady Lazenberry. Cent., Jul. McGowan, A.: A Hard Answer. Lipp., Sept.

Meekins, L. R.: Abner. Cent., Sept.

Rosebro, V.: The Sayings and Doings of the Todds. Cent. June.

Smitl, F. H.: One of Bob's Tramps. Harp., Aug.

Sprunt, J.: Tales and Traditions of the Lower Cape Fear.

Stuart, Mrs. R. McE.: The Unlived Life of Little Mary Ellen. Harp., Oct.

Stuart, Mrs. R. McE.: A Slender Romance. Cent., Jan.

Stuart, Mrs. R. McE.: Solomon Crow's Christmas Pockets and Other Stories. Harper \& Bro.

Stuart, Mrs. R. McE.: Sonny's Diploma. Cent., Sept.

Stuart, Mrs. R. McE: Sonny's Keepin Company. Cent., Oct.

Thompson, M.: Resaca. Lipp., May:

Thompson, M.: A Jocund Fiend. Cos., Dec.

Williams, Mrs. M. McC.: A Black Settlement. Harp., Oct. Winston, A. S.: Mrs. Thompson's Ten. Cent., Aug.

Winston, A. S.: The Protege. Cent., May.

1897

Baylor, F. C.: Butterfield \& Co., Atlan., Aug. \& Sept.

Baylor, F. C.: The Confessions of a Physician. Cos., May. Baylor, F. C.: Four Sweethearts and a Wife. Cos., Sept. Chopin, K.: Neg Creol. Atlan., Jul.

Elliott, S. B.: Squire Kayley's Conclusions. Scrib., Dec.

Harris, J. C.: A Run of Luck. Scrib., Dec.

Harrison, Mrs. C. C.: Miss Selina's Settlement. Cent., Feb. Johnston, R. M.: Our Witch. Cent., Mar.

Johnston, R. M.: Old Times in Mildle Georgia. Macmillan Co.

Kennedy, S. B.: The Assembly Ball. Harp., Feb.

King, G. E.: A Quarrel with God. Out., Mar. 6.

Moore. J. T.: Songs and Stories from Tennessee.

Murfree, M. N.: The Young Mountaineers. Houghton, Miffin \& Co.

Scott. S. S.: The Mobilians. (Short Stories.)

Seawell, M. E.: The True Story of Commodore Lievre. Scrib., Aug.

Stuart, Mrs. R. McE.: An Optical Dilemma. Harp., Jan. 
Stuart, Mrs. R. McE.: The Various Tempers of Grandmother Grigg. Harp., Sept.

Terhune, Mrs. M. V.: Some Colonial Homesteads and Other Stories.

Thompson, M.: The Defense by Resurrection. Cent., Jul.

Winston, A. S.: The Jilting of Mary Ellen. L. H. J., Aug.

1898

Altsheler, J. P.: After the Battle. Lipp., Mar.

Dunbar, P. L.: The Diliberation of Mr. Dunkin. Cos., Apr. Eggleston, G. C.: Southern Soldier Stories. The Macmillan Co.

Elliott, S. B.: Baldy. Harp., Feb.

Elliott, S. B.: An Incident. Harp., Feb.

Ewell, A. M.: Miss Stacy's Buryin' Money. Cent., Jan.

Hampton, Mrs. K. P.: A Flag of Truce and Other Stories.

Harben, W. N.: Jim Trundle's Crisis. Lipp., Mar.

Harben, W. N.: The Tender Link. L. H. J.. Sept.

Johnston, R. M.: A Challenge. Cent., Apr.

King, G. E.: Destiny. Harp., Mar.

McGowan. A.: The Ark in the Wilderness. Lipp., Apr.

Meguire, A. S.: With Music and White Light. Harp., June.

Robertson, H.: Drummed Out. Scrib., Oct.

Smith, F. H.: A Kentucky Cinderella. L. H. J., Dec.

Stuart, Mrs. R. McE. : Nearest of Kin. Harp., June.

Stuart, Mrs. R. McE.: Apollo Belvedere. Harp., Dec.

Stuart, Mrs. R. McE.: Mariah's Mourning and Other Half Hour Sketches. Harper \& Bros.

Stuart, Mrs. R. McE.: The Second Wooing of Salina Stue and Other Stories. Harper \& Bros.

Stuart, Mrs. R. McE.: Holly and Pizer and Other Stories. Harper \& Bros.

$$
\text { - } 1899
$$

Altsheler, J. A.: Black Feather's Throw. Lipp., Jan.

Bonsal, S.: The Way of the Cross. Harp., Mar.

Church, M.: Half Monin'. Cent., June.,

Davis, Mrs. M. E. M.: An Elephant's Track and Other Stories. Houghton, Mifflin \& Co.

Dunbar, P. L.: The End of the Chapter. Lipp., Apr. 
Dunbar, F. L.: The Strength of Gideon. Lipp., Oct. Edwards, H. S.: The Limerick Tigers. Cent., Jan. Edwards, H. S.: The Woodhaven Goat. Cent., Mar. Edwards, H. S.: Brother Sim's Mistake. Cent., Jul. Elliott, S. B.: Without the Courts. Harp., Mar.

Elliott, S. B.: Progress. McClure, Nov.

Elliott, S. B.: An Incident and Other Happenings. Harper \& Gibbs, G.: Hero Tales of Our Navy. J. B. Lippincott $\&$ Co.

Glasgow, E.: Between Two Shores. McClure, Feb.

Gordon, A. C.: Envion and Other Tales of Old and New Virginia. F. T. Neely \& Co., New York.

Hale, W. T.: The Backward Trail (Pioneer Stories). Cumberland Presbyterian Pub. House. Nashville, Tenn.

Harben, W. N.: The Convict's Return. Lipp., Apr.

Harris, J. C.: The Chronicles of Aunt Minervy Ann. Scrib.. Oct., 1899-June, 1900.

Harris, J. C.: Tales of the Home Folks. Chas. Scribner's Sons.

Harris, J. C.: Evening Tales. Chas. Scribner's Sons.

Harris, J. C.: Stories of Home Folks. Chas. Scribner's Sons. Harrison, Mrs. C. C.: A. Daughter of the South and Other Stories.

Kennedy, S. B.: Mistress Jessamine. L. H. J., Dec.

Kennedy, S. B.: The Coming of the Spirit. McClure, Sept. Kennedy, S. B.: The Governor's Last Levee. L. H. J., Nov. Murfree, M. N.: The Bushwhackers and Other Stories. Herbert S. Stone \& Co.

Rosebro, V.: Our Mantuamaker. Cent., May.

Smith, F. H.: The Boy in the Cloth Cap.

Stuart, Mrs. R. McE.: Minervy's Valentine. Harp., Feb.

Stuart, Mrs. R. McE.: Tobe Taylor's April Foolishness. Harp., May.

Stuart, Mrs. R. McE.: Uncle Still's Famous Weather Prediction. Cent., Jan.

Stuart, Mrs. R. McE.: Picayune. Lipp., Sept.

Thompson, M.: A Sunday Eclogue. Lipp., Sept.

Winston, A. S.: Miss Ophelia's Beat. Out., Oct. 7.

Young, M.: Aunt Cintly's Valentine. Cent., Jan. 
Supplementary List of Collections of Short Stories of Which the Dates of Publication Could Not Be Ascertained

Archer, G. W.: Tales of Texas. See Rutherford, p. III.

Augustine, G.: Legends of New Orleans. See Ruth., III; Manly, F. 459.

Cobb, J. B.: Mississippi Scenes. See Manly, p. 466.

Cloud, V. W.: See Lit. of So. Lit. vol. III, p. 979.

Hempstead, J. L.: After Many Days. (Stories.) Manly Ms. Henry, Mrs. I. M. P.: Roadside Stories. See Ruth., p. XV. Jett, J.: A Virginia Tragedy and Other Stories. Manly Ms. Langhorne, O. G.: Aunt Pokey's Son and Other Stories. See Ruth., p. XVIII.

Lanier, C. A.: Love and Loyalty at War, and Other Stories. Langborough, Mrs. M. W.: For Better or for Worse, and Other Stories.

Shortridge, Mrs. B. H.: Muggins and Other Stories. Manly Ms.

Sweet, A. E.: Three Dozen Good Stories from Texas Shiftings.

Williams, Mrs. M. B.: Tales and Legends of Louisiana. See Ruth., p. XXXII. 


\section{Bibliography}

Adams, Oscar Fay: A Dictionary of American Authors. Houghton, Mifflin \& Co., 1901.

Allibone, S. Austin: Dictionary of British and American Authors. J. B. Lippincott \& Co., 1871. Supplement. J. B. Lippincott \& Co., 1891.

Appleton's Cyclopœedia of American Biography. D. Appleton \& Co., 1894.

Baskervill, William Malone: Southern Writers. Pub. House M. E. Church South, Nashville, Tenn.

Davidson, James Wood: The Living Writers of the South. Carleton, New York, 1867.

Forrest, Mary: Women of the South Distinguished in Literature. Derby \& Jackson, New York, 1861.

Holladay, Carl: A History of Southern Literature. The Neale Pub. Co., New York and Washington, 1906.

Johnson, James Gibson: Southern Fiction Prior to 1860. The Michie Co., Charlottesville, Va., 1909.

Lamb's Biographical Dictionary of the United States. Boston, 1901.

Library of Southern Literature. 15 vols. The Martin \& Hoyt Co., New Orleans and Atlanta.

Link, Samuel Albert: Pioneers of Southern Literature. Pub. House M. E. Church South, Nashville, Tenn.

Manly, Louise: Southern Literature from 1579-1895. B. F. Johnston, Richmond, Va., 1900.

Manly Ms. (Notes and Clippings on Southern Literature, property of Louise Manly).

Minor, Benjamin Blake: The Southern Literary Messenger 1834-1864. The Neale Pub. Co., 1905.

Rogers E. Reinhold: Four Southern Magazines.

Rutherford, Milidred Lewis: The South in History and Literature. The Franklin Turner Co., Atlanta, Ga., 1907.

Tardy, Mrs. Mary T.: Southland Writers. Philadelphia, 1870. 
BIBLIOGRAPHY

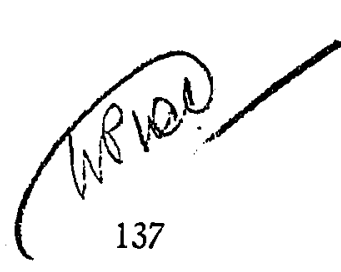

Tardy, Mrs. Mary T.: The Living Female Writers of the South, Philadelphia, 1872.

Trent, William P.: Southern Writers. The Macmillan Co., 1905.

Wauchope, George Armstrong: The Writers of South Carolina. Who's Who in America. A. N. Marquis \& Co., Chicago.

To the above works shouli be added the entire body of magazine literature touching upon Southern writers of the short story and upon aspects of Southern life and literature connected with the present theme. 